MÁRCIA MAZZEO GRANDE

\title{
A distribuição de automóveis novos em mudança? Estudo a partir de survey e pesquisa qualitativa em concessionárias
}




\section{Grande, Márcia Mazzeo}

A distribuição de automóveis novos em mudança? Estudo a partir de survey e pesquisa qualitativa em concessionárias / M.M. Grande. -- São Paulo, 2004.

$155 \mathrm{p}$.

Tese (Doutorado) - Escola Politécnica da Universidade de São Paulo. Departamento de Engenharia de Produção.

1.Automóveis novos (Distribuição) - Brasil 2.Varejo 3.Canais de distribuição I.Universidade de São Paulo. Escola Politécnica. Departamento de Engenharia de Produção Il.t. 
GRANDE, M. M. A distribuição de automóveis novos em mudança? Estudo a partir de survey e pesquisa qualitativa em concessionárias. 2004. $155 \mathrm{f}$. Tese (Doutorado) - Escola Politécnica, Universidade de São Paulo, São Paulo, 2004.

\section{ERRATA}

\begin{tabular}{|c|c|c|c|}
\hline Folha & Linha & Onde se lê & Leia-se \\
\hline 15 & 28 & automóveis comerciais & automóveis e comerciais \\
\hline 25 & 1 & lideres & líderes \\
\hline 26 & 24 & Para & Por \\
\hline 26 & 17 & GRONROOS & GRÖNROOS \\
\hline 29 & 25 & específica & específicos \\
\hline 35 & 1 & $\mathrm{e}$ & que \\
\hline 54 & 24 & fio & foi \\
\hline 64 & 32 & & F\&I 10 \\
\hline 70 & 5 & $\mathrm{e}$ & para \\
\hline 73 & 13 & ,2000, & (2000) \\
\hline 81 & 22 & contatos & contratos \\
\hline 85 & 8 & Estado em unidade & marca \\
\hline 91 & 12 & inovações & invasões \\
\hline 94 & 26 & $\mathrm{e}$ & é \\
\hline 105 & 7 & apresentarem & apresentaram \\
\hline 107 & 2 & feiras & feitas \\
\hline 119 & 1 & sucessida & sucedida \\
\hline 119 & 16 & capaciatação & capacitação \\
\hline 120 & 2 & termino & término \\
\hline 131 & 29 & infraestrutura & infra-estrutura \\
\hline 139 & 6 & ROSEMBLOON & ROSENBLOOM \\
\hline
\end{tabular}




\section{FOLHA DE APROVAÇÃo}

\section{Márcia Mazzeo Grande}

A distribuição de automóveis novos em mudança? Estudo a partir de survey e pesquisa qualitativa em concessionárias

Tese apresentada à Escola Politécnica da Universidade de São Paulo para obtenção do título de Doutor em Engenharia.

Área de Concentração: Produção

Aprovado em:

Banca Examinadora

Prof. Dr.

Instituição: Assinatura:

Prof. Dr.

Instituição: Assinatura:

Prof. Dr.

Instituição: Assinatura:

Prof. Dr.

Instituição: Assinatura:

Prof. Dr.

Instituição: Assinatura: 
DEDICATÓRIA

Para Álvaro e Abigail, com amor 


\section{AGRADECIMENTOS}

Ao professor Mário Sérgio Salerno pela orientação, apoio e compreensão durante a realização deste trabalho.

Aos professores Mauro Zilbovicius e Rosane Chicarelli Alcântara, pelas sugestões feitas no exame de qualificação.

À Associação Brasileira de Distribuidores Volkswagen (Assobrav), à Associação Brasileira dos Concessionários Chevrolet (Abrac), à Associação Brasileira dos Concessionários Renault (Abrare), a Associação Brasileira dos Distribuidores Toyota (Abradit) e à Federação Nacional de Distribuidores de Veículos (Fenabrave) pelas entrevistas e oportunidade de conhecer o setor de distribuição de automóveis novos no Brasil.

Aos proprietários e gerentes de concessionárias que concederam seu tempo para entrevistas e que muito gentilmente me receberam e responderam ao questionário, sem os quais não seria possível a realização desta pesquisa.

À secretária Lídia Nogueira da Silva e aos bibliotecários Vera e Ronni do Departamento de Produção da Escola Politécnica, sempre muito prestativos e atenciosos comigo.

Aos professores Alceu G. Alves Filho, Betty Antunes de Oliveira, José Roberto Ferro por terem contribuído de forma especial na minha formação.

Aos amigos Sayuri, Daniel e Pedro com quem compartilhei as angústias e as discussões sobre os textos. E a Eny, que muito me ajudou nos momento de dúvidas desta empreitada, e a Estela, que muito me incentivou.

Ao meu irmão Fernando e à Érica, pela presença constante, amizade, carinho e ajuda durante a redação do trabalho.

À minha tia Lúcia e à minha vó Alzira que com as suas preces me sustentaram e me tranquiilizaram durante a realização deste trabalho. 
E aos meus pais, Fábio e Maria Aparecida, pelo apoio, incentivo e exemplo de dedicação ao estudo. Sem as condições de estudo que eles me proporcionaram desde a minha infância, este trabalho não se concretizaria, a minha gratidão eterna.

Ao Álvaro, meu Alvaro, meu companheiro, que durante todos esses anos esteve sempre ao meu lado, compreendendo a minha ausência e me incentivando.

A Deus, acima de tudo. 


\section{RESUMO}

GRANDE, M. M. A distribuição de automóveis novos em mudança? Estudo a partir de survey e pesquisa qualitativa em concessionárias. 2004. $155 \mathrm{f}$. Tese (Doutorado) - Escola Politécnica, Universidade de São Paulo, São Paulo, 2004.

Esse trabalho teve por objetivo analisar as mudanças que estão ocorrendo nos canais de distribuição de carros novos no Brasil, especificamente no que concerne à constituição de novos formatos de negócio no varejo de automóveis novos e à relação com as montadoras. $\mathrm{O}$ sistema de distribuição de carros novos baseado em redes de revendedores exclusivos e independentes de cada marca/montadora que integra em um só lugar as funções de vendas de carros novos, vendas de carros usados, distribuição de pecas de reposição, assistência técnica e reparo e financiamento entrou na pauta da indústria automotiva na última década, devido ao aumento da concorrência e à ineficiência do sistema em atender as expectativas dos consumidores em termos de qualidade de serviços e preços. No Brasil, várias discussões sobre uma reestruturação das redes de distribuição e do formato de negócio da revenda estão em andamento desde o início dos anos 2000. Este estudo, realizado através de entrevistas e de um survey em concessionárias, levantou que as concessionárias estão terceirizando parte dos seus serviços de assistência técnica e reparo e obtendo ganhos em termos de rapidez, qualidade dos serviços e redução de custos, bem como adotando algumas novas práticas de gestão e tecnologias da informação. Apurou-se também que montadoras estão aumentando o controle sobre a produção de serviços das concessionárias através de exigências de padronização de lojas e processos de atendimento.

Palavras-chave: distribuição de carros, canais de distribuição, carros novos, varejo 


\begin{abstract}
GRANDE, M. M. The distribution of new automobiles is changing? Study carried out from a survey and qualitative research in dealers franchise. 2004. 155p. Thesis

(Doctoral) - Escola Politécnica, Universidade de São Paulo, São Paulo, 2004.
\end{abstract}

The objective of this work is to analyze the changes that are occurring in the distribution channels of new cars in Brazil, more specifically concerning the constitution of new retailing business format and its relation with the car manufactures. The distribution system based on exclusive and independent franchise dealership of each brand/manufacturer that integrates in the same place the functions of new cars sales, used cars sales, spare parts supply, services and financing, has being taken into consideration in the automobile industry since the last decade. This was due to the increase in competition and the inefficiency of the system to match the expectations of the consumer in terms of quality of services and prices. In Brazil several discussions about distribution network restructuring and retailing business form are being carried out since the beginning of 2000. This study, made through interviews and survey in car retailers, has found out that the dealers are outsourcing part of their support and repair services and with that procedure gaining in quality of services, time and cost reduction as well as adopting new managing practices and new technological information. Also it has been found out that the car manufactures are increasing the control on services production of the dealers through the requirement of standardization of the shops and sales and services processes.

Keywords: car distribution, distribution channels, new car, retail 


\section{LISTA DE TABELAS}

Tabela 2.1- Tabela 2.1- Origem dos ganhos das revendas nos Estados Unidos em 2002

Tabela 2.2- Origem das margens de lucro das revendas em países europeus em 1994.46

Tabela 2.3- Porte das concessionárias segundo o número de carros novos comercializados por mês.

Tabela 2.4- Percentual de faturamento das vendas de autos e comerciais leves por porte das concessionárias

Tabela 2.5- Origem dos lucros das revendas no Brasil em 2001.

Tabela 3.1- Participação da marcas nos Estados de São Paulo, Rio de Janeiro e

Paraná em maio de 2004.

Tabela 3.2- Distribuição do número de concessionárias por estado em unidades. 85

Tabela 4.1- Distribuição das concessionárias por marca. 97

Tabela 4.2- Negócios associados. 98

Tabela 4.3- Volume de carros novos comercializados por mês. 98

Tabela 4.4- Número de atendimentos na oficina por mês. 99

Tabela 4.5- Porte das revendas quanto ao número de funcionários. 99

Tabela 4.6- Origem do lucro das revendas 100

Tabela 4.7- Rentabilidade do negócio 101

Tabela 4.8- Comercialização de carros novos. 102

Tabela 4.9- Formatos de negócio. 102

Tabela 4.10- Aspectos gerais das terceirizações. 104

Tabela 4.11- Aspectos que envolvem a relação com a montadora. 107

Tabela 4.12- Exigências das montadoras. 110

Tabela 4.13- Serviços oferecidos pelos sites das revendas na Internet 113

Tabela 4.14- Grau de informatização dos processos nas revendas. 114

Tabela 4.15- Adoção de novas práticas de gestão. 115

Tabela 4.16- Serviços oferecidos pelas revendas. 118

Tabela 4.17- Visão dos concessionários sobre o comércio-eletrônico de carros das montadoras 


\section{LISTA DE GRÁFICOS}

Gráfico 2.1 - Fontes de lucro bruto da indústria automotiva na Europa em 2000..... 51

Gráfico 2.2 - Vendas de automóveis novos no Brasil................................................. 68

Gráfico 3.1 - Distribuição dos concessionários por Estado..................................... 85

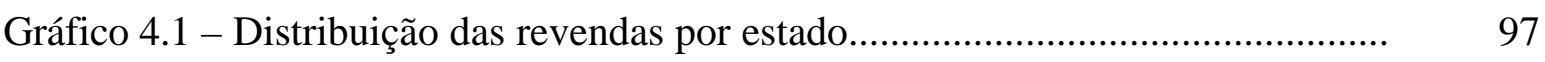

Gráfico 4.2 - Produtividade em função do número de funcionários.......................... 100

Gráfico 4.3 - Benefícios obtidos com a terceirização ............................................ 105

Gráfico 4.4 - Incentivos da montadora para o cumprimento das exigências ............. 111

Gráfico 4.5 - Tecnologias da informação utilizadas pelas revendas.......................... 113

Gráfico 4.6 - Formas alternativas de vendas........................................................ 117

Gráfico 4.7 - Principais concorrentes das redes de concessionárias......................... 120

Gráfico 4.8 - Prioridades das revendas................................................................ 124 


\section{SUMÁRIO}

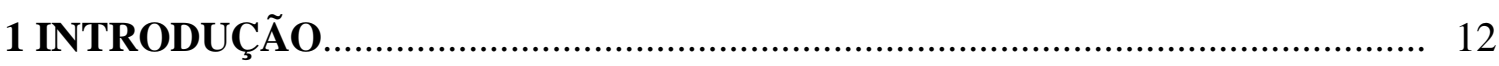

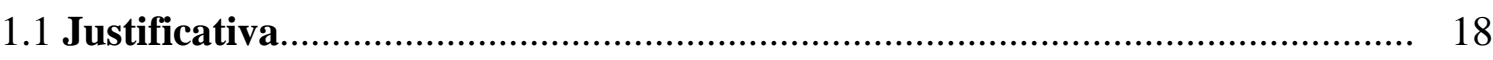

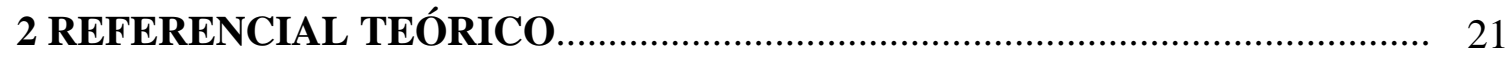

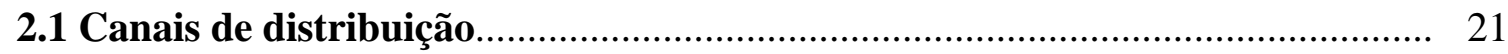

2.1.1 Conceitos, agentes, funções e estrutura............................................................ 21

2.1.2 Fatores determinantes para a estrutura do canal de distribuição........................... 25

2.1.3 Estratégias de distribuição............................................................................ 31

2.1.4 Gerenciando o relacionamento no canal..................................................... 32

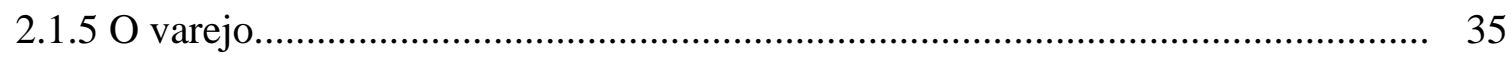

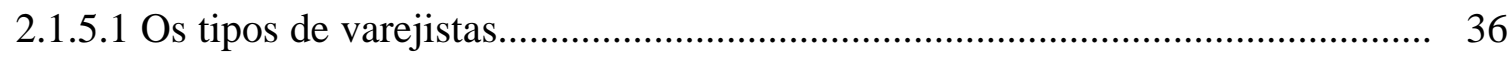

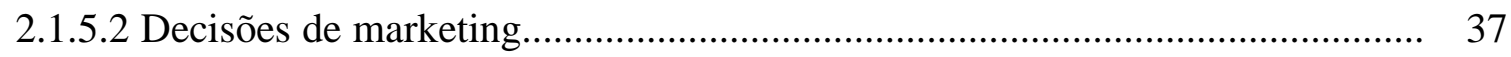

2.1.5.3 Tendências no varejo............................................................................... 38

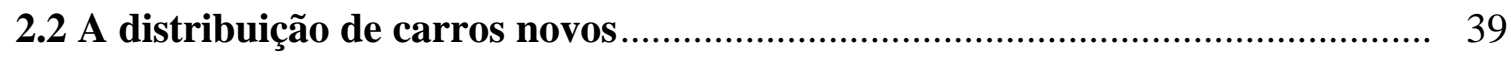

2.2.1 A distribuição de veículos nos Estados Unidos, Europa e no Japão..................... 41

2.2.1.1 A distribuição de veículos nos Estados Unidos.............................................. 41

2.2.1.2 A distribuição de veículos na Europa............................................................... 45

2.2.1.3 A distribuição de veículos no Japão................................................................ 48

2.2.2 A crise no sistema de distribuição de carros novos........................................... 50

2.2.2.1 A reação do varejo........................................................................................ 53

2.2.2.2 A reação das montadoras........................................................................... 55

2.2.3 A proposta de reestruturação da distribuição....................................................... 60

2.2.4 A distribuição de carros novos no Brasil........................................................... 62

2.2.4.1 O histórico e a regulamentação de veículos no Brasil....................................... 65

2.2.4.2 A situação das redes de distribuição de carros novos no Brasil......................... 68

2.2.4.3 Mudanças em curso da distribuição de carros novos no Brasil......................... 72

3 MÉTODO E PROCEDIMENTOS DE PESQUISA........................................ 77

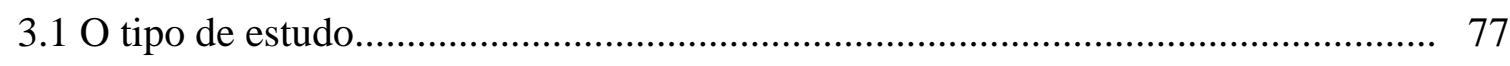

3.2 A formulação das proposições.................................................................. 78

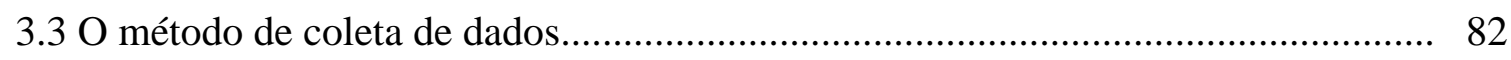


3.3.1 A amostra das empresas................................................................................ 84

3.3.2 $\mathrm{O}$ instrumento de pesquisa....................................................................... 86

3.4 Análise dos resultados.............................................................................. 88

3.5 Limitações do estudo................................................................................. 88

4 ANÁLISE DA PESQUISA DE CAMPO_......................................................... 90

4.1 Descrição das redes de distribuidores.................................................................. 90

4.2 Resultados dos questionários........................................................................... 96

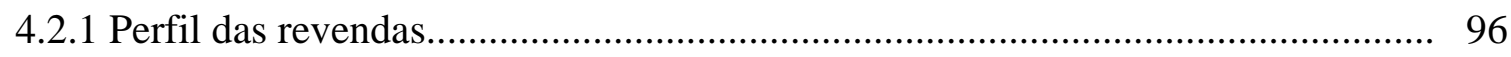

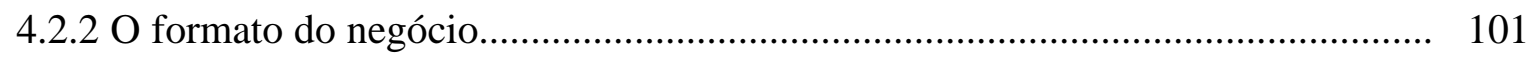

4.2.3 Relação concessionária - montadora..................................................................... 106

4.2.4 Inovação nas revendas.................................................................................. 112

4.2.3 Sobre o negócio............................................................................................ 119

5 CONCLUSÃO

5.1 Sugestões para pesquisas posteriores.................................................................. 133

REFERÊNCIAS BIBLIOGRÁFICAS ............................................................. 134

ANEXO 1 - Roteiros das entrevistas.................................................................. 141

ANEXO 2 - Questionário 


\section{INTRODUÇÃO}

Até meados da década de 1990, as atenções dos produtores se voltavam a montante da cadeia. Buscava-se o desenvolvimento de fornecedores, com o objetivo de obter redução de custos e qualidade para os componentes e serviços necessários para a consecução da produção. As atividades a jusante da cadeia estavam, então, relegadas a segundo plano. No entanto, nos últimos anos, com o aumento da competitividade, tem-se observado um interesse cada vez maior das empresas pelas atividades a jusante da cadeia produtiva e grande atenção tem sido dada às questões relativas à distribuição de bens e serviços, especialmente à escolha e gestão dos canais de distribuição.

Para Narus e Anderson (1996) o interesse dos fabricantes pelos canais de distribuição se deve a dois fatores principais. Em primeiro lugar, as tecnologias estão disponíveis para todos os concorrentes; em segundo lugar, os produtos estão cada vez mais parecidos com níveis similares de qualidade e incorporando cada vez mais serviços. Assim, cada vez mais as empresas estão reconhecendo que os canais de distribuição representam uma inexplorada oportunidade na busca de redução de custos e aumento de produtividade.

Além desses fatores, um outro aspecto que tem chamado a atenção é a mudança gradativa do foco de poder dentro dos canais de distribuição. Lentamente o poder está saindo das mãos dos fabricantes e migrando para os varejistas (KUMAR, 1996; STERN; EL-ANSARY; COUGHLAN, 1996; ANDERSON; DAY; RANGAN, 1997). Anderson, Day e Rangan (1997) sugerem que a crescente concentração que vem ocorrendo no varejo em geral e a emergência dos mercados de massa têm colocado os varejistas como condutores do processo. Dessa forma, o interesse dos produtores por novas estruturas de canais, bem como por novas formas de gestão dos canais de distribuição, pode ser visto como uma oportunidade de reequilibrar sua força frente à concentração no varejo (STERN; EL-ANSARY; COUGHLAN, 1996). Por exemplo, muitos fabricantes estão encurtando seus canais de distribuição e vendendo diretamente seus produtos através da Internet, de catálogos e de lojas próprias, assumindo uma função antes relegada aos seus distribuidores (KUMAR, 1996).

Desenhar, desenvolver e manter relacionamentos efetivos entre os membros do canal de distribuição, que melhorem a coordenação entre os diferentes elos da cadeia produtiva, 
tornou-se uma questão importante para as empresas que desejam alcançar vantagens competitivas sustentáveis (STERN; EL-ANSARY; COUGHLAN 1996).

Para vários autores (SILVA; ALCÂNTARA, 2001; NARUS; ANDERSON, 1996; WISE; BAUMGARTNER, 1999; KUMAR, 1996), as empresas que obterão vantagem competitiva sustentável serão aquelas que explorarão formas mais cooperativas de relacionamento no canal, com formação de parcerias e alianças estratégicas, e procurarão explorar novas estruturas de canais com diferentes níveis de serviços para atingir diferentes segmentos de consumidores (WISE; BAUMGARTNER, 1999; NARUS; ANDERSON, 1996; ANDERSON; DAY; RANGAN, 1997).

A estrutura de canais de distribuição é função de uma série de fatores como os custos de transação, o ambiente institucional, as tecnologias, as estratégias empresariais, os fatores culturais e históricos bem como o nível de serviço oferecido (STERN; EL-ANSARY; COUGHLAN, 1996). Os canais de distribuição evoluem continuamente no tempo, alterando e/ou ajustando suas funções, para se adequarem às novas condições do ambiente. Para manter suas posições competitivas, os membros do canal podem se especializar naquelas funções que desempenham de forma mais eficiente, repassando as outras funções para outros agentes do canal. Essas adaptações impactam toda a organização do canal e acabam por promover uma nova divisão do trabalho dentro do canal de distribuição (STERN; EL-ANSARY; COUGHLAN, 1996; KOTLER, 2000).

Mudanças nos canais de distribuição podem ser causadas, segundo argumentam Kotler (2000), Stern, El Ansary e Coughlan (1996), Alcântara (1997) e Dias (1993), por alterações no mercado (expansão, retração, entrada de novos concorrentes), na própria distribuição, na legislação, na economia (distribuição de renda, disponibilidade de financiamentos, estabilidade da moeda), se o produto atinge seu estágio de maturação e mudanças tecnológicas (especialmente das tecnologias da informação).

Tais aspectos não podem ser ignorados ao se tratar da indústria automobilística. Grosso modo, o sistema de distribuição de veículos ocorre através de redes de franquias independentes e exclusivas de cada marca que integram, num mesmo lugar, as funções de vendas de carros novos, vendas de carros usados, distribuição de peças de reposição, serviços de assistência técnica e financiamento. 
Como em outros setores, a distribuição de automóveis novos foi uma questão ignorada até meados da década de 1990. Até então, a atenção da indústria automotiva estava centrada na adoção de novos modelos de produção, na melhoria da qualidade de processos de produção e produtos, na redução de custos, no processo de desenvolvimento de novos produtos e na relação com os fornecedores.

Parte do desinteresse pode ser explicada pela demanda maior que a oferta de veículos. Assim, os problemas concernentes à distribuição, como custo, ineficiência, qualidade do serviço etc, ficavam em segundo plano, uma vez que eram absorvidos em função do excesso de demanda (CHANARON; JULLIEN, 1999).

No entanto, a partir de meados de 1990, mudanças nos principais mercados mundiais colocaram a questão da distribuição na pauta da indústria automobilística. Entre eles estão a intensificação da competição, devido ao surgimento de um maior número de marcas, o que altera o comportamento do consumidor em relação à lealdade pela marca e à retração da demanda de carros novos (MERCER, 1994; CHANARON; JULLIEN, 1999; HALTZFELD, 1998,); e ao surgimento de novos atores, como as cadeias especializadas em serviços de manutenção, que oferecem serviços antes exclusivos das redes de franquias (MERCER, 1994; HOFFMEISTER, 1995; HATZFELD, 1998; CHANARON; JULLIEN, 1999); e aos sites automotivos, possibilitados pelos avanços das tecnologias da informação, que além de viabilizarem um outro canal de venda, disponibilizam uma enorme quantidade de informação para o consumidor, aumentando a sua participação e poder no processo de compra do veículo (NISHIMURA; MORITA, 2002).

O sistema tem se mostrado ineficiente no atendimento às expectativas dos clientes, em termos de qualidade e custos dos serviços prestados, gerando insatisfação nos consumidores (MERCER, 1994; CHANARON; JULLIEN, 1999; NISHIMURA; MORITA, 2002). Além disso, a retração do mercado e o aumento da confiabilidade dos veículos que se reflete na menor necessidade de manutenção sugerem que não há mais escala suficiente no nível de cada revenda para suportar todas as funções num só lugar; fato esse que, na visão de Mercer (1994) e Chanaron e Jullien (1999), coloca em xeque os princípios básicos do sistema atual de distribuição de carros novos: a exclusividade de marca e a integração de funções. 
Vários autores argumentam que, para manter sua lucratividade, as montadoras terão de alterar e/ou melhorar os seus sistemas de distribuição (MERCER, 1994; CHANARON; JULLIEN, 1999; BUZZAVO; VOLPATO, 2001; BOHMAN; ROSENBERG; STENBRINK, 2003; KNUPFER; RICHMOND; ARK, 2003), o que passaria pela melhoria da imagem desgastada das revendas junto ao consumidor final, por uma mudança nas relações entre montadoras e suas respectivas redes de distribuição, tradicionalmente conflituosas, buscando formas de relacionamento mais cooperativas e por uma especialização dos revendedores através da desagregação de suas funções.

No Brasil, a distribuição de veículos novos dá-se através das redes de concessionárias independentes e exclusivas de cada marca, que integram um só lugar a venda de carros novos, venda de carros usados, reposição de peças e serviços de assistência técnica e financiamento.

Até 2000, a rede de concessionárias era o único canal de distribuição de carros novos no Brasil, quando a GM inovou e introduziu um outro canal, vendendo o Celta diretamente para o consumidor final através da Internet. Atualmente, das oito montadoras instaladas no Brasil, somente a Toyota e a Honda não utilizam esse canal. No entanto, a rede de concessionárias é responsável pela maior parte do volume de carros novos vendidos no país e é nela que grande parte das vendas iniciadas pela Internet se concretiza. Além disso, as concessionárias são os canais de entrega e de serviços dos produtos vendidos pelas montadoras ao consumidor final através da Internet.

Considerando somente as redes de concessionárias de automóveis novos, há cerca de 2200 concessionárias, em sua maioria pequenas e médias empresas de atuação local. Segundo a Federação Nacional da Distribuição de Veículos Automotores (FENABRAVE) a venda de carros novos foi, e ainda é, a principal fonte de lucro das concessionárias. Segundo a Fenabrave, estima-se que o faturamento do setor de distribuição relativo ao segmento de automóveis comerciais leves em 2002 tenha sido de R\$ 49,20 bilhões, incluindo veículos novos, veículos usados, peças e serviços.

Assim como nos Estados Unidos e na Europa, o relacionamento entre as montadoras e as suas respectivas redes de concessionárias no Brasil é marcado pelo conflito (MAIA, 2000; ARBIX; VEIGA, 2001). As montadoras impõem certas condições no tocante ao cumprimento de cotas de veículos, compra mínima de peças, estrutura física, ferramental de oficina etc. 
Em meados da década de 1990, a demanda era maior que a oferta, a prática do ágio era institucionalizada e houve um período em que o carro usado chegou a valer mais que o novo. Era também prática corrente no setor revender carros novos para garagistas. Naquela época, esse tipo de negócio era vantajoso: obtinha-se boas margens de lucro com a operação e os concessionários conseguiam se desfazer de produtos de baixa demanda que eram impostos pelas montadoras. Desde o final da década de 1990, o setor de distribuição de automóveis novos no Brasil vem passando por transformação. Houve queda de demanda de carros novos devido à pressão sobre preço dos carros novos, renda média do brasileiro estagnada, que reduziu seu poder de compra, e altas taxas de juros para compra de veículos. Houve ainda a entrada de novas marcas, competindo por um mercado antes dividido entre quatro montadoras.

As redes de concessionárias enfrentam problemas financeiros. Devido ao aumento da concorrência no mercado de automóveis no país, as redes de concessionárias têm sido pressionadas para reduzirem as margens de lucro na comercialização de carros novos, sua principal fonte de receita (ALMEIDA, 2000). Além disso, o nível de conflito horizontal na rede é alto: existe muita competição entre as revendas da mesma marca, o que acaba aprofundando a descapitalização das pequenas e médias revendas (ARBIX; VEIGA, 2001). Junta-se a isso o fato de que os concessionários sofrem forte concorrência das oficinas e do setor de reposição independentes. Segundo Arbix e Veiga (2001) a rentabilidade do setor vem diminuindo e já atingiu índices inferiores ao da própria cadeia automotiva.

Um estudo realizado por Urdan e Zuñiga (2001) apontou também a dificuldade das concessionárias de assimilarem competências gerenciais, capazes de criar satisfação nos clientes com os serviços oferecidos; fato esse que reflete diretamente na lealdade do consumidor ao fabricante do veículo e na fidelidade ao prestador de serviços. Esse é um aspecto importante, visto que no sistema atual de distribuição a concessionária é o elo da cadeia mais próximo do consumidor final e é nela que ganhos e perdas de mercado são obtidos.

A tensão nas redes das maiores montadoras é grande. Desde o início da década de 2000, vem se observando um processo de redução do número de concessionárias e de concentração de capital. O processo de concentração tem se dado através da compra de pequenos 
concessionários pelas grandes revendas. (O GLOBO, 26/03/2000; HESSEL; VILARDAGA, 2000; ALMEIDA, 2000). Em alguns casos, ele é estimulado pela própria montadora. Não há registros de quantas concessionárias fecharam desde o início da década, assim como nenhuma entidade que representada o setor informa quantos grupos detêm atualmente a distribuição no país.

Desde dos anos 2000 discute-se, de um lado, a possibilidade de novos formatos de estruturação da rede, com formação de parcerias entre as concessionárias de uma mesma marca, para se obter redução de custos, ganho de escala e, assim, recuperar a rentabilidade (NOVOS..., 2001; ARBIX; VEIGA, 2001; ASSOCIAÇÕES..., 2002). De outro lado, fala-se também na necessidade das revendas recomporem seus ganhos com atividades antes consideradas secundarias como: venda de carros usados, serviços de oficinas, venda de peças de reposição e oferta de serviços que agreguem valor ao negócio da revenda. Porém, nada de conclusivo foi apontado.

Esta tese começou a se desenhar a partir de um levantamento preliminar de dados realizado junto a concessionárias e associações representativas do setor, quando se detectaram mudanças na forma como as revendas estão operando suas funções, especialmente no que se refere à assistência técnica e reparo, na administração do negócio e na relação com a montadora. A partir dessa observação inicial, verificou-se a necessidade de aprofundar a compreensão sobre a distribuição de carros novos no Brasil e de realizar análises sobre essas mudanças.

Assim, este trabalho tem por objetivo analisar as mudanças que estão ocorrendo nos canais de distribuição de carros novos no Brasil, especificamente no que concerne à formação de novos formatos de negócio no varejo de automóveis novos e à relação com as montadoras.

Os objetivos específicos estabelecidos foram:

- Identificar e caracterizar os formatos de varejo de automóveis novos;

- Verificar o estágio de adoção de novas práticas de gestão e o uso de tecnologias da informação nas concessionárias;

- Identificar quais mudanças estão ocorrendo no relacionamento entre montadoras e rede de distribuidores. 
Trata-se de um estudo exploratório realizado através de um survey junto às redes de concessionárias de 7 montadoras instaladas no Brasil, dos estados de São Paulo, Rio de Janeiro e Paraná, e de entrevistas com concessionárias e entidades representativas do setor.

As proposições estão fundamentadas na teoria sobre canais de distribuição e nas discussões sobre a problemática de distribuição de veículos nos Estados Unidos e Europa.

P1: As concessionárias de automóveis novos no Brasil estão se reestruturando, buscando terceirizar algumas de suas funções ou compartilhar recursos a fim de recuperarem suas margens e rentabilidade.

P2: Está havendo uma mudança no padrão de relacionamento entre montadora e rede de distribuição no sentido de construir relacionamentos mais cooperativos.

P3: As concessionárias de automóveis novos no Brasil estão inovando através da adoção de novas práticas de gestão, da utilização das tecnologias da informação e ampliação dos serviços oferecidos aos clientes.

\subsection{Justificativa}

Nos últimos anos, com o aumento da competitividade, a concorrência vem deixando de acontecer entre empresas isoladas para ocorrer entre as cadeias de suprimentos. A abordagem do Supply Chain Management (Gestão da Cadeia de Suprimentos) diz que é possível construir vantagens competitivas sustentáveis integrando todas as atividades da cadeia produtiva, mediante a melhoria do relacionamento e do planejamento conjunto entre os vários elos da cadeia produtiva (HANDFIELD; NICHOLS, 1999), o que envolve também as atividades a jusante da cadeia produtiva como a escolha e a gestão de canais de distribuição.

Silva e Alcântara (2001) apontam que existe uma relação entre a capacidade de uma empresa de responder rapidamente às oportunidades de negócio e a sua capacidade de coordenação entre as atividades de produção e de distribuição desenvolvidas pelas empresas ao longo dos canais de distribuição. Dessa forma, as decisões referentes à escolha e gestão dos canais de distribuição, responsáveis por tornarem os produtos e os serviços disponíveis para o consumidor, começaram a ser consideradas importantes dentro das estratégias empresariais 
(STERN; EL-ANSARY; COUGHLAN, 1996; WISE; BAUMGARTNER,1999). Vistos agora como uma extensão do negócio das empresas, os canais de distribuição devem ter um papel fundamental no desenvolvimento de novos produtos e serviços (KOTLER, 2000; FITES, 1996) e na coordenação da cadeia produtiva a montante, além de permitir que as empresas explorem novos arranjos para trabalharem juntas de forma mais cooperativa e obterem maiores ganhos (NARUS; ANDERSON, 1996).

Assim, o estudo dos canais de distribuição, enquanto variável estratégica, dos fatores que alteram sua estrutura e das formas de relacionamento indústria - distribuidores, tem aumentado de importância nos últimos anos.

Os estudos referentes à distribuição de veículos, especificamente sobre estrutura e gestão dos canais de distribuição, são poucos e estavam, até o início dos anos 2000, praticamente restritos às publicações de consultorias. Alguns deles (MERCER, 1994, 1997; HIRSH, 1999) apresentam as limitações do sistema de distribuição baseados nas redes de franquias independentes e exclusivas de cada marca e trazem sugestões para que certas deficiências sejam solucionadas.

Outros estudos, de cunho mais acadêmico, como os de Chanaron e Jullien (1999) e Buzzavo e Volpato (2001), traçam possíveis cenários para o futuro da distribuição de carros novos. No entanto, carecem de uma base empírica de dados. Apenas o de Buzzavo e Volpato (2001) traz um estudo exploratório, realizado através um survey, sobre a performance das redes de distribuição na Itália. Mais recentemente Nishimura e Morita (2002) apresentam um estudo comparativo sobre o impacto das tecnologias da informação na distribuição de carros no Japão e nos Estados Unidos e da possibilidade de sobrevivência de certos padrões de estratégia na distribuição de veículos nos dois países. A conclusão a que os autores chegam é que não deve existir no futuro próximo um padrão dominante e que diferentes formatos de varejo de carros novos devem coexistir.

No Brasil, as pesquisas na indústria automobilística enfatizam principalmente a produção e a relação com fornecedores. Existem poucos estudos sobre projeto e, no caso da distribuição, as pesquisas são praticamente inexistentes. Dentre as publicações sobre o assunto estão as de Almeida (2000) e Urdan e Zuñiga (2001). 
Almeida (2000) traz um balanço sobre a situação das redes de concessionárias em relação ao início do comércio-eletrônico de carro novos e apresenta as perspectivas para o setor. Porém, não apresenta uma base sólida de dados. Urdan e Zuñiga (2001), fazem um estudo empírico e apontam que há uma relação entre a satisfação do cliente com os serviços de assistência técnica e a lealdade ao fabricante de veículos. Há, portanto uma lacuna de estudos acadêmicos para abordar a forma como as concessionárias operam suas funções e o relacionamento entre montadoras e distribuidores. As informações sobre o assunto vêm principalmente de artigos na mídia e dos boletins das entidades representativas do setor. Este estudo deve, portanto, contribuir para o aprofundamento do conhecimento sobre como se processa a distribuição de carros novos no país através do levantamento de uma base de dados sólida sobre o assunto junto às redes de distribuição e deve esclarecer aspectos sobre a operação das revendas e do relacionamento com as montadoras no Brasil. Especificamente para as concessionárias, alguns resultados deste trabalho podem servir para que elas avaliem o conjunto de ações que compõem suas estratégias competitivas e de produção de serviços.

Além da falta de publicações no Brasil, outros dois aspectos tornam interessante e justificam uma investigação sobre as mudanças que estão ocorrendo nos canais de distribuição de carros novos. Em primeiro lugar, tem-se no Brasil uma situação especial: a presença de novos entrantes - montadoras que se instalaram na última década no país, para conquistar espaço no mercado, elas devem tentar inovar em alguns aspectos relativos à distribuição. Segundo, tratase de um assunto contemporâneo, que envolve muitos aspectos a serem esclarecidos, como por exemplo, a efetividade das vendas diretas pelas montadoras, a conveniência ou não de se manter vendas e serviços juntos, etc.

Esta tese está estruturada em 5 capítulos, incluindo essa introdução. O capítulo 2 apresenta o referencial teórico que engloba canais de distribuição e distribuição de veículos. O capítulo 3 descreve o tipo de estudo realizado, traz os detalhes do trabalho de campo, desde o levantamento preliminar dos dados para a elaboração de um questionário, até o acompanhamento da devolução dos mesmos, e discute as vantagens e desvantagens do método empregado. O capítulo 4 apresenta os resultados obtidos e as discussões e, no capítulo 5, são apresentadas as conclusões do estudo e é proposto um direcionamento para pesquisas futuras. 


\section{REFERENCIAL TEÓRICO}

Este capítulo apresenta o referencial teórico da tese e está dividido em duas partes. A primeira aborda os canais de distribuição apresentando seus conceitos, funções, estrutura e relacionamento no canal. A segunda parte trata da distribuição de veículos novos enfocando a origem do sistema de redes de franquias exclusivas de cada marca, a regulamentação da distribuição, a crise do sistema, a reação das montadoras e as propostas de reestruturação do sistema.

\subsection{Canais de distribuição}

A distribuição envolve basicamente duas áreas de decisão: a distribuição física e os canais de distribuição. Na distribuição física são consideradas as decisões sobre transporte, armazenagem e distribuição, ou seja, toda a parte logística que envolve o produto. Nos canais de distribuição consideram-se as decisões referentes aos caminhos que os produtos devem seguir até chegar no consumidor, por exemplo, usar um varejista ou vender diretamente para o consumidor final (LAS CASAS, 2004).

Segundo Kotler (1996) as decisões sobre distribuição, especialmente as relativas à escolha e administração dos canais de distribuição, interferem em todas as outras decisões de marketing e naquelas referentes à estratégia competitiva da empresa. O preço praticado, por exemplo, depende da decisão de se utilizar o varejo de massa ou lojas especializadas.

O escopo deste trabalho é o estudo dos canais de distribuição de carros novos no Brasil e serão tratados, a seguir, aspectos gerais referentes ao projeto e à administração dos canais de distribuição.

\subsubsection{Conceito, agentes, funções e estrutura}

De acordo com Stern, El-Ansary e Coughlan (1996, p. 1), canais de distribuição são "um conjunto de organizações interdependentes envolvidas no processo de tornar os produtos e serviços disponíveis para o consumo ou uso". Suas funções vão além de colocar os produtos e serviços no lugar certo com quantidade, qualidade e preço adequados para satisfazer uma 
demanda existente. Eles devem também estimular a demanda realizando atividades promocionais.

Stern, El-Ansary e Coughlan (1996), Kotler (2000) e Churchill e Peter (2000), Bowersox e Cooper (1992) advogam que o uso de intermediários no processo de distribuição é justificado por razões econômicas, pois através de suas especializações, contatos e escala de operações, os intermediários oferecem aos produtores vantagens que eles não poderiam conseguir sozinhos. Entre os motivos apontados por esses autores estão:

- O aumento da eficiência do processo de troca através da redução do número de transações;

- A redução da distância entre a variedade de mercadorias e serviços oferecida pelo fabricante (grande quantidade e baixa variedade) e a demanda dos consumidores (quantidade limitada e grande variedade);

- A rotinização da transação: refere-se à escolha de conjunto de agentes e o estabelecimento de relacionamentos de longo prazo, o que permite a construção de um histórico de transações, com base em normas pré-estabelecidas, evitando a necessidade de negociações a cada nova transação, o que pode reduzir os custos da distribuição;

- A facilitação do processo de busca: o processo de busca envolve incertezas porque os produtores não estão certos das necessidades dos consumidores e estes, por sua vez, não têm certeza de que vão encontrar o que desejam. Assim, atacadistas e varejistas se organizam em segmentos como drogarias, supermercados etc., e os produtos podem ser encontrados em vários pontos de vendas.

- A especialização: cada agente do canal pode desempenhar tarefas específicas a um custo unitário menor em função da economia de escala alcançada e, assim, obter uma maior eficiência na performance do canal como um todo.

Bowersox e Cooper (1992) classificam os agentes do canal de distribuição em a) primários e b) facilitadores ou especializados. Os agentes primários: são os que adquirem e gerenciam estoques, assumem parte dos riscos a eles associados e negociam os produtos. São eles os produtores, os atacadistas e os varejistas. Os produtores criam e/ou manufaturam os produtos e são considerados os originadores do canal. $\mathrm{O}$ atacado engloba as atividades relacionadas à venda de produtos ou serviços para aqueles que compram com o objetivo de uso industrial ou para revenda. Eles facilitam o trabalho dos fabricantes fornecendo aos varejistas variedade e 
quantidade dos produtos desejados. O varejo engloba as atividades de vendas de produtos e serviços ao consumidor final. É o ponto final do processo de distribuição, reunindo uma grande variedade de produtos de diversas fontes de suprimento. (KOTLER, 2000).

Os agentes facilitadores ou especializados são as empresas que prestam serviços e que são essenciais ao funcionamento do canal, mas não assumem a propriedade dos estoques. São eles as instituições financeiras, as companhias de seguros, os operadores logísticos entre outros.

As funções desempenhadas pelos membros do canal podem ser agrupadas em fluxo para frente, fluxo combinado e fluxo para trás. Os fluxos referentes à posse física, promoção e propriedade formam o fluxo para frente, ou seja, partem do produtor para o consumidor final. O financiamento, informação e risco e negociação formam os fluxos combinados. Pagamento e pedidos formam o fluxo para trás, isto é, vão dos consumidores às empresas produtoras.

Há casos em que algumas funções são exclusivas dos fabricantes. Em outros há necessidade de que algumas delas sejam desempenhadas em conjunto pelo fabricante e pelo distribuidor ou mesmo distribuídas entre os vários membros do canal. Exemplo disso é a situação em que todos os membros do canal são responsáveis pela estocagem do produto. Essa duplicação de funções pode ser necessária para garantir que os consumidores terão os produtos desejados na quantidade, local e tempo necessários. Isso, no entanto, aumenta os custos da distribuição. Quando esses custos se tornam injustificáveis, a redundância se torna ineficiente.

As funções também devem ser sincronizadas. Dessa forma, o lançamento de um produto pode fracassar se as funções de posse física e promoção não estiverem em sintonia. A coordenação das funções ocorre através do fluxo de informação entre os membros do canal.

Todas as funções e fluxos do canal de distribuição são indispensáveis, a questão é quem as realizará. Assim, Stern, El-Ansary e Coughlan (1996) estabeleceram, com relação a essas funções, três princípios básicos que devem ser levados em consideração na estruturação de um canal de distribuição:

- Pode-se eliminar ou substituir organizações que pertençam ao canal;

- As funções que essas organizações desempenham não podem ser eliminadas;

- Quando organizações são eliminadas, suas funções devem ser assumidas por outros membros do canal. 
De acordo como número de unidades intermediárias, os canais podem ser diretos, semidiretos e indiretos. Quando existe somente um elo entre o produtor e o consumidor tem-se um canal direto de distribuição. Seus principais tipos são a venda por loja de fabricante, vendas por televisão, vendas de porta em porta, telemarketing. Nesses casos, o desempenho das funções concernente ao canal é de responsabilidade do produtor ou do consumidor. Em outros casos, o canal é constituído pelo fabricante e por um ou mais intermediários - atacadistas e/ou varejistas. São os chamados canais indiretos de distribuição.

A partir da perspectiva do fabricante, quanto maior o número de unidades intermediárias mais difícil é a atuação do fabricante sobre o canal e menores são as chances dele conseguir informações fidedignas e de qualidade sobre os consumidores finais. Porém, o produtor pode obter maior ou menor controle sobre o canal de distribuição dependendo do tipo de contrato firmado entre as partes.

Segundo o grau de dependência entre as partes, Bowersox e Cooper (1992) classificam os canais de distribuição em:

- canais de transações únicas: os negócios são realizados prevendo-se que uma nova transação não ocorrerá. Assim, o arranjo do canal só vai existir até o cumprimento dos termos especificados na transação, incluindo as garantidas do pós-venda;

- canais convencionais: os membros do canal - produtor, atacadistas e varejistas-, funcionam de maneira independente, cada um procurando maximizar o seu lucro, mesmo que isso possa reduzir o lucro do sistema como um todo;

- canais verticais de marketing: é um dos desenvolvimentos mais importantes no gerenciamento dos canais nos últimos anos. Nesse tipo de arranjo, os participantes reconhecem a sua interdependência. A administração do canal é centralizada com o objetivo de obter maior eficiência e impacto de marketing. Para que esse tipo de canal funcione é necessário que todos os participantes aceitem um papel específico no arranjo, atuem cooperativamente e que uma empresa desempenhe o papel de líder. O líder é normalmente a empresa dominante em termos de tamanho a qual cabe o papel de resolver os possíveis conflitos no canal dando estabilidade ao arranjo, bem como planejar e direcionar os caminho futuros. 
Tanto os produtores como os atacadistas e os varejistas podem ser lideres do canal. Atualmente, em função da crescente concentração que vem ocorrendo no varejo com a consolidação das grandes cadeias varejistas, o poder está saindo das mãos dos fabricantes e migrando para os varejistas (ANDERSON; DAY; RANGAN, 1997).

Segundo Churchill e Peter (2000) os canais verticais de marketing podem ser de três tipos: administrativos, empresariais e contratuais:

- Administrativos: empresas separadas desenvolvem um programa abrangente para distribuir uma linha de produtos. Há um membro que exerce poder de forma que as decisões levem em conta o canal como um todo, com procedimentos similares de contabilidade, processamento de pedidos, cooperação nas comunicações de marketing;

- Empresariais: uma única empresa possui e controla a maior parte ou todo o canal. Tipicamente uma corporação opera as instalações de produção, depósitos e lojas de varejo;

- Contratuais: foram desenvolvidos para aumentar o controle sem possuir todos os níveis da distribuição. Consistem em canais cujos membros são ligados por contratos formais especificando os direitos e responsabilidades de cada um, como é o caso dos contratos de franquias.

\subsubsection{Fatores determinantes para a estrutura do canal de distribuição}

Um projeto de canais de distribuição deve ser desenvolvido segundo a estratégia de produto/mercado adotada pela organização (STERN; EL-ANSARY; COUGHLAN, 1996; ANDERSON; DAY; RANGAN, 1997). Alguns dos fatores que determinam a estrutura do canal são: o nível de serviço ao cliente, fatores sociais, políticos e culturais, tecnologias disponíveis, e os custos de transação.

Com relação ao nível de serviço, são cinco as variáveis a serem consideradas (KOTLER, 2000):

- tamanho do lote: indica o número de unidades que o consumidor terá a sua disposição em um determinado canal;

- tempo de espera: o tempo médio que os clientes de determinado canal esperam para receber as mercadorias. Quanto maior o tempo de espera, mais inconveniente é para o 
consumidor. Estes tendem a preferir canais de entregas mais rápidas. Geralmente a espera é compensada por preços mais baixos para o consumidor. É o caso, por exemplo, das compras por catálogo e pela Internet;

- conveniência espacial: indica a facilidade com que o consumidor encontra o produto;

- variedade de produto: o nível de variedade fornecido pelo canal;

- apoio de serviço: caracteriza os serviços adicionais como entrega, crédito, instalação reparos, fornecidos pelo canal.

O nível de serviço está associado a elementos de pré-compra, de compra e de pós-compra (LAS CASAS, 2004):

- elementos de pré-compra: diz respeito à forma como os pedidos podem ser feitos (telefone, Internet etc.), prazos de entrega, políticas de serviços etc.;

- elementos de compra: diz respeito à entrega propriamente dita;

- elementos de pós-compra: diz respeito a alterações, trocas, ajustes e serviços auxiliares como restaurante etc.

Um aspecto importante sobre o serviço diz respeito à qualidade do serviço oferecido, que é definida como a diferença entre a expectativa do cliente e a qualidade experimentada ou percebida do serviço oferecido. Isto significa que a qualidade será considerada maior quando o serviço ofertado exceder às expectativas do cliente (GRONROOS, 1995). Os clientes avaliam os serviços recebidos baseados na sua própria percepção de valor, assim, as empresas precisam buscar continuamente oferecer serviços que excedam às expectativas dos clientes. Quando os consumidores vêem um serviço como sendo razoavelmente homogêneo, passam a se preocupar menos com o fornecedor e mais com o preço. Para isso, é necessário um monitoramento constante da percepção do cliente da qualidade do serviço oferecido e, a partir da identificação das causas das possíveis deficiências, tomar ações para melhorá-lo.

Segundo Bowersox e Cooper (1992), as prioridades na composição dos serviços devem ser avaliadas segundo nove dimensões: disponibilidade de produto; tempo de ciclo de produto; consistência do prazo de entrega; freqüência da entrega; flexibilidade do sistema de 
distribuição; sistema de informação de apoio; sistema de medição de falhas; apoio na entrega física e apoio pós-entrega ${ }^{1}$.

Segundo Bucklin (1972² apud KOTLER, 2000, p. 514) quanto maior o apoio de serviços, mais intermediários são incluídos na estrutura do canal, maiores são os custos com o canal e mais elevados são os preços para os clientes. Diferentes segmentos de mercado requerem níveis diferentes de serviços e, muitas vezes, os clientes estão dispostos a aceitarem níveis inferiores de serviços para terem preços mais baixos. A proliferação dos self-services e das lojas de descontos são exemplo disso.

Assim, os participantes do canal tendem a organizar suas atividades funcionais de forma a minimizar os custos totais do canal no que diz respeito aos níveis desejados de produção de serviços. Isso significa que os membros tendem a se especializar nas funções que desempenham de forma mais eficiente, delegando as demais a terceiros.

Segundo Stern, El Ansary e Coughlan (1996) essa tendência de especialização dos agentes do canal tem provocado no consumidor final um aumento de demanda por serviços. Para uma mesma qualidade e preço, o consumidor tem buscado outras facilidades como localização, possibilidade de compra de poucas unidades, diminuição do prazo de entrega, aumento da variedade de produtos.

Sobre esse aspecto, Narus e Anderson (1996) apontam que várias soluções utilizadas em canais de distribuição têm como foco a satisfação das necessidades dos clientes em termos de provisão de serviços. Uma delas é a formação de parcerias entre distribuidores e outros prestadores de serviços de forma a aumentar o nível de serviço no canal através da oferta de produtos e serviços complementares. Outra solução é utilizar esquemas que permitam atender demandas especiais dos clientes, o que envolve a melhoria dos sistemas logísticos (investimento em centros de distribuição) e uso intensivo de tecnologias da informação (compartilhamento de informações entre produtores e distribuidores e entre os distribuidores).

\footnotetext{
${ }^{1}$ Zeithaml, Parasuraman e Berry (1990 apud KOTLER, 2000) formulam um modelo onde se destacam as exigências mais importantes para a entrega de serviços de qualidade. Os autores identificam 5 gaps que são os causadores da deficiência percebida pelos clientes entre a qualidade do serviço esperada e a qualidade recebida. Os 5 gaps são: desconhecer as expectativas dos clientes, estabelecimento de padrões equivocados de qualidade de serviço, falha na execução do serviço, a promessa do serviço não se casa com o serviço entregue e lacuna entre o serviço percebido e o serviço esperado.

${ }^{2}$ BUCKLIN, L. P. Competition and evolution in the distributive trades. NJ : Prentice Hall, 1972.
} 
Fatores sociais e culturais, políticos e tecnológicos também influenciam a estrutura do canal. Segundo Stern, El-Ansary e Coughlan (1996), devido a eles, canais ineficientes do ponto de vista econômico podem sobreviver por muito tempo. Pode-se citar, entre os fatores culturais e sociais a taxa de analfabetismo, o hábito de testar os produtos, as mudanças no estilo de vida, a idade, a mobilidade social, o tamanho médio das famílias, a renda, o nível de educação.

Leis, sejam locais, estaduais ou federais, também podem influenciar na estruturação do canal. Elas regulam a relação entre produtores e distribuidores, procuram evitar que empresas façam uso de práticas que lesem os consumidores e diminuam a concorrência. Entre os aspectos comumente tratados, estão práticas como o direito de exclusividade, exclusividade territorial, acordos vinculados, direitos dos revendedores, certificação de produtos e processos, legislação ambiental, barreiras tarifárias etc.

Fatores físicos como o tamanho do mercado, a localização dos centros produtivos e a concentração da população também influenciam a estrutura do canal. Os canais de distribuição tendem a ser mais longos quando a produção está concentrada e mercados e população encontram-se dispersos.

Um outro elemento importante para a estrutura do canal é a tecnologia, que pode viabilizar ou não, certas formas de comercialização de determinados produtos, aumentar o fluxo de informação e melhorar a coordenação entre os agentes do canal. Exemplos de tecnologias são: o Electronic Data Interchange (EDI), a automação de estoques, o just-in-time, o gerenciamento do relacionamento com o cliente etc.

Um outro aspecto importante a ser considerado no projeto do canal é a especificidade dos ativos envolvidos (NEVES; ZUURBIER, CAMPOMAR, 2001).

A abordagem da Economia dos Custos de Transação (ETC) trabalha com os pressupostos da racionalidade limitada, e do oportunismo dos agentes econômicos - comportamento aético em benefício próprio, ex-ante, antes da efetivação do contrato ou ex-post, durante a vigência do contrato. 
Segundo Williamson (1996), as empresas buscam estabelecer estrutura de governança que minimizem os custos da transação. Os custos de transação são aqueles relacionados à ocorrência de uma transação, ou os custos de se governar o sistema. Eles podem ocorrer antes da transação - custos ex-ante, por exemplo, tempo de negociação, pesquisa de preço e qualidade, escrita de contrato etc. -, e depois da transação - custos ex-post, como por exemplo, disputas legais, monitoramento do uso da marca, monitoramento do desempenho, etc). Esses custos variam em função dos atributos de transação, ou seja, da especificidade dos ativos envolvidos, da frequiência da transação e das incertezas.

A especificidade dos ativos é considerada o atributo mais importante da transação. Ela se refere àqueles ativos que, quando utilizados para outro fim, sofrem perda de valor. Williamson (1996) considera seis tipos de ativos específicos: locacional; ativos fixos; ativos humanos; ativos dedicados; de marca e temporal. Segundo Anderson (1985), existe uma relação entre a especificidade dos ativos envolvidos e o grau de integração vertical do canal de distribuição. Por exemplo, esse atributo, quando considerado num contexto de racionalidade limitada e de oportunismo dos agentes, aumenta os riscos transacionais e os problemas de adaptação, ocasionando desta forma maior custo de transação. Essa situação favorece a integração vertical.

Isso, no entanto, pode implicar em altos investimentos e riscos para a empresa. Uma alternativa à integração vertical seria a terceirização de parte das funções dos canais de distribuição. Nesse sentido, a utilização de estruturas híbridas de governança, como os contratos de cooperação cliente-fornecedor e os contratos de franquias, podem trazer redução dos custos de transação (WILLIAMSON, 1996). Segundo Neves, Zuurbier e Campomar a análise dos ativos específica e de seus impactos ajudaria as empresas a construir esses contratos $^{3}$.

Os canais de distribuição são sistemas abertos que influenciam e são influenciados pelo meio ambiente externo. Por isso, eles tendem a mudar continuamente ao longo do tempo para se adequarem às alterações do ambiente. Modificações no canal se tornam necessárias quando: padrões de compra dos consumidores mudam, o mercado se altera, surgem novos concorrentes, surgem novas tecnologias, o produto chega aos últimos estágios de seu ciclo de

\footnotetext{
${ }^{3}$ Neves (1999) propõe que na análise sejam considerados o nível de especificidade de cada um dos ativos envolvidos e os custos de realocação dos mesmos.
} 
vida, ocorrem alterações na própria distribuição, na legislação e na economia, como distribuição de renda, disponibilidade de crédito, financiamento, etc. (KOTLER, 2000; DIAS, 1993; ALCÂNTARA, 1997; NARUS; ANDERSON, 1996; KUMAR, 1996).

Uma alteração de mercado pode se caracterizar por uma demanda crescente, o que pode levar a empresa a passar de uma distribuição seletiva para uma intensiva. A presença de novos concorrentes pode levar a empresa a retirar ou acrescentar membros específicos no canal ou até a buscar formas novas de vender seus produtos e serviços. Diferentes estágios do ciclo de vida do produto requerem diferentes canais de distribuição: os primeiros compradores tendem a pagar por canais de alto valor agregado, mas os compradores posteriores tendem a se transferir para canais de menor custo.

O surgimento de novas tecnologias pode levar a uma reestruturação do canal. É o caso das novas tecnologias da informação que têm sido apontadas como um dos principais fatores que influenciarão a organização dos canais de distribuição de vários setores da economia. Por exemplo, a disseminação do comércio eletrônico permite aos produtores vender diretamente para os consumidores finais, eliminando certos intermediários ou aumentando o seu poder de barganha sobre os canais tradicionais (MARUCA, 1999; PORTER, 2001). Ele também transfere poder de barganha para os consumidores finais, dando mais informação sobre os produtos, permitindo comparações, dando oportunidade de manifestarem sua opinião e reduzindo o custo da mudança (ALBERTIN 2000; PORTER, 2001).

De outro lado, as novas tecnologias da informação têm permitido uma melhoria nos fluxos de informação entre os diversos agentes do canal, o que, segundo apontam Silva e Alcântara (2001) e Narus e Anderson (1996), tem tornado factíveis formas mais cooperativas de relacionamento entre os membros do canal de distribuição.

Ressalta-se neste ponto que as decisões sobre canais de distribuição são, por natureza, de longo prazo e as mudanças são freqüentemente difíceis (STERN; EL-ANSARY; COUGHLAN, 1996). Conforme aponta Neves (1999), grandes investimentos são feitos pelos participantes e existem barreiras à saída, dada a dificuldade de realocação destes investimentos. A troca de canais envolve custos elevados ligados à procura de novos canais, à especificidade da força de vendas, à perda de vendas, estoques, treinamento etc. 


\subsubsection{Estratégias de distribuição}

Com relação à estratégia das empresas junto aos canais de distribuição, Stern, El-Ansary e Coughlan (1996) e Rosembloon (1999) as classificam em push e pull. A estratégia push consiste em forçar os produtos através do canal tendo por base as capacidades produtivas do produtor. Na estratégia pull visa-se fortalecer a importância do consumidor como puxador de vendas; o produtor se adapta às mudanças de mercado com base nos dados dos pontos de vendas e no movimento dos produtos.

Quanto à cobertura de mercado, são três as possíveis estratégias de distribuição: distribuição exclusiva, distribuição seletiva e distribuição intensiva.

A distribuição exclusiva ocorre quando o fabricante vende produtos por meio de um único atacadista ou varejista numa determinada área. O intermediário recebe o direito exclusivo de vender o produto no território. É usada quando um produto requer um trabalho de venda especializado, investimento em instalações ou estoques específicos e o produtor deseja manter controle sobre o nível de serviço e a produção de serviço oferecidos. Geralmente envolve acordos de exclusividade, nos quais os revendedores concordam em não vender marcas concorrentes. Produtos que tradicionalmente são distribuídos de forma exclusiva são carros novos e algumas marcas de vestuário.

A distribuição seletiva envolve a utilização de determinados intermediários que queiram comercializar um produto específico. Nesse caso, os intermediários têm que cumprir determinadas exigências dos produtores. Critérios importantes a serem considerados pelos produtores são localização, reputação e clientela. A vantagem é que o produtor não precisa dispersar esforços em muitos pontos de vendas e pode conseguir uma boa cobertura de mercado. Os produtos que mais se adequam a este sistema são vestuários, móveis, grandes eletrodomésticos e carros usados ${ }^{4}$.

$\mathrm{Na}$ distribuição intensiva os produtores vendem seus produtos e serviços por meio do maior número de pontos-de-venda possível. O mais importante é o volume de vendas. Aspectos como aparência de loja ou os serviços oferecidos são relegados a segundo plano. As

\footnotetext{
${ }^{4}$ São os bens chamados de compra comparada, ou seja, aqueles que o consumidor, no processo de seleção e compra, compara características como adequação, qualidade, preço e estilo (KOTLER, 1996).
} 
vantagens desse tipo de distribuição são a pulverização dos riscos e a maior cobertura de mercado. É indicada para produtos de conveniência e com alto índice de reposição.

Essas estratégias não são excludentes. Um produtor pode adotar tipos de canais diferentes simultaneamente. É a estratégia chamada de multicanais. Em alguns casos as empresas usam múltiplos canais para adequar-se a uma estratégia de várias marcas (CHURCHILL; PETER, 2000). A introdução de mais canais pode trazer alguns importantes benefícios para as empresas (KOTLER, 2000):

- maior cobertura de mercado: um novo canal pode atingir um segmento de mercado que não era atingido pelos canais atuais;

- redução do custo: o acréscimo de um novo canal pode reduzir os custos de vendas para um grupo de clientes existente;

- venda mais personalizada: um novo canal pode ter características de venda que se adaptem melhor às necessidades do cliente, por exemplo, o acréscimo de uma força de vendas técnica para vender equipamentos complexos.

Todavia é preciso ressaltar que o acréscimo de novos canais pode trazer problemas de conflito e controle, pois dois ou mais canais podem acabar concorrendo pelos menos clientes. Além disso, os novos canais podem ser mais independentes e tornar a cooperação mais difícil.

A estratégia de multicanais também é utilizada pelas empresas em ambiente de aumento de concorrência e de incertezas: nessas condições, as empresas experimentam vários canais para escolher os mais eficientes (ANDERSON; DAY; RANGAN, 1997; WISE; BAUMGARTNER, 1999).

\subsubsection{Gerenciando o relacionamento no canal}

Uma vez que o canal foi estabelecido, é necessário haver coordenação e cooperação entre seus membros para que eles alcancem seus objetivos e criem valor para os clientes (STERN; ELANSARY; COUGHLAN, 1996). Contudo, diferenças de objetivos dos membros do canal quanto às margens de lucro e ao desempenho das funções de distribuição podem gerar conflitos (CHURCHILL; PETER, 2000; KOTLER, 2000). Por exemplo, os conflitos podem surgir devido a grande dependência dos intermediários em relação ao fabricante. Isso é patente no caso da distribuição exclusiva, onde o destino dos revendedores, como é o caso das 
concessionárias de automóveis, é afetado pelas decisões sobre o produto e preços do fabricante.

Os conflitos são basicamente de dois tipos: vertical e horizontal. O vertical ocorre entre membros do canal em diferentes níveis - produtor com atacadista, atacadista com varejista. Freqüentemente ocorre quando um produtor pode decidir vender diretamente para o consumidor, ou quando um membro do canal acha que o outro não está fazendo o trabalho direito, ou ainda quando o produtor tenta impor políticas de serviços e preços aos seus distribuidores, como ocorreu com a GM nos Estados Unidos. No conflito horizontal ocorrem divergências entre membros do mesmo nível do canal: varejistas com varejistas, atacadistas com atacadistas. Normalmente os conflitos horizontais são gerados por discordâncias quanto aos limites de território e de exclusividade, aos preços e às práticas competitivas (CHURCHILL; PETER, 2000; KOTLER, 2000).

A redução do conflito pode se dar através da liderança: um membro é reconhecido pelos outros como detentor do poder para tomar decisões (CHURCHILL; PETER, 2000; KOTLER, 2000). A capacidade dos líderes de gerenciar conflitos confere a eles vários tipos de poder para conseguir cooperação. Pode-se aplicar prêmios e sanções aos membros do canal. Dentre os prêmios estão a adoção de margens de lucro mais altas, condições especiais, prêmios, verbas para propaganda cooperativa. As sanções vão desde ameaças de redução de margens e aumento do tempo de entrega ao encerramento do relacionamento. Outras formas de poder são as exigências contratuais, a detenção de um conhecimento específico ou informações importantes e ainda a reputação dos membros do canal.

Segundo Kumar (1996), o uso do poder, que no passado recente foi vantajoso para se obter cooperação dos membros do canal não tem mais garantido às empresas vantagem competitiva de longo prazo. De acordo com Narus e Anderson (1996), as empresas mais competitivas serão aquelas que explorarão formas mais cooperativas de relacionamento no canal. Bowersox e Cooper (1992) apontam que a adoção de posturas mais cooperativas e de enfrentamento rápido de conflitos são essenciais para que os objetivos de estimular e satisfazer a demanda sejam atingidos.

Os aspectos fundamentais para a construção de relacionamentos mais cooperativos dizem respeito à existência de comprometimento e de confiança entre os membros do canal. Várias 
pesquisas têm mostrado que a existência de comprometimento e confiança melhora a coordenação, reduz o conflito e aumenta a satisfação dos membros do canal (ANDERSON; WEITZ, 1992; DONEY; CANNON, 1997; MORGAN; HUNT 1994).

Um dos aspectos mais importantes para se obter comprometimento e confiança entre os membros do canal diz respeito ao nível de comunicação. De acordo com KUMAR (1996) e ANDERSON e WEITZ (1994), a comunicação bilateral melhora a coordenação e reduz o conflito no canal. São diversas as práticas que podem ser utilizadas para essa finalidade, entre as citadas por aqueles autores estão a realização periódica de reuniões com os membros do canal para discutir seus problemas, o estabelecimento de comitês de aconselhamento para que os distribuidores possam tratar de seus assuntos particulares com o produtor, as reuniões com os distribuidores onde as decisões e políticas da empresa possam ser explicadas.

Um outro fator importante citado por Kumar (1996) é a imparcialidade. O membro de maior poder no canal deve assegurar que todas as partes terão oportunidades iguais. Por exemplo, evitar mudanças bruscas de volume de negócios, manter o mesmo preço para todos etc. Um outro ponto citado por Kumar (1996) é a limitação do número de parceiros, selecionados entre os que têm valores similares, poder reduzir o potencial de conflitos e ao mesmo tempo manter o compromisso de exclusividade territorial dos distribuidores.

De acordo com Anderson e Weitz (1994), o nível de comprometimento dos membros do canal também está relacionado à existência de investimentos específicos dos produtores nas redes de distribuição, tais como fornecimento de facilidade para a comercialização de uma linha específica de produto, a realização de promoções que ajudam a fixar a marca e o distribuidor na mente do consumidor e treinamentos.

Segundo Alcântara e Silva (2001), o uso de tecnologias da informação, como a EDI, que propicia a formação de redes entre áreas operacionais das diferentes empresas facilitando o aprendizado e a troca de conhecimento, é outra iniciativa importante para o estabelecimento de relacionamentos mais cooperativos.

Rosembloon (1999) apresenta várias técnicas que tendem a fortalecer o relacionamento entre produtores e distribuidores: 
- procurar premiar com margens maiores os membros do canal e efetuam maior quantidade de tarefas de distribuição;

- prover forte suporte de propaganda e promoção para os membros do canal;

- desenvolver um balanceamento ideal entre estratégias push e pull;

- desenvolver cotas de vendas para os membros do canal com base em análise de seu potencial de mercado;

- prover exclusividade territorial;

- oferecer assistência financeira;

- oferecer suporte aos membros do canal em gestão;

- prover os membros do canal de pesquisas de marketing sobre seus mercados alvos;

- estabelecer conselho de distribuidores para prover informações para a tomada de decisão sobre o canal e seus membros.

\subsubsection{O varejo}

"O varejo inclui todas as atividades relativas à venda de produtos ou serviços diretamente aos consumidores finais, para uso pessoal e não-comercial" (KOTLER, 2000, p. 540). Qualquer organização que venda para o consumidor final, seja ela um fabricante, atacadista ou varejista, está fazendo varejo. A maneira como os produtos são vendidos (pessoalmente, por catálogo, ou pela Internet) ou onde eles são vendidos (na loja ou na casa do consumidor) não é importante.

Os varejistas podem criar valor para fabricantes e atacadistas e para os consumidores finais. Para os fabricantes e atacadistas, colocando os produtos à disposição dos consumidores, coletando e divulgando dados sobre os consumidores e seu comportamento de compra, assumindo riscos na compra de produtos perecíveis, promovendo os produtos dos fabricantes, oferecendo serviços eficientes de distribuição física. Para os consumidores finais, colocando produtos à disposição no momento e no lugar em que os consumidores desejam comprá-los, facilitando as compras ao aceitar cartões de crédito ou oferecer planos de pagamento e venda de produtos em pequenas quantidades, tornando conveniente ou prazerosa a experiência de comprar, oferecendo variedade de marca para que os consumidores possam fazer comparações e fornecendo serviços pré e pós-venda (CHURCHILL; PETER, 2000). 
Elo mais próximo do consumidor final, os varejistas têm conhecimento em tempo real do comportamento dos consumidores. Isso, aliado à crescente sofisticação de marketing e ao uso de tecnologias da informação e a uma crescente concentração do varejo têm alterado a importância estratégica dos distribuidores em relação aos fabricantes, gerando um novo equilíbrio de poder entre eles. Em muitos setores, de bens de consumo, por exemplo, devido a esses fatores, o poder está migrando das mãos dos produtores para os varejistas.

\subsubsection{Os tipos de varejistas}

Em geral, as vendas no varejo ocorrem em lojas, ou por meio do que se convencionou chamar varejo sem loja que engloba desde os sites da Internet até as vendas por catálogo (digital ou em papel), telefone/ fax.

O varejo com loja é útil quando os consumidores desejam ver e manusear os produtos, quando uma loja é o local tradicional para a compra de determinados produtos, quando são comuns as compras adicionais por impulso e quando os consumidores desejam usar os produtos imediatamente. Entre os principais tipos de varejo com lojas estão as lojas de departamentos, as lojas de conveniência, as lojas especializadas, os supermercados.

O varejo sem loja é o formato de varejo no qual o contato com o consumidor ocorre fora de uma loja. É útil quando os consumidores estão dispostos a esperar pela encomenda e podem tomar a decisão de comprar sem ver ou manusear os produtos. Esta estratégia cria valor para os consumidores através da conveniência e dos preços baixos, além de permitirem que os consumidores comprem produtos inexistentes em suas cidades. É uma boa opção quando a demanda pelos produtos é pequena em determinado local não justificando a instalação de uma loja e/ou os varejistas locais não querem negociar os produtos devido à baixa demanda (KOTLER, 2000; CHURCHILL; PETER, 2000)

O varejo sem loja pode ser dividido em: venda direta, que engloba a explicação pessoal e demonstração de um produto feita por um representante de venda; o marketing direto, que engloba as vendas por catálogo, telemarketing e comércio-eletrônico; as máquinas de vendas, que liberam produtos quando se insere moedas, fichas ou cartão de crédito. 
Um formato de varejo surge, desfruta de um período de crescimento acelerado, atinge a maturidade e então declina. Esse processo que passa por estágios de crescimento e declínio é descrito na literatura como o "Ciclo de Vida do Varejo" (DAVIDSON; BATES; BASS, 1976). Novos formados de varejo surgem então para atender às diversas preferências dos clientes quanto ao nível de serviço e ao serviço específico.

A base do varejo é a prestação de serviços. A definição do mix de serviço oferecido é fator central para a competitividade (KOTLER, 2000). Os níveis de serviço oferecido pelos varejistas vão do auto-serviço, onde são os clientes que procuram, compram e selecio nam os produtos, ao serviço completo, onde vendedores estão prontos para dar suporte em todas as fases de procurar, comprar e selecionar (KOTLER, 2000). De fundamental importância para o varejo é a qualidade dos serviços prestados, como já apresentado neste capítulo (ver item 2.1.2), pois os consumidores não vão somente atrás de um produto, mas de atendimento também.

\subsubsection{Decisões de marketing}

São variáveis as chaves para o posicionamento estratégico do varejista, o mercado alvo, o ambiente da loja, o preço, a promoção, a localização, os serviços e o sortimento.

- Mercado-alvo: de sua definição dependem as decisões sobre sortimento de produtos, preço, ambiente da loja, promoção e serviços;

- Sortimento: decidir sobre a amplitude (limitado ou amplo) e a profundidade (superficial ou profundo) do sortimento dos produtos;

- Serviços: decidir quais serviços serão oferecidos no pré-compra, na compra e no póscompra e os serviços auxiliares, entre os quais estão balcões de informação, troca de cheques, estacionamento, restaurante, consertos, crédito, fraldário. O mix de serviços é um dos aspectos-chave para diferenciar uma loja da outra;

- Imagem e atmosfera da loja: imagem envolve tudo o que os consumidores pensam sobre uma determinada loja ou rede do varejo. Contam as "características físicas da loja, suas mercadorias, preços, propaganda e vendedores e incluem também estados emocionais. Com relação à atmosfera, observam-se fatores como arquitetura, iluminação e layout que chamam a atenção do cliente e estimulam as vendas. Músicas e aromas, também fazem 
parte da atmosfera. Para o varejo sem loja, a imagem envolve a qualidade do catálogo, pessoal bem treinado para ser representante e design do site.

- Preços: são definidos em relação ao mercado-alvo, ao mix de sortimento, de produtos e serviços e à concorrência. Deve-se decidir também sobre a política de posicionamento de preços altos, médios ou baixos, bem como sobre a liderança em preços.

- Promoções: são utilizadas para gerar tráfego e compras. Entre as principais ferramentas de promoção estão as liquidações, cupons de descontos, programas de recompensa, amostras grátis etc.;

- Localização: as decisões são tomadas considerando quantos consumidores potenciais estarão nas proximidades, a presença de concorrentes, o tipo de ponto, acessibilidade, vantagens da localização em um centro, condições de ocupação e considerações legais.

\subsubsection{Tendências no varejo}

Alguns pontos devem ser destacados com relação ao varejo. Em primeiro lugar, aspectos como localização, sortimento, e serviços não têm mais garantido vantagens competitivas. Em busca de volumes, fabricantes de grandes marcas têm colocado seus produtos em todos os lugares. O resultado disso é que os artigos vendidos nas lojas de varejo tornaram-se cada vez mais parecidos. A diferenciação nos serviços também tem diminuído, pois eles logo são copiados e os clientes não estão dispostos a pagar mais por produtos idênticos com poucas diferenças nos serviços oferecidos. Algumas das tendências que estão sendo observadas no varejo segundo em Kotler, (2000), Churchill e Peter (2000) e Wise e Baumgartner (1999) são:

- novos formatos e combinações de varejo têm surgido continuamente. No entanto, esses novos formatos têm se mantido por menos tempo no mercado, são rapidamente copiados e perdem seu caráter de novidade;

- há um aumento expressivo do varejo sem loja em função dos avanços das novas tecnologias da informação;

- a concorrência está se dando entre intraformatos, ou entre diferentes formatos de lojas;

- os varejistas estão se tornando vendedores de mercadorias de massa ou varejistas especializados. Estão surgindo varejistas com enorme poder, muitos dos quais estão forçando os produtores a entregarem produtos para serem comercializados com a marca do produtor; 
- o surgimento das organizações de varejo: são lojas que fazem parte de alguma forma corporativa de varejo. Entre os principais tipos estão as redes corporativas, as redes voluntárias, as cooperativas de varejo, as cooperativas dos consumidores e as franquias. Os principais objetivos desse formato de varejo é conseguir economias de escala, maior poder de compra e maior reconhecimento de marca.

- os consumidores estão preferindo a conveniência de comprar tudo em um único lugar, como os shoppings centers;

- a tecnologia está se tornando uma ferramenta competitiva fundamental. Estão sendo usadas para oferecer aos clientes melhor atendimento e aumentar a produtividade dos funcionários. Um exemplo é a transação pela Internet, que amplia o horário de atendimento e reduz os aborrecimentos comuns num processo de compra. Os varejistas utilizam computadores para gerar previsões melhores, controlar custos, fazer pedidos por via eletrônica.

- tem-se verificado um notável aumento dos estabelecimentos que oferecem um local para as pessoas se encontrarem como cafeterias, bares etc.

- quanto aos serviços propriamente ditos, os clientes estão ficando mais experientes na compra de serviços de suporte e assistência técnica ao produto e estão pressionando pela separação do pacote de serviços. Os consumidores querem preços separados para cada elemento de serviço, além do direito de escolher os elementos que querem.

\subsection{A distribuição de carros novos}

Grosso modo, a distribuição de carros novos ocorre da seguinte forma: as montadoras vendem seus veículos para uma rede de inúmeras franquias independentes, que são as responsáveis por disponibilizar os carros para o consumidor final. Essas franquias, ou revendas ${ }^{5}$ trabalham preferencialmente com uma única marca de veículos ou representam uma única montadora. As montadoras estruturam suas redes de distribuição de forma que elas desempenhem cinco funções principais: venda de carros novos, venda de carros usados, manutenção de veículos, distribuição de peças de reposição e financiamento de veículos (MERCER, 1994; CHANARON; JULLIEN, 1999). Trata-se de um canal indireto, composto pelo produtor, a montadora, e pelo varejista, a revenda.

\footnotetext{
${ }^{5} \mathrm{O}$ termo revenda será usado neste texto para designar de forma genérica uma franquia ou uma concessionária.
} 
Esse sistema de distribuição baseado em franquias nasceu nos Estados Unidos na década de 30, consolidando-se nos anos 50 (MERCER, 1994). Segundo Mercer (1994), os motivos que podem ter contribuído para o surgimento e a consolidação dessa estrutura de distribuição foram:

- não existiam canais diretos de distribuição economicamente viáveis. Assim, a distribuição via rede de franquias tornourse uma alternativa a integração vertical economicamente atraente, pois evitaria os investimentos necessários por parte das montadoras para que a comercialização fosse feita através de lojas próprias, além de dividirem os riscos ${ }^{6}$;

- os consumidores, inexperientes, necessitavam de uma quantidade significante de informação; informação esta que seria melhor dada por um distribuidor local;

- havia a necessidade de muitos pontos de serviços devido principalmente às freqüentes necessidades de manutenção dos veículos - a confiabilidade dos veículos era menor;

- havia uma expectativa de vendas crescentes que levaram as montadoras a exigir exclusividade das franquias na comercialização das marcas;

- a integração de funções - venda de carros novos, venda de carros usados, reposição de peças, serviços e financiamento - no nível de cada franquia justificava-se, pois o volume de negócio era suficiente (necessidade de reparos constantes), e os custos fixos eram relativamente baixos (as ferramentas necessárias não eram muito sofisticadas).

Existem inúmeras variações em torno do sistema de distribuição de veículos, porém algumas características são comuns à maioria dos países europeus, Estados Unidos e Brasil:

- o sistema procura atender o consumidor final independente da localização geográfica, oferecendo um conjunto integrado de funções (venda de carros novos, venda de carros usados, serviços de manutenção, distribuição de peças de reposição e financiamento para compra de veículos);

- o sistema se baseia no princípio da exclusividade: cada fabricante possui sua própria rede de distribuição, desenvolvida para ser ponto exclusivo de venda do fabricante ou marca. $\mathrm{O}$ que se busca com isso é estabelecer a identidade da marca;

\footnotetext{
${ }^{6}$ Um dos principais propósitos de emprego do sistema de franquia é, segundo a Teoria da Agência, minimizar os custos de gerenciamento e controle da comercialização, visto que estes custos seriam repassados ao franqueado. Além disso, outra importante vantagem no emprego do sistema de franquia refere -se ao fato de que, a partir do contrato de divisão dos riscos, o franqueado possuiria um maior incentivo - quando comparado à atuação de um gerente de loja própria - em desempenhar suas atividades da melhor forma possível, contribuindo assim para o sucesso não apenas de sua unidade, mas de toda a rede. Ver Lafontaine (1992) e Sappington (1991).
} 
- a distribuição está baseada no sistema push (empurrar veículos para o mercado), com exceção do Japão e da Alemanha, onde uma porcentagem significativa dos veículos é produzida a partir do pedido do consumidor (build-to-order) (MERCER, 1997; BUZZAVO; VOLPATO, 2001).

Em cada país, leis específicas procuram balancear as relações entre montadoras e revendedores. De modo geral, as relações entre montadoras e revendas são conflituosas com contratos desvantajosos para os distribuidores. Um dos aspectos centrais é a questão da exclusividade de marcas. Ou seja, como revendedores exclusivos, o destino das franquias de automóveis é afetado pelas decisões sobre o produto e o preço dos fabricantes. O aspecto regulatório é hoje um dos fatores relevantes para a distribuição (NISHIMURA; MORITA, 2002; KNUPFER; RICHMOND; ARK, 2003) e suas implicações serão discutidas mais adiante neste capítulo.

Desde meados da década de 1990, o modelo de distribuição baseado em redes de franquias exclusivas de cada marca, que integra num mesmo local várias funções, vem sendo questionado na Europa e nos Estados Unidos. Mudanças no mercado, no comportamento do consumidor, no desenvolvimento e difusão de novas tecnologias da informação e alterações na regulamentação que dispõe sobre a distribuição de veículos novos, estão entre os fatores que pressionam as mudanças no setor.

A seguir serão analisados os principais elementos da distribuição de carros novos nos Estados Unidos, Europa e no Japão, a crise no sistema de distribuição e as inovações em curso no varejo de carros novos nesses mercados. Em seguida será focalizada a situação brasileira.

\subsection{1 - A distribuição de veículos nos Estados Unidos, na Europa e no Japão e no Brasil}

\subsubsection{1 - A distribuição de veículos nos Estados Unidos}

Nos Estados Unidos cada montadora possui a sua rede de distribuição composta por franquias independentes que distribuem veículos de uma única marca. As redes de distribuição são bastante heterogêneas: em suas composições aparecem desde pequenos revendedores até grandes franquias com várias lojas como a AutoNation (KNUPFER; RICHMOND; ARK, 
2003). Estima-se que, em 2002, estavam em atividade 21.725 franquias $^{7}$ nos EUA, que comercializaram cerca de 16,8 milhões de carros novos nos Estados Unidos (NADA, 2003).

Uma franquia tradicional possui as 5 funções integradas: venda de carros novos, venda de usados, distribuição de peças de reposição, serviços de manutenção e financiamento (MERCER, 1997). Os revendedores trabalham com estoques de carros e $70 \%$ das vendas são realizadas com itens disponíveis nesses estoques (stock push) (BUZZAVO; VOLPATO, 2001).

Nos últimos 20 anos, o setor vem passando por um processo de redução do número de revendas e de concentração de capital através da aquisição de pequenas e médias revendas por grandes revendedores no sentido de obter maior escala de vendas e redução de custos. Em 1983 o número de franquias era de 24.725 e em 2002 diminuiu para 21.725. Em 1983 existiam 8.600 revendas com vendas anuais inferiores a 150 carros novos, enquanto em 2003 são apenas 2.390 franquias nessa situação. Contrastando com essa situação, em 1983, 3.500 revendedores comercializavam mais de 750 carros novos por ano, contra 6.952 na atualidade (NADA, 2003).

Buzzavo e Volpato (2001) estimam que cerca de 30\% das franquias americanas pertencem a grandes revendedores, sendo que, $5 \%$ desses grandes grupos são responsáveis por $30 \%$ das vendas totais de veículos.

Segundo dados da NADA (2003), em 2002, a distribuição de peças e os serviços de manutenção juntos foram responsáveis por cerca de $48 \%$ do lucro operacional total nas revendas americanas. A venda de carros novos com $35 \%$ e a venda de carros usados com $17 \%$ (Tabela 2.1).

\footnotetext{
${ }^{7}$ Considerando as Big Three, Ford e DaimlerChrysler têm aproximadamente 4.000 revendas cada, e a GM mais de 7.500 (KNUPFER;RICHMOND; ARK, 2003).
} 
Tabela 2.1 - Origem dos ganhos da revenda nos Estados Unidos em 2002.

\begin{tabular}{lcc}
\hline Funções & $\begin{array}{c}\text { \% sobre as } \\
\text { vendas totais }\end{array}$ & $\begin{array}{c}\text { \% sobre o lucro operacional } \\
\text { total }\end{array}$ \\
\hline Venda de carros novos & 59,6 & 35 \\
Venda de carros usados & 28,6 & 17 \\
Dist. de peças e serviços & 11,8 & 48 \\
\hline
\end{tabular}

Fonte: NADA (2003)

No início dos anos 2000, alguns sites de vendas de carro apareceram nos Estados Unidos. No entanto, as empresas pontocom que tentaram se estabelecer começaram a enfrentar alguns problemas. Em primeiro lugar, sofreram a pressão dos concessionários tradicionais, que também entraram no negócio da Internet. Em segundo lugar, os revendedores tradicionais utilizaram sua influência nas leis para limitar a atuação desses novos intermediários. Em terceiro lugar, eles enfrentaram problemas de estoques e não conseguiram atender à demanda dos consumidores (BRADSHER, 2000).

O formato de negócio na Internet que, a princípio, acabou prevalecendo nos Estados Unidos, não foi o site de comércio eletrônico puro, mas o de serviço de informação para quem compra um carro. O Autobytel e o Car Point são exemplos desses novos intermediários. Esses sites têm uma rede de revendedores associados dos quais eles cobram uma taxa e uma comissão. Eles fornecem informações sobre os carros, preço, etc. e agem como intermediadores para os interessados em vender e comprar, aproximando os potenciais compradores dos revendedores (NISHIMURA; MORITA, 2002).

Há muita controvérsia sobre a atuação dos sites de comércio-eletrônico de carros. O impacto sobre o canal de vendas é questão em aberto. Tem-se que, segundo Nishimura e Morita (2002), os consumidores com acesso às informações dos sites assumem uma postura mais agressiva no processo de compra. Segundo pesquisa da Borrel Associates Inc. de outubro de $2003^{8}$, nos Estados Unidos, cerca de $60 \%$ dos consumidores que procuram informações sobre carros utilizam sites automotivos, sejam eles independentes, dos revendedores ou das próprias montadoras.

\footnotetext{
${ }^{8}$ LOCAL and National Automotive Advertising Online. Borrel Associates Inc. Disponível em: www.borrellassociates.com/research.html . Acesso em: 6 nov. 2003.
} 
Nos Estados Unidos, a relação entre montadoras e revendedores é regulada por leis federais e leis estaduais, sendo estas últimas as mais importantes (HOFFMEISTER, 1995). Os principais pontos a serem destacados são (HOFFMEISTER, 1995):

- a relação entre montadoras e distribuidores é regulada através de contratos de franquias;

- as leis estabelecem que as revendas são as únicas a ter o direito de vender carros novos e estão livres para colocar os preços que acreditem estar mais de acordo com o mercado local;

- as leis garantem exclusividade territorial aos revendedores já estabelecidos. Caso as montadoras optem por uma franquia adicional, elas devem modificar todas as franquias já estabelecidas na área e estas terão um prazo para contestar na justiça;

- as leis protegem os distribuidores em relação ao rompimento injustificado por parte das montadoras;

- as leis impedem as montadoras de vender diretamente ao consumidor final;

- as leis impedem as montadoras de possuir ou operar revendas;

- as leis negam às montadoras o direito de aplicar cláusulas de exclusividade nos contratos de franquias (Embora a lei não permita cláusulas de exclusividade, ela pode ser imposta de outra forma pelas montadoras, como por exemplo através de incentivos financeiros às revendas que trabalham com uma única marca. Um dos motivos alegados pelas montadoras para incentivarem a exclusividade de marcas é a manutenção da qualidade do serviço associado à marca);

- é permitido às montadoras selecionar seus revendedores, determinar o número e a localização das revendas, determinar a qualificação e os padrões da franquia (por exemplo, localização e tamanho do showroom);

- mudanças de proprietários devem ter o consentimento da montadora.

A regulamentação nos Estados Unidos foi estabelecida para favorecer o setor de distribuição em detrimento das montadoras. É uma restrição ao aumento de controle das montadoras sobre a rede e, atualmente, é um dos entraves às mudanças no setor (KNUPFER; RICHMOND; ARK, 2003; NISHIMURA; MORITA, 2002). Mudanças estruturais encontram restrições nas leis, que dificultam a ação das montadoras sobre as redes para melhorias no sistema. 


\subsubsection{A distribuição de veículos na Europa}

Em vários países europeus, como Reino Unido, Alemanha, França e Itália, a estrutura de revenda era composta de revendedor principal, sub-revendedores e agentes, ligados contratualmente aos revendedores principais. Os sub-revendedores eram, na maioria das vezes, pequenas oficinas de manutenção que vendiam carros novos fornecidos pelo revendedor principal (WOMACK; JONES; ROOS, 1992; CHANARON; JULLIEN, 1999). Desde 1990, o setor vem passando por um processo de concentração: os sub-revendedores estão desaparecendo e o número de revendedores principais está sendo reduzido. Segundo dados do European Car Distribution Handbook (apud BUZZAVO; VOLPATO, 2001, p.12) considerando os 16 mercados europeus, o número de franquias passou de 60.000, em 1997, para 55.000, em 2000. O formato de varejo que está se configurando é de um revendedor principal com várias lojas espalhadas (CHANARON; JULLIEN, 1999). É preciso ressaltar, no entanto, que a magnitude com que o fenômeno ocorre varia muito entre os países europeus. Segundo Buzzavo e Volpato (2001), há ainda na Europa um grande potencial para a redução do número de revendedores. Segundo os autores, em muitos casos, as montadoras pretendem estabelecer um relacionamento mais forte com poucos intermediários, que representariam diferentes marcas de uma mesma montadora numa determinada área geográfica.

Existem aproximadamente 55.000 revendas na Europa, pertencentes a cerca de 45.000 proprietários. Oitenta e um porcento são franquias exclusivas de uma montadora e $66 \%$ exclusivas de uma única marca. Sessenta e um porcento das revendas comercializam menos que 150 carros novos por ano, enquanto apenas 3\% comercializam mais de 1.000 carros por ano (BUZZAVO; VOLPATO, 2001). Em 2000, elas comercializaram cerca de 16,9 milhões de veículos (BUZZAVO; VOLPATO, 2001). Nota-se que para um mercado praticamente do mesmo tamanho, a Europa possui mais que o dobro de revendas que os Estados Unidos, e há também diferenças significativas quanto à concentração e à estrutura da distribuição de país para país.

Na Alemanha a distribuição é muito fragmentada: existem mais de 15.000 revendas que comercializam um baixo volume de veículos por ano. Atualmente o setor vem passando por um processo de concentração. Dois aspectos da distribuição chamam a atenção na Alemanha:

\footnotetext{
${ }^{9}$ EUROPEAN car distribution handbook, HWBI Ltd.
} 
1) algumas montadoras (especialmente a Mercedes-Benz e a Volkswagen) operam um grande número de lojas próprias; e 2) uma parcela significativa da produção é realizada sob encomenda (build-to-order) e os consumidores estão habituados a esperarem pelo veículo que desejam (sistema pull) (BUZZAVO; VOLPATO, 2001).

No Reino Unido o varejo de carros novos é altamente concentrado: 20 grandes revendedores possuem $12 \%$ das revendas e $60 \%$ dos carros são vendidos por revendedores que possuem duas ou mais lojas (BUZZAVO; VOLPATO, 2001). As revendas são menos dependentes da venda de carros novos, sendo que as principais fontes de lucro são a venda de carros usados, financiamento e manutenção (Tabela 2.2).

As revendas trabalham com pouco estoque. Cada montadora opera alguns poucos centros de distribuição, onde os carros são estocados e disponibilizados aos revendedores. Assim, as revendas podem atender melhor os consumidores quanto à especificação do veículo desejado. Caso a especificação não esteja disponível, é feito um pedido para a montadora (BUZZAVO; VOLPATO, 2001).

Itália e França têm estruturas de distribuição similares: um revendedor principal que opera um grande número de sub-revendedores e agentes. Na Franca, a Renault opera grande número de revendas; já na Itália esse fenômeno é bem limitado. Quanto ao lucro, as revendas dependem principalmente da venda de carros novos (BUZZAVO; VOLPATO, 2001). A tabela 2.2 abaixo apresenta a origem das margens de lucro das revendas na França, Alemanha e Reino Unido.

Tabela 2.2 - Origens das margens de lucros das revendas em países europeus em 1994.

\begin{tabular}{lccc}
\hline Funções & França & Alemanha & $\begin{array}{c}\text { Reino } \\
\text { Unido }\end{array}$ \\
\hline Dist. partes e serviços & $52 \%$ & $60 \%$ & $62 \%$ \\
Veículos novos & $38 \%$ & $35 \%$ & $19 \%$ \\
Veículos usados & $10 \%$ & $5 \%$ & $19 \%$ \\
\hline Fonte: ICDP apud & &
\end{tabular}

Fonte: ICDP apud Chanaron e Ju llien (1999, p. 345)

Até 2002 a distribuição de veículos na Europa foi regida pelas leis 123/85 e 1475/95. As relações entre montadoras e revendedores eram reguladas por contratos de franquias e a venda 
de carros novos era orientada pelas regras de exclusividade (as montadoras concedem aos revendedores uma área exclusiva de venda) e de seletividade (as montadoras estabelecem padrões para os revendedores como, tamanho do showroom, tipos de serviços a serem oferecidos, treinamento dos vendedores, metas de vendas etc.) (BUZZAVO; VOLPATO, 2001), caracterizando a Distribuição Seletiva-Exclusiva. Essas regras impediam os revendedores de venderem outras marcas e de repassarem seus carros para sub-revendedores não autorizados pelas montadoras. As revendas eram obrigadas a oferecer os serviços pósvenda. A leis permitiam também às montadoras possuírem centros de serviços automotivos, com peças originais, informações técnicas, treinamento adequado etc., e não estender esses benefícios aos revendedores. Ao contrário do que ocorre nos Estados Unidos, a lei favorecia as montadoras. Dava muito poder a elas e criava problemas de concorrência, prejudicando o consumidor (BOHMAN; ROSENBERG; STENBRIK, 2003, CHANARON; JULLIEN, 1999).

Em 2002, essas leis foram revistas, e em outubro do mesmo ano passou a vigorar o novo Regulamento da Distribuição de Automóveis na Europa, em substituição à 1475/95. O texto publicado pela Comissão Européia, sob o título "Colocando o Consumidor na Posição de Comando", teve como ponto de partida corrigir os problemas de concorrência criando uma estrutura na qual a concorrência de preços pudesse funcionar mais eficazmente $\left(\right.$ BLOCK...,2002) ${ }^{10}$.

A nova lei apresenta uma revisão das regras de exclusividade e seletividade. Pelas novas regras, as montadoras terão agora que escolher entre a distribuição Seletiva, (subdividida em Seletiva Qualitativa e Seletiva Qualitativa Quantitativa) e Exclusiva. No caso da escolha por distribuição Exclusiva, as montadoras poderão continuar a demarcar territórios exclusivos para ação de suas revendas, no entanto, os revendedores poderão repassar seus carros para revendedores não autorizados, que, por sua vez, poderão vender em qualquer país da União Européia. Na distribuição Seletiva, qualquer varejista que se adequar aos padrões exigidos pelas montadoras (showroom, qualificação do pessoal etc.) tem o direito de ser selecionado e

\footnotetext{
${ }^{10}$ As informações abaixo sobre a nova regulamentação de distribuição de veículos na Europa foram obtidas de um estudo elaborado pelo ICDP (International Car Distribution Programme). BLOCK exemption: novas regras do setor de distribuição europeu começam em outubro. Disponível em: 〈http://www.fenabrave.org.br/localiza $\rangle$. Acesso em: 01 jun. 2002.
} 
suprido de mercadorias para vender. Esses revendedores têm o direito de vender para os consumidores de qualquer país da União Européia.

A nova regulamentação acaba com a obrigatoriedade dos revendedores de oferecem serviços no mesmo local de vendas. Eles agora estão livres para escolher entre oferecer apenas instalações para vendas, ou apenas instalações para serviços, ou para ambos. Por isso, a nova regulamentação identifica dois tipos básicos participantes: distribuidores, que vendem carros, e oficinas autorizadas, que oferecem peças, serviços e consertos. Acordos diferentes terão que ser estabelecidos para cada um. Outro ponto a ser destacado é que deixa de haver as restrições às franquias multi-marcas, o que, em tese, deve aumentar a competição entre as marcas. Assim, segundo Bohman, Rosenberg e Stenbrik (2003), esse tipo de franquia deve se proliferar e as montadoras terão que negociar com os revendedores formas de manter a individualidade das marcas, como exigir showrooms e força de vendas separados para cada marca. No entanto, até o momento, trata-se de suposição e, em função da situação particular da Europa quanto à nova legislação, será necessário algum tempo para que o quadro da distribuição se defina.

Essa mudança nas leis deverá alterar, nos próximos anos, a estrutura de canais de distribuição na Europa (CHANARON; JULLIEN, 1999; BUZZAVO; VOLPATO, 2001; BOHMAN, ROSENBEGER; STENBRINK, 2003). Buzzavo e Volpato (2001) acreditam que essas mudanças podem levar as montadoras de uma gestão tática para uma gestão mais estratégica da distribuição. Ou seja, as montadoras devem buscar outras estratégias e lançar mão de canais alternativos de distribuição. Buzzavo e Volpato (2001) esperam também, a exemplo do que já vêm ocorrendo em outros setores, que as mudanças nas leis desencadeiem um processo de experimentação de formatos menos rígidos de distribuição de carros na Europa.

De qualquer maneira, a nova regulamentação reduz o poder das montadoras sobre a rede de distribuição e deve trazer maior concorrência ao setor na Europa.

\subsubsection{A distribuição de veículos no Japão}

A distribuição de veículos no Japão é caracterizada pelo grande controle que as montadoras têm sobre a rede de distribuição: as montadoras possuem revendas e têm participação no capital de quase a metade de seus revendedores (NISHIMURA; MORITA, 2002). 
O varejo de carros novos é concentrado, quando comparado com os Estados Unidos e Europa. O número de revendas é reduzido, sendo que cada revenda possui várias lojas. Em 1999, por exemplo, a Toyota contava com cerca de 300 revendedores, que juntos somavam cerca de 5.000 lojas (Nishimura e Morita, 2002). O reduzido número de revendas tem gerado uma forte ligação entre revendedores e montadoras. As montadoras participam com assistência técnica, tratamento preferencial com relação a pagamentos, suporte estratégico e de gestão (Nishimura e Morita, 2002).

As maiores montadoras japonesas se utilizam de multi-canais para ofertar seus modelos para o consumidor final. Apesar de haver uma certa segmentação dos produtos que são disponibilizados por canais diferentes, acontece freqüentemente de um mesmo produto ser oferecido por dois ou mais canais. Isso gera uma intensa concorrência entre os vários canais de uma mesma montadora (NISHIMURA; MORITA, 2002; BUZZAVO; VOLPATO, 2001).

Uma característica marcante do sistema de distribuição de carros novos no Japão é a venda de porta-em-porta (NISHIMURA; MORITA, 2002; BUZZAVO; VOLPATO, 2001). No entanto, nos últimos anos ele tem gradativamente cedido espaço para as vendas realizadas nas revendas. São dois os motivos alegados para isso: o alto custo do sistema e as mudanças no estilo de vida dos japoneses dificultando as visitas dos vendedores (NISHIMURA; MORITA, 2002). Outro fato a ser destacado é que cerca de $50 \%$ das vendas de carros novos no Japão são feitas sob encomenda (build-to-order) (NISHIMURA; MORITA, 2002).

Normalmente as revendas oferecem os serviços de manutenção junto com o showroom, embora não exista uma imposição legal para isso (BUZZAVO; VOLPATO, 2001). As revendas possuem exclusividade territorial para atuarem, porém, as lojas não são necessariamente exclusivas de uma única marca ou montadora. Elas são selecionadas segundo critérios estabelecidos pelas montadoras. A distribuição é exclusiva e seletiva, no entanto, Buzzavo e Volpato (2001) ressaltam que não existem regras rígidas quanto a isso como ocorre na Europa.

A regulamentação do setor é bem menos rígida que nos Estados Unidos e na Europa. Ressaltam-se os seguintes pontos (BUZZAVO; VOLPATO, 2001): 
- as revendas têm o direito exclusivo de vender o produto no território demarcado. A venda fora da região demarcada traz perdas de comissão para a revenda;

- não existe cláusula de exclusividade;

- as montadoras podem vender diretamente para o consumidor final;

- as revendas não são obrigadas a oferecerem serviços no mesmo local que o showroom,

- não existe proibição aos revendedores de repassarem seus produtos para sub-revendas;

- não existe proteção legal para os revendedores contra rompimento de contrato injustificado pelas montadoras;

- não há obrigatoriedade legal das revendas oferecerem vendas e serviços de forma integrada.

Devido à pouca regulamentação do setor, Nishimura e Morita (2002), acreditam que as montadoras japonesas terão menos dificuldade em promover melhorias nas suas redes de distribuição do que as montadoras nos Estados Unidos.

2.2.2 A crise no sistema de distribuição de carros novos

Nesses mercados analisados, principalmente nos Estados Unidos e Europa, o sistema de distribuição baseado em redes de franquias exclusivas de cada marca foi construído de forma gradual, com revendas sendo acrescentadas, porém, de maneira descoordenada (MERCER, 2003). Nishimura e Morita (2002) advogam que, num panorama de estabilidade, o sistema de distribuição de veículos tinha uma razão de ser, na medida em que ele contribuía para a performance do sistema como um todo - desenvolvimento, produção e venda. Uma vez que as montadoras passaram a ter altos custos de desenvolvimento, de equipamentos e de pessoal, elas priorizaram o processo de produção em detrimento do sistema de distribuição. Assim, durante a década de 1980 e parte da década de 1990, as montadoras adotaram novos modelos de organização da produção, melhoraram a qualidade de seus produtos e processos e diversificaram produtos.

Para Chanaron e Jullien (1999), parte do desinteresse pela distribuição até meados da década de 1990, pode ser explicada também pela demanda maior que a oferta de veículos. Assim, os problemas concernentes à distribuição, como custo, ineficiência, qualidade etc., ficavam em segundo plano, uma vez que eram absorvidos em função do excesso de demanda. 
Os aspectos regulatórios também contribuíram para essa acomodação quando à distribuição. $\mathrm{Na}$ Europa, a antiga legislação favorecia as montadoras, dando a elas grande controle sobre o varejo de carros novos, além de criarem um ambiente onde a competição entre revendedores e montadoras era limitada. Dessa forma, para as montadoras, as margens obtidas com os serviços pós-venda e peças de reposição (gráfico 2.1) compensavam a ineficiência do sistema. Nos Estados Unidos, embora mais favorável aos distribuidores, a legislação restringe as possibilidades de mudanças estruturais e dificulta a ação das montadoras sobre a rede de distribuição, criando uma grande inércia no sistema (MERCER, 2003).

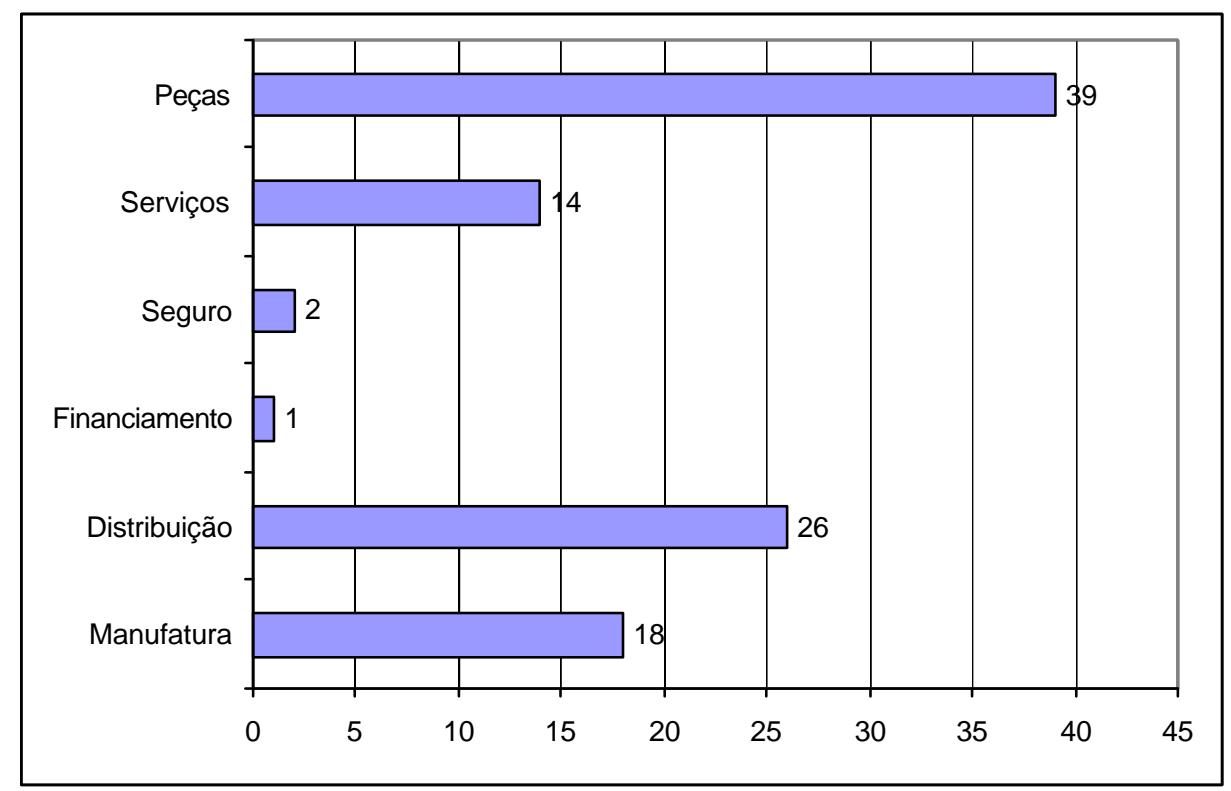

Gráfico 2.1 - Fontes do lucro bruto da indústria automotiva na Europa em 2000.

Fonte: Adaptação de Bohman, Rosenberg, Stenbrik (2003, p.136)

Porém, tanto nos Estados Unidos quanto na Europa, nos últimos anos, devido às crescentes pressões do mercado, as margens de lucro provenientes das vendas de carros novos vêm sendo reduzidas e as montadoras estão necessitando das margens extras que um sistema de distribuição mais eficiente poderia trazer ${ }^{11}$ (MERCER, 2003).

Diante das novas condições de mercado, a estrutura do sistema de distribuição tornou-se cara e pouco lucrativa (MERCER, 1994; HOFFMEISTER, 1995; CHANARON; JULLIEN, 1999).

\footnotetext{
${ }^{11}$ Apesar da ênfase que tem recebido recentemente, a importância da distribuição enquanto elemento de vantagem competitiva já era reconhecida desde há muito no setor automotivo. Loubet (1995 apud CHANARON; JULLIEN, 1999, p.339) aponta a superioridade do sistema de distribuição como um dos fatores de sucesso da Citroën durante a década de 1930. Nota também que após a II Guerra Mundial, as montadoras tiveram que reconstruir suas redes de distribuição antes mesmo de restaurarem a produção.
} 
Mercer (1994) estima que somando as margens e incentivos aos revendedores, os bônus e outras despesas, a distribuição representa $30 \%$ do preço total do carro para o consumidor. Ela também é ineficiente no atendimento aos clientes em termos de qualidade de serviços e preços e variedade de produtos requerida pelos consumidores, apesar das revendas normalmente trabalharam com altos estoques (MERCER, 1994; CHANARON; JULLIEN, 1999).

Mercer (1994) argumenta que a principal causa dessa estrutura ter se tornado obsoleta é que as razões que justificaram o seu surgimento e consolidação no passado não existem mais:

- o nível de qualidade e confiabilidade dos veículos aumentou significativamente não exigindo a mesma freqüência de manutenção do passado. Isto implica uma menor necessidade de pontos de reparo;

- formas de distribuição direta, antes economicamente inviáveis, começam a ser concebidas;

- os consumidores têm outras fontes de informação disponíveis sobre veículos, como revistas especializadas e sites de comércio eletrônico que trabalham só com informações de veículos e reduzem a importância da revenda como fonte provedora de informação;

- o fortalecimento das marcas que reduziu a importância da credibilidade dos comerciantes locais na negociação de veículos;

Outro importante fator a ser considerado e que vem contribuindo para o aprofundamento da crise no setor é o surgimento de outros atores que competem diretamente com as revendas. Entre eles estão: a) os prestadores de serviços como as redes especializadas em manutenção e reparo, que oferecem serviços especializados a preços competitivos (por exemplo, Midas, Sppedy, Goodyear, Firestone, Bosch); b) os centros de reparo existentes nos supermercados e shopping centers; c) as oficinas de postos de gasolina (MERCER, 1994; CHANARON; JULLIEN, 1999).

Esses novos atores têm trazido grande impacto na rede de distribuição, pois, conforme apontam Chanaron e Jullien (1999), com a erosão das margens de lucro na venda de carros novos, as revendas precisam compensar suas perdas com outras atividades, como os serviços de pós-vendas. Assim, manutenção e reparo tornaram-se essenciais à sobrevivência da revenda. Ocorre que as revendas acabam perdendo clientes para as redes especializadas de reparo e manutenção quando a garantia do veículo termina. 
O aumento da complexidade dos veículos também é um outro fator que deve ser considerado nesta análise. Devido à complexidade dos veículos, há a necessidade constante de investimentos em equipamentos especiais de diagnóstico e de maior qualificação e treinamento de pessoal. Esses recursos são caros e estão se tornando inviáveis para os distribuidores pequenos (WOMAK; JONES; ROOS, 1992; MERCER, 1994; CHANARON; JULLIEN, 1999). Esse fator aliado à menor necessidade de manutenção dos veículos e à retração da demanda por carros novos sugerem que não há mais escala suficiente no nível de cada revenda para suportar todas as funções em um só lugar; fato esse que, na visão de alguns autores, coloca em xeque os princípios básicos dessa estrutura: a exclusividade e a integração de funções (MERCER, 1994; HOFFMEISTER, 1995; CHANARON; JULLIEN, 1999).

Retração da demanda, novos competidores e novas tecnologias são fatores que vêm desencadeando uma série de ações tanto por parte das montadoras quanto do varejo no sentido de se adaptarem às novas condições de mercado. A seguir serão apresentadas de forma geral as principais ações do varejo e das montadoras. O caso específico do Brasil será discutido no item 2.2.3.

\subsubsection{A reação do varejo}

As inovações no varejo de carros novos estão correndo de forma lenta, tanto nos Estados Unidos quanto na Europa (MERCER, 1997).

Como em outros setores econômicos, a maior parte das iniciativas de inovação está vindo de empresas que estão fora da indústria tradicional, que no caso são as montadoras e seus distribuidores (MERCER, 1997; NISHIMURA; MORITA, 2002). É o caso, por exemplo, da Car Max, uma cadeia nacional de revendedores de carros que é uma subsidiária da Circuit City, um grande varejista americano de aparelhos eletrônicos.

Um dos mais sérios problemas enfrentados pelas redes de distribuição é a falta de escala que justifique a integração de funções em um mesmo local. No sentido das revendas recomporem suas as margens de lucros e obterem ganhos de escala, alguns movimentos foram observados na década de 1990: o surgimento das franquias multi-marcas (revendas com várias marcas), o surgimento de redes nacionais de revendedores e o surgimento dos Auto-Malls . 
Os Auto-Malls apareceram nos Estados Unidos e consistem na localização de vários showrooms de várias marcas num mesmo espaço geográfico. As lojas são independentes. Esse arranjo traz algumas vantagens para os consumidores como concentrar em um mesmo lugar marcas concorrentes, facilitando a comparação entre elas. Nishimura e Morita (2002), no entanto, questionam a eficácia desse arranjo em ser bem sucedido quanto ao ganho de escala, uma vez que as lojas são independentes e não compartilham recursos de forma coordenada.

As grandes cadeias nacionais de revendedores são outro arranjo que se prolifera nos Estados Unidos. Elas são formadas através de fusões e aquisições de pequenos revendedores. A mais proeminente é a Autonation que possui cerca de 400 lojas em 18 estados americanos (NISHIMURA; MORITA, 2002). Além de carros novos, ela comercializa carros usados e possui também locadoras de veículos. Os preços dos carros (novos ou usados) são fixos e vários modelos de várias montadoras são oferecidos no mesmo local (ou site) (NISHIMURA; MORITA, 2002). Outras cadeias importantes são a Car Max, a Sonic e a United Auto. Devido à escala de vendas que essas cadeias têm, elas possuem forte poder de negociação com as montadoras. Nishimura e Morita (2002), no entanto, também questionam o sucesso dessas cadeias. Eles argumentam que um dos problemas é o fato dessas cadeias adquirirem novas lojas sem promoverem as alterações gerenciais necessárias para coordenar as atividades entre as diferentes unidades.

Outra forma de varejo que está se proliferando nos Estados Unida é a de franquias multimarca. Mudanças de comportamento do consumidor com relação à lealdade da marca e à forma de comprar têm contribuído para isso. Grande parte dos consumidores americanos preferem a situação de poderem ir a um só lugar e escolher entre diversas marcas de veículos (one stop shopping) (HOFFMEISTER, 1995; MERCER, 1994), como já fio observado em outros setores econômicos.

As montadoras têm buscado formas de impedir a proliferação desse tipo de revenda, alegando uma deterioração da marca e da qualidade dos serviços prestados ao consumidor. No entanto, o estudo de Hoffmeister (1995) sugere que a qualidade do serviço está associada ao tamanho da franquia: quanto maior a revenda, melhor tende a ser a qualidade dos serviços oferecidos. Junta-se a isto, a tendência atual dos consumidores, sobretudo os mais jovens, de serem mais 
fiéis às revendas do que às marcas ${ }^{12}$. $\mathrm{O}$ estudo conclui portanto que o consumidor tende a retornar à revenda onde foi melhor atendido, independente da marca de carro comercializada. Esse mesmo estudo aponta, no entanto, uma dificuldade das franquias multi-marcas: as competências necessárias. Segundo Hoffmeister (1995), para que esse tipo de revenda seja bem sucedida é necessário acumular várias competências simultaneamente como saber sobre vários produtos, ter uma oficina capaz de atender a diversidade de marcas etc., uma situação difícil de ser alcançada e que deve limitar a proliferação desse arranjo.

\subsubsection{A Reação das Montadoras}

As montadoras estão reagindo através de três estratégias principais:

A primeira consiste em racionalizar a estrutura de distribuição existente e buscar credibilidade junto ao consumidor (MERCER, 1994; JULLIEN, 1998; CHANARON; JULLIEN, 1999). Com isso, as montadoras esperam tornar suas redes de distribuição mais competitivas. Entre as principais ações observadas estão:

- a redução do número de revendas: as montadoras estão revendo a antiga estratégia de aumentar o número de revendedores para obter maior cobertura de mercado e market share (BUZZAVO; VOLPATO, 2001). Elas estão se movendo para uma redução drástica do número de revendas, eliminando as pouco lucrativas e que não atingem os índices requeridos de satisfação do consumidor (MERCER, 1994) ou aquelas que não têm equipamento e pessoal treinado (CHANARON; JULLIEN, 1999). O principal objetivo é reduzir a competição entre os revendedores da mesma marca e obter economia de escala (BUZZAVO; VOLPATO, 2001);

- buscar uma uniformização da aparência das revendas: como o design e qualidade dos automóveis tem se equiparado, as montadoras estão buscando associar a marca vendida ao local da venda. As montadoras querem, assim, que suas revendas fiquem parecidas (HOFFMEISTER, 1995);

- a assistência aos revendedores para que eles aumentem a sua lucratividade: as montadoras estão colaborando com seus revendedores na adoção das "melhores práticas" em vendas, manutenção, reposição de vendas, como forma de torná-los mais competitivos (MERCER, 1994);

\footnotetext{
${ }^{12}$ Sobre os diversos tipos de multifranquias e seus impactos sobre a revenda ver Hoffmeister (1995).
} 
- a implementação de programas de satisfação do consumidor (MERCER, 1994);

- a implementação de programas de fidelização: procurar estabelecer relações duradouras com os clientes. Isto inclui além dos pacotes de viagem, cartões de créditos, a venda contínua de serviços suplementares (MERCER, 1994; HOFFMEISTER, 1995);

- o incentivo às vendas por leasing: é uma forma de manter o consumidor mais próximo à montadora e aumentar a previsibilidade das vendas (MERCER, 1994; HOFFMEISTER, 1995);

- o aumento do tempo de garantia: é sabido que uma vez finda a garantia, os consumidores tendem a desaparecer das revendas. Assim, essa é uma forma de manter o consumidor (CHANARON; JULLIEN, 1999);

- o investimento nos serviços de manutenção: é um dos fatores de lealdade do cliente. Esse é um dos aspectos mais importantes, pois os serviços de manutenção e reparo, como dito anteriormente, sofrem concorrência direta das redes especializadas em manutenção e reparo (MERCER, 1994; CHANARON; JULLIEN, 1999);

- a oferta de uma maior quantidade de serviços por produto: oferecer informação, oportunidade de customização, financiamento, garantias, socorro e outros serviços suplementares de forma contínua, ao longo de toda a vida do veículo (HOFFMEISTER, 1995; JULLIEN, 1998; CHANARON; JULLIEN, 1999);

Essa estratégia das montadoras de otimizar a estrutura existente possui certas limitações e esbarra em algumas questões importantes. Em primeiro lugar, é preciso um maior envolvimento da montadora com os revendedores. No entanto, as relações entre montadoras e revendedores são historicamente conflituosas. São muitas as resistências a serem vencidas, tanto do lado dos distribuidores como das montadoras. Certamente, as montadoras terão de rever muitas das suas práticas junto aos revendedores, como por exemplo, o estabelecimento de cotas, estoques etc. (MERCER, 1994). Mudanças dessa natureza são lentas e difíceis de serem implantadas. Em segundo lugar, os investimentos são altos: melhoria de equipamentos, treinamento de pessoal, diversificação de serviços. O que se questiona é se as revendas terão condições de arcar com a parte do investimento que lhes cabe e o quanto as montadoras estão dispostas a investir (MERCER, 1994; CHANARON; JULLIEN, 1999). Em terceiro, há a presença de novos atores. As cadeias de serviços de manutenção e reparo têm melhores equipamentos, serviços diversificados e melhores do que as oficinas das revendas. A questão aqui é se as revendas terão condições de investirem continuamente em equipamento, 
treinamento e diversificação de serviços para competirem com as redes especializadas (MERCER, 1994; CHANARON; JULLIEN, 1999).

A segunda estratégia, mais agressiva, consiste no aumento de controle dos revendedores através da integração vertical da distribuição. Essa estratégia traria, em tese, duas vantagens para as montadoras: primeiro, garantiria as margens na venda de carros novos e no mercado de reposição e serviços. Segundo colocaria as montadoras em posição privilegiada para reestruturar (ou melhorar o desempenho) da rede de distribuição (BOHMAN; ROSENBERG; STENBRIK , 2003).

Algumas experiências foram feitas nesse sentido. O exemplo mais notório é o da Ford. No final da década de 1990, a Ford iniciou um projeto piloto e adquiriu revendas em vários mercados regionais nos Estados Unidos. A experiência, no entanto, fracassou e a Ford começou a se desfazer de suas lojas (KNUPFER, RICHMOND E ARK, 2003; BARRETO FILHO, 2002a, 2002b). Isto porque, segundo Knupfer, Richmond e Ark (2003), o desempenho das lojas dirigidas pela montadora foi inferior a dos revendedores independentes. O motivo alegado foi a falta das competências e dos conhecimentos dos mercados locais necessários para operar as revendas de forma lucrativa. A experiência, todavia, não deve ser descartada e, certamente, algum aprendizado deve ter ocorrido tanto da parte dos revendedores como da montadora.

Ealey e Bermúdez (2000) já alertavam que o ingresso das montadoras nas atividades a jusante é uma questão complexa: há de se considerar cada mercado separadamente (venda de carros novos, compra e venda de usados, distribuição de peças, assistência técnica, seguros etc.), alguns dos quais bastante fragmentados; as tecnologias emergentes em cada um e as capacidades das montadoras em adquirir as novas competências necessárias para operar o negócio do varejo, o que demanda tempo e investimentos.

Neste ponto, além da questão da competência, outros aspectos devem ser considerados na análise dessa estratégia. Um dos mais importantes é a questão do conflito de canal. Há uma tendência à desconfiança dos revendedores independentes quanto às lojas próprias e uma reação contrária é esperada. Segundo relatam Nishimura e Morita (2002) a GM voltou atrás de sua decisão de adquirir revendedores depois de uma reação contrária da sua rede franquias. 
Outro aspecto que não pode ser ignorado quanto se trata de possuir lojas próprias ou uma rede de franquias independentes diz respeito aos problemas de incentivo e motivação (SAPPINGTON, 1991). Quais seriam os níveis adequados de incentivo e motivação a serem providos aos gerentes das lojas próprias para que o desempenho delas fosse superior ou igual ao dos revendedores independentes? Isto porque, uma importante vantagem do sistema de franquia refere-se ao fato de que, a partir do contrato de divisão dos riscos, o franqueado possuiria um maior incentivo - quando comparado à atuação de um gerente de loja própria em desempenhar suas atividades da melhor forma possível, contribuindo assim para o sucesso não apenas de sua unidade, mas de toda a rede (LAFONTAINE, 1992).

Há também o aspecto regulatório. Em muitos estados americanos, as leis estaduais proíbem as montadoras de possuírem revendas. Existem também outras leis que protegem os revendedores de novos entrantes (EALEY; BERMÚDEZ, 2000; KNUPFER; RICHMOND; ARK, 2003).

Apesar das dificuldades e do aparente fracasso da Ford, essa estratégia não deve ser descartada pelas montadoras. Em sua análise sobre os reflexos da nova regulamentação do setor de distribuição de veículos na Europa, feita no XIII Congresso da Fenabrave de agosto de 2003, Buzzavo (apud VISÃO...,2003) afirma que "algumas montadoras acreditam que o melhor caminho para o varejo é o envolvimento direto, ou seja, se tornarem donas de concessionárias. Este é o caso particular de algumas marcas na França e na Europa".

A estratégia requer altos investimentos por parte das montadoras para a compra de revendedores e, na visão de Bohman, Rosenberg e Stenbrik (2003), seria indicada apenas para marcas fortes que possuem altos volumes de vendas e com margens que garantam um retorno que compense os riscos e investimentos envolvidos.

A terceira estratégia consiste na venda direta através de um novo canal de venda: os sites de comércio eletrônico de carros das próprias montadoras. A Ford, a GM e outras montadoras desenvolveram os seus próprios formatos de negócio na Internet e atualmente vendem para os consumidores através de seus próprios sites (NISHIMURA; MORITA, 2002). Na maioria dos casos, não se trata de comércio eletrônico puro. Em grande parte, os sites são prestadores de serviços onde o cliente configura, localiza e obtém o preço do carro. Para comprar, porém, necessita da participação dos revendedores no processo. 
Esse novo canal aproxima as montadoras dos consumidores finais. Torna possível a elas conhecer melhor seus clientes através de sistemas de gerenciamento do relacionamento com o cliente (CRM), o que poderá ter implicações no processo de desenvolvimento de novos produtos. A venda direta traz ainda a possibilidade de um aumento do percentual de veículos produzidos sob encomenda, reduzindo assim significativamente os níveis de estoques no canal.

Porém, são várias as dificuldades a serem transpostas pelas montadoras que o estão implantando. Elas vão desde a habilidade que essas empresas têm ou não de se organizarem apropriadamente, de gerenciar as mudanças e as ligações de seus negócios tradicionais com o e-business, de obter uma infraestrutura correta (com pessoal qualificado, instrumentos, cultura e processos) (FREELAND; STIRTON, 2000 apud ZILBER, 2002, p. 107) ${ }^{13}$, até a capacidade de gerenciar os conflitos de canal. Esse conflito poder ser minimizado através de algumas ações como a segmentação por produtos, a segmentação por clientes, a redefinição das responsabilidades do revendedor e o direcionamento das vendas para o distribuidor (WEIL; VITALE, 2001 apud ZILBER, 2002, p. 75) ${ }^{14}$.

Há ainda os impedimentos legais. Em muitos mercados as montadoras não podem vender diretamente para o consumidor final, como é o caso dos Estados Unidos e do Brasil.

Em resumo, as montadoras estão buscando formas de aumentar o controle sobre a distribuição, seja otimizando o canal existente, seja integrando a distribuição na cadeia de suprimentos, adquirindo revendas ou vendendo diretamente para o consumidor final através da Internet.

\footnotetext{
${ }^{13}$ Freeland, G. D.; Stirton, S. Organizing for e-commerce. Discussion paper to Boston Consulting Group Inc. Disponível em: http://www.bcg.com/publications/files/organizing\%20Ecommerce\%20Apr\%2000.pdf

${ }^{14}$ Weil, P; Vitale. M. Place to space: migrating to e-business models. USA : Harvard Business Publishing Corp., 2001
} 


\subsubsection{A proposta de reestruturação da distribuição}

Para Mercer (1994), embora a racionalização da estrutura atual seja necessária, ela se constitui em uma estratégia de curto prazo. Assim, mudanças mais profundas devem ser pensadas no longo prazo, em função, principalmente, da entrada de novos agentes no mercado.

Mercer (1994) propõe que o caminho a ser seguido é a reestruturação total do sistema de distribuição. Essa reestruturação seria a desagregação de funções, ou seja, focalizar cada elemento da distribuição separadamente. A principal vantagem seria a obtenção de economia de escala, através da concentração das vendas de carros novos em uma grande revenda, da concentração da venda de carros usados em outro lugar e feita por especialistas, da separação da manutenção e distribuição de peças de reposição, ambas também feitas por especialistas. Ou seja, buscar-se-ia uma nova divisão do trabalho no canal com uma especialização dos seus agentes. As atividades ficariam mais focadas e seria possível também desenvolver um marketing mais eficiente. Seria assim necessária uma revisão do formato do negócio da revenda.

A desagregação de funções pode assumir várias formas: 1) as montadoras venderiam diretamente para o consumidor e utilizariam uma rede independente de serviços para manutenção e reparo; 2) as montadoras usariam uma rede de revendedores como intermediários, mas entregariam o veículo diretamente ao consumidor; 3) carros usados poderiam ser negociados em locais especializados nesse tipo de negócio e de maior credibilidade junto ao consumidor que as revendas; 4) serviços de manutenção e distribuição de peças poderiam ser feitos também por outros agentes especializados que atenderiam várias marcas.

Por essa proposta haveria, na realidade, múltiplos canais e formatos, ou seja, combinações distintas de pontos de vendas, oferta de serviços e processo de negócio dentro de uma definição geral de canal, coexistindo para satisfazer diferentes segmentos de mercado.

Chanaron e Jullien (1999) também acreditam que as vantagens de desagregação de funções são claras para os serviços de manutenção, vendas de carros usados no que se refere aos ganhos de escala e aprendizado que podem ser alcançados. Junta-se a isto o fato dos 
consumidores, seguindo tendência observada em outros setores, estarem buscando serviços especializados.

Essa estratégia de desagregação esbarra em pelo menos quatro importantes fatores. $\mathrm{O}$ primeiro é a própria inércia do sistema atual. Segundo, seria preciso mudanças na regulamentação que rege as relações entre montadoras e revendedores. Vendas diretas, por exemplo, não são permitidas por lei tanto nos Estados Unidos como no Brasil. Terceiro, as próprias montadoras podem ter ressalvas ao tipo de reestruturação a ser feita, dado que elas se beneficiam de um elemento muito importante do sistema: a exclusividade da marca. Quarto, as montadoras teriam que abrir mão de parte do controle sobre a distribuição.

Chanaron e Jullien (1999) advogam que as montadoras terão provavelmente que aceitar a desagregação nas funções que são melhores atendidas por fornecedores independentes. Para eles, já há uma tendência na direção de uma especialização de serviços de manutenção e esse processo é fruto de situações de mercado e não está sob o controle das montadoras. É, na realidade, um dos fatores que está pressionando as montadoras a reverem seus sistemas de distribuição.

Uma questão que se coloca neste ponto é se as montadoras manterão a mesma posição de poder que elas ocupam hoje, ou cederão a sua posição de liderança do canal a grandes grupos de revendas ou a novos atores como as redes especializadas de manutenção e distribuição de peças (MERCER, 1994; CHANARON; JULLIEN, 1999)?

Vários fatores não estão sob o controle das montadoras, como o surgimento de novos competidores, o processo de concentração do varejo, o surgimento de novos intermediários como os sites independentes de comércio eletrônico.

A partir das observações das iniciativas dos vários atores envolvidos a jusante na cadeia automotiva, Chanaron e Jullien, (1999) traçam três possíveis cenários (figura 2.1).

- Cenário 1: Segmentação. Novos atores estão ocupando mercados nos quais as montadoras e suas redes de distribuição não têm (ou têm pouca) proteção legal. Esse processo é irreversível e não está sob controle das montadoras;

- Cenário 2: Integração. Seria uma reação das montadoras às perdas de mercado devido à entrada dos novos atores. As montadoras devem tentar reintegrar as funções a jusante e 
aceitar um certo grau de especialização dentro das suas próprias redes de distribuição. Nesse caso, as montadoras recuperariam o papel central;

- Cenário 3: Coordenação: O caráter irreversível da especialização sugere a emergência da função de coordenação para a distribuição. A questão é quem vai assumir esse papel. As montadoras podem monopolizar a interface com os consumidores, mas devem renunciar às outras funções e organizá-las em parcerias com outros agentes, ou o papel de coordenação vai ficar com outros atores.

Esses cenários não são mutuamente excludentes, e provavelmente haverá diferenças entre as montadoras e de país para país devido às peculiaridades históricas e institucionais de cada local (CHANARON; JULLIEN, 1999).

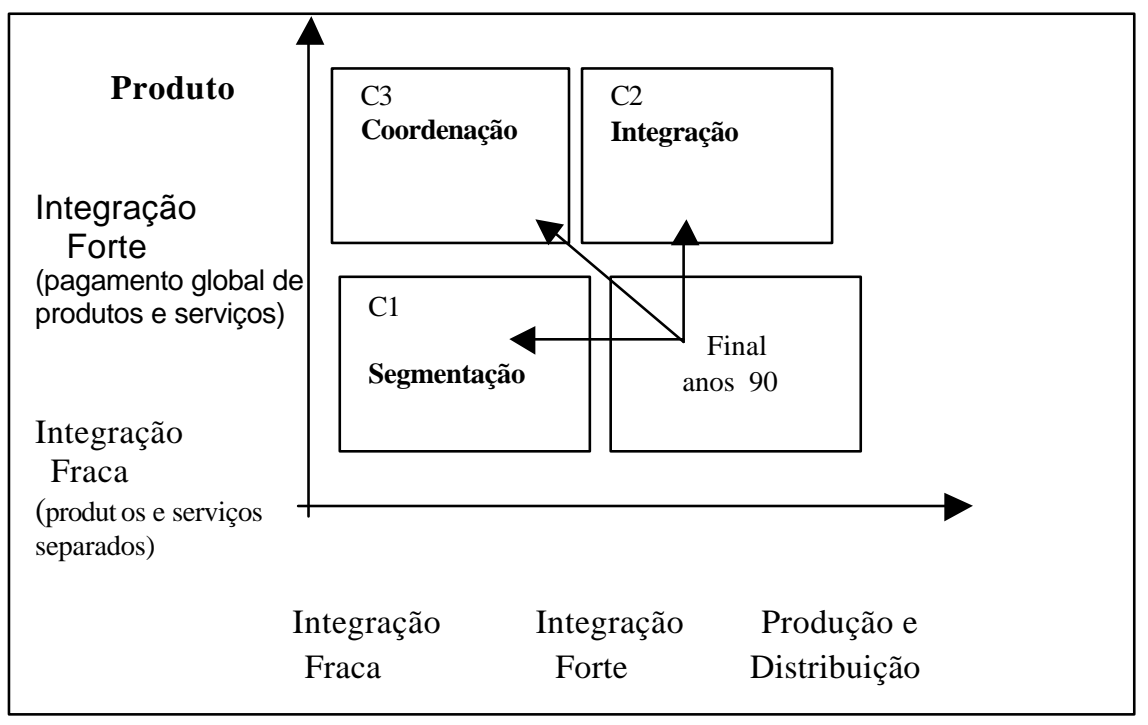

Figura 2.1 - Cenários para o futuro da distribuição de veículos. Fonte: Chanaron e Jullien (1999, p. 358).

\subsubsection{A distribuição de carros novos no Brasil}

No Brasil, a distribuição de carros novos é feita através de dois canais de distribuição: o canal direto, que são as vendas das montadoras pela Internet; e através das redes de concessionárias. 
Cada montadora possui a sua própria rede, sendo que cada concessionária é um ponto de venda exclusivo de cada marca (ou montadora). No nível de cada concessionária aparecem normalmente integradas cinco funções principais: venda de carros novos, venda de carros usados, serviços, distribuição de peças e financiamento.

Existem cerca de 2200 concessionárias de carros novos no país. Em sua maioria (45,5\%), são empresas familiares de pequeno porte, que comercializam até 20 unidades/mês (tabela 2.3). São empresas independentes e existe muita diferença no atendimento e na apresentação de cada concessionária. Em 2003 elas comercializaram 1,19 milhões de carros novos (INFORMATIVO FENABRAVE, 2004)

Tabela 2.3 - Porte das concessionárias segundo o número de carros novos comercializados por mês.

Porte das concessionárias

Pequena (até 20 un/mês)

45,5

Média (21 a 50 un./mês)

Média Grande (51 a 100 um./mês)

11,9

Grande (101 a 400 un./mês)

Mega Dealer (acima de 401 un./mês)

0,3

Fonte: Fenabrave

Os pequenos revendedores respondem por 27,0\% do faturamento das vendas de automóveis e comerciais leves no Brasil, enquanto que os Mega Dealers, por 6,8\% (tabela 2.4). 
Tabela 2.4 - Percentual de faturamento das vendas totais de autos e comerciais leves por porte das concessionárias.

\begin{tabular}{lc} 
Porte das concessionárias & $\%$ de faturamento \\
\hline Pequena & 27,0 \\
Média & 24,8 \\
Média Grande & 18,0 \\
Grande & 23,0 \\
Mega Dealer & 6,8
\end{tabular}

A venda de carros novos foi, e ainda é, a principal fonte de lucro das revendas, segundo a Federação Nacional da Distribuição de Veículos Automotores (Fenabrave) e a Associação Brasileira de Distribuidores Volkswagen (Assobrav) (tabela 2.5). Nisso o setor difere bastante das revendas americanas e européias, locais onde a distribuição de peças e serviços é a maior responsável pelos ganhos das revendas (ver item 2.2.1).

Tabela 2.5 - Origens dos lucros das revendas no Brasil em 2001

\begin{tabular}{lc}
\hline Atividades & \% do lucro \\
\hline Veículos novos & 55 \\
Dist. partes e serviços & 25 \\
Veículos Usados & 10 \\
\hline Fonte: Assobrav &
\end{tabular}

As revendas trabalham com altos estoques de carros novos e, apesar de as montadoras venderem diretamente para os consumidores finais através de seus sites de comércio eletrônico, a maior parte das vendas são realizadas com itens disponíveis nesses estoques: na rede Volkwagen, o percentual, em volume, vendido pela rede é de $80 \%$; na rede Fiat, $86 \%$, e na rede Chevrolet, $60 \% .{ }^{15}$. No entanto, as concessionárias são os canais de entrega e de serviços de todas as vendas realizadas diretamente pelas montadoras.

\footnotetext{
${ }_{15}$ Dados fornecidos pela Volkswagen do Brasil, pela Fiat Automóveis e pela Associação dos Concessionários Chevrolet (ABRAC)
} 
As montadoras fazem exigências quando às instalações físicas (tamanho da loja), equipamento e ferramental e qualificação de pessoal.

A distribuição está baseada no sistema push. As montadoras estipulam cotas mensais de carros para as revendas. Cada montadora tem o seu sistema de cotas e o grau de participação do concessionário na determinação do mix de produtos (modelo, cor, opcionais e motorização) varia segundo a montadora.. Por causa do sistema de cotas, certos modelos e volumes de carros são impostos às concessionárias e por isso elas são obrigadas a manter em seus estoques carros com baixa demanda. As revendas fazem suas solicitações (floor-plan) através de um sistema de coleta de pedidos, específico de cada montadora. É pratica comum entre montadoras e distribuidores também as vendas casadas. As montadoras têm também políticas de comercialização de peças de reposição para as revendas.

\subsubsection{O histórico e a regulamentação da distribuição de veículos no Brasil}

No Brasil, nas primeiras duas décadas do século XX, os carros eram comercializados pelos agentes importadores - os dealers, que representavam os negócios das montadoras no Brasil. Esses agentes recebiam os pedidos, agilizavam a documentação e garantiam a entrega do produto. Concentravam-se no eixo Rio-São Paulo e não chegavam a formar uma rede distribuição. Em 1920 surgem os primeiros revendedores autorizados, depois que os primeiros carros passaram a ser montados no país com a instalação do sistema CKD - Completely Knocked Down. Por esse sistema, os carros eram importados em peças e montados no país. Além de vendas, os revendedores autorizados prestavam assistência técnica com oficina e mão-de-obra especializadas. As relações entre montadora e distribuidor passaram a ser regidas por Contratos de Concessão ${ }^{16}$, que preservavam os interesses das montadoras e controlavam os revendedores.

\footnotetext{
${ }^{16} \mathrm{O}$ contrato de concessão em matéria comercial é uma convenção que liga o fornecedor a um número limitado de comerciantes, aos quais ele reserva o direito de venda de um produto, desde que satisfaçam certas condições. O contrato de concessão implica em 3 fatores: o compromisso em fornecer produtos, a licença de marca em troca de certas obrigações, a zona geográfica assegurada por uma exclusividade. Em certos casos a concessionária tem direito sobre um símbolo, com exclusividade territorial, o que permite que ele usufrua da notoriedade da marca. A parceria entre concessionário e fabricante não passa de compromisso das exclusividades recíprocas, ficando a cargo do concessionário definir os meios para que as cotas fixadas sejam cumpridas. Para maiores esclarecimentos sobre o assunto ver Mendez e Lehnisch (1991).
} 
A partir dos anos 50, quando a produção cresceu, com os índices de nacionalidade dos veículos aumentando, as montadoras tiveram que remodelar o sistema de distribuição e acabaram revendo os contratos em vigor. A rede foi ampliada com o credenciamento de novas empresas que já comercializavam veículos importados e usados e mesmo algumas sem nenhuma tradição no ramo. Cada fabricante desenvolveu a sua própria rede de distribuição.

Para os antigos e tradicionais revendedores autorizados, os novos contratos de concessão significaram um controle ainda maior por parte das montadoras, que passaram a determinar às concessionárias os volumes de estoques a serem mantidos e os prazos de comercialização desses estoques. O zoneamento da distribuição ficava a cargo da montadora que tinha autonomia também para realizar modificações unilaterais dos contratos.

Até o final da década de 1970 não havia nenhuma lei regulando as atividades do setor. A primeira lei regulando a relação entre montadoras e concessionários foi a Lei 6.729/79 de 1979, conhecida como Lei Renato Ferrari ${ }^{17}$. A proposta de leis para regulamentar o setor e proteger os interesses dos concessionários partiu de uma associação de marcas, a Assobrav. A Associação Brasileira de Revendedores Autorizados de Veículos (Abrave), que na época era a organização que representava os interesses dos concessionários em todo país, coordenou o texto da lei. Porém, o texto original sofreu várias modificações (ítens que tratavam da defesa do consumidor, por exemplo, foram suprimidos) até ser aprovada em 1979. Os principais resultados da Lei 6.729/79 foram:

- Intitula o distribuidor de concessionário;

- Exige do concessionário exclusividade na comercialização da marca;

- Exige do concessionário a prestação de assistência técnica aos produtos objeto da concessão, inclusive quanto ao seu atendimento ou revisão;

- Inibe o término desleal de um contrato de concessão: a lei prevê em que situações pode haver a rescisão do contrato e as penalidades a que fica sujeita a parte que o rompe indevidamente;

- Inibe as montadoras de colocar mais pontos de distribuição por área do que a mesma suporta;

- Estabelece distâncias mínimas entre concessionários da mesma rede;

\footnotetext{
${ }^{17} \mathrm{O}$ texto integral da lei, bem como as alterações, está disponível em $\underline{w w w . f e n a b r a v e . o r g . b r}$
} 
- Inibe as concessionárias de atuarem fora da área demarcada: no caso do concessionário efetuar venda em outra área demarcada, este deve destinar parte da margem de comercialização ao concessionário da área do domicílio da adquirente;

- Permite aos concessionários abrir filiais, agências ou dependências secundárias, circunscritas às distâncias mínimas entre o estabelecimento de concessionários e atendidas as condições objeto de ajuste entre o produtor e a sua rede de distribuição;

- Faculta ao concessionário a participar das modalidades auxiliares de venda que o concedente promover como consórcios, planos de financiamento etc.;

- No caso de nova concessão na área demarcada, o concedente é obrigado a dar preferência ao concessionário já estabelecido;

- Dá ao concessionário o direito de cancelamento de pedido, caso ele não seja atendido no prazo fixado com o concedente;

- Permite ao concedente estabelecer quotas de veículos para o concessionário;

- Dá ao concedente o direito de exigir do concessionário a manutenção de estoques;

- Determina que os concessionários deverão vender as mercadorias ao preço fixado pelo concedente, podendo o concessionário acrescentar ao preço o valor de frete, seguro e outros encargos referentes ao envio das mercadorias;

- Determina que a margem de comercialização do concessionário na mercadoria objeto de concessão terá seu percentual incluído no preço ao consumidor;

- Veta ao concessionário a possibilidade de redução da margem percentual de comercialização;

- Especifica em que situações a montadora pode vender diretamente seus produtos. É o caso de venda à Administração Pública, Corpo Diplomático, ou para compradores especiais de acordo com quotas previamente estipuladas entre o concedente e sua rede de distribuição.

Em 1990, a Lei no. 6.729/79 foi revista e ganhou novo texto com as alterações acrescentadas pela Lei no. 8132/90. A revisão do texto foi uma imposição do governo, pois este entendia que seu conteúdo era cartorial. As alterações mais importantes foram:

- No caso de contratação de nova concessão, o concessionário já instalado na área demarcada concorrerá com os demais interessados em igualdade de condições;

- A extinção do artigo que tratava da margem de comercialização ;

- A liberação do preço de venda do concessionário para o consumidor; 
- A garantia ao consumidor do direito de compra no concessionário que melhor lhe convier, ficando o concessionário obrigado apenas à indenização do serviços de assistência técnica em garantia prestados pelo seu colega de rede situado no domicílio do comprador;

- Criou os serviços autorizados.

Mesmo a proposta de lei tendo partido das associações de marcas, a regulamentação ainda é bastante favorável às montadoras. Porém garante alguns direitos aos revendedores, como por exemplo, o término unilateral do contrato pelas montadoras. Não há, até o momento, mudanças previstas para essa lei, que possam alterar de forma significativa a distribuição como vem ocorrendo na Europa.

\subsubsection{A situação das redes de distribuição de carros novos no Brasil}

Desde o final da década de 1990 a situação do setor de distribuição de veículos novos é de instabilidade. Depois de um crescimento irregular no final dos anos 90, uma estagnação tomou conta do setor no começo dos nos 2000. Altas taxas de juros para compra de carros novos, estagnação dos salários dos brasileiros e pressão sobre os preços dos carros contribuíram para essa situação. Em 2002 o segmento teve uma retração 6,67\% (Informativo Fenabrave, 2003, 2004) (gráfico 2.2). Para 2004 havia uma expectativa de crescimento das vendas de carros novos, no entanto, ela ainda não se confirmou.

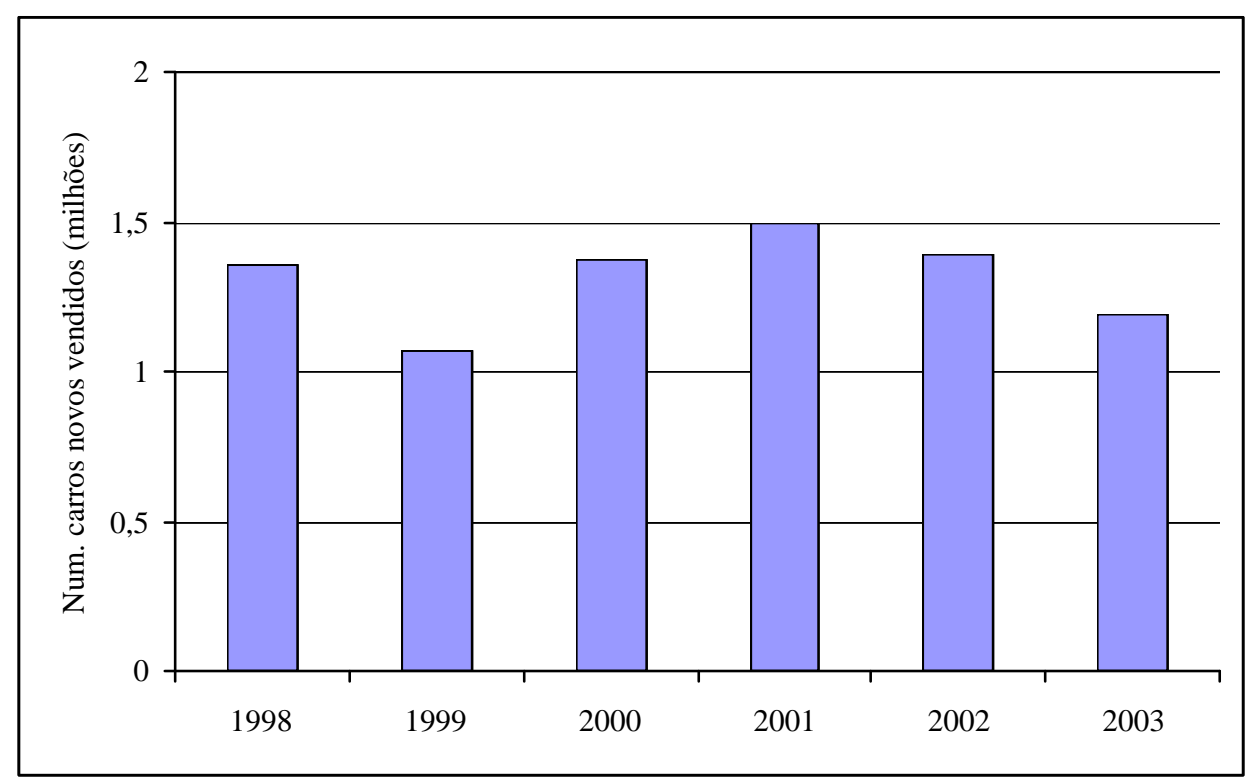

Gráfico 2.2 - Vendas de automóveis novos no Brasil Fonte: Fenabrave 
Desde o final da década de 1990, as redes de concessionárias têm sido pressionadas para reduzirem as margens de lucro na comercialização de carros novos, sua principal fonte de receitas, devido ao aumento da concorrência no mercado de automóveis no país. (ALMEIDA, 2000). As redes de concessionárias vêm enfrentando problemas financeiros. Segundo Arbix e Veiga (2001), a rentabilidade da revenda é inferior a outros segmentos da economia e da própria cadeia produtiva.

Outros problemas levantados junto a concessionários por Arbix e Veiga (2001) incluem:

- competição com a mesma marca: existe competição entre as revendas da mesma marca, o que acaba aprofundando a descapitalização das pequenas e médias revendas;

- falta de capital para promoverem as mudanças necessárias: as montadoras os obrigam a comprar veículos indesejados e peças a preços elevados, œm uma margem de lucro insignificante. Os maiores problemas estão nos altos custos de manutenção de estoques, nas áreas de ferramental, adequação de lay-out, tecnologia e capital de giro;

- falta de lideranças capazes de coordenar a renovação profissional do negócio e de encabeçar negociações mais vantajosas com as montadoras;

- alimentam incertezas quanto ao futuro do negócio.

Nas entrevistas realizadas durante a coleta preliminar de dados (ver item 3.2) junto a concessionários e entidades representativas do setor, pôde-se constatar, ainda, que as revendas se deparam com outros problemas: são mal gerenciadas; estão presas às práticas de vendas do passado, quando a demanda por carros era maior que a oferta; seus proprietários são despreparados e enfrentam problemas de sucessão; a qualidade do atendimento e dos serviços prestados é baixa e os preços praticados são altos. Além disso, os revendedores sofrem a concorrência das oficinas independentes. Uma vez terminada a garantia dos veículos, os consumidores migram para as oficinas independentes na busca de melhores preços. Um cenário parecido com o encontrado nos Estados Unidos e Europa. (ver item 2.2.1). No Brasil, um estudo realizado por Urdan e Zuñiga (2001) com 225 usuários de veículos brasileiros, mostrou que existe uma relação entre a satisfação com os serviços de assistência técnica e a sua lealdade ao fabricante do veículo, e que portanto, investir na melhoria desses serviços seria uma ação importante para revendedores e montadoras. 
No sentido de procurar reverter essa situação, as Associações de Marcas e consultores ligados ao setor ${ }^{18}$ têm proposto algumas sugestões:

- Novos formatos: Considera-se a possibilidade de novos formatos de estruturação da rede, com formação de parcerias entre as concessionárias de uma mesma marca. Uma alternativa que se discute é um compartilhamento de recursos e evitar a duplicação desnecessária de funções. Por exemplo, se uma revenda tem vocação para a comercialização e a outra para assistência técnica, poder-se-ia formar uma parceria: uma comercializando e a outra prestando assistência técnica. Com isso poder-se-ia obter redução de custos e ganho de escala, e, além disso, construir um relacionamento mais cooperativo dentro da própria rede. Outra proposta é a realização de parcerias com empresas fornecedoras de serviços automotivos como funilarias, serviços rápidos etc. (NOVOS..., 2001; ARBIX; VEIGA, 2001; ASSOCIAÇÕES...,2002);

- Novos serviços e produtos: uma das estratégias da rede para superar a crise seria o desenvolvimento de novos serviços e produtos. A oferta de serviços diferenciados aparece como um caminho para estabilizar a concessionária, fidelizar os clientes e agregar valor ao negócio da revenda ${ }^{19}$ (CRIATIVIDADE..., 2001);

- Focar no pós-venda e em reposição de pecas: é uma possibilidade para estabilizar as revendas e torná-las menos dependentes das flutuações de mercados de veículos novos. Porém, são vários os obstáculos a serem transpostos. Os maiores problemas enfrentados pelas concessionárias são os atrasos na entrega do veículo reparado, o tempo de reparo, a disponibilidade e o alto custo das peças de reposição. Para que funcione é necessário uma revisão dos processos e das políticas de estocagem de peças (PÓS-VENDAS..., 2001);

- Oferecer serviços rápidos: é uma alternativa para o aumento da rentabilidade da oficina. A idéia é aumentar a agilidade no atendimento e fugir da burocracia que atualmente ainda impera nos revendedores. Esses serviços também poderiam manter na concessionária o consumidor que tradicionalmente migra para as redes especializadas de serviços automotivos, na busca de melhor atendimento e preço. Os serviços rápidos englobam serviços de alinhamento, balanceamento, troca de pneus etc.

\footnotetext{
${ }^{18} \mathrm{O}$ site da Fenebrave dá uma boa visão das preocupações dos concessionários. As discussões giram em torno de como preservar o negócio e aumentar sua rentabilidade.

${ }^{19}$ Por exemplo: assistência técnica, com atendimento mecânico na casa do proprietário; poder abastecer o carro e fazer compras na loja de conveniência localizada dentro da concessionária; oferecer um espaço especial para crianças passarem o tempo, enquanto os pais escolhem um carro, ou aguardam o reparo do veículo na oficina.
} 
- Carros usados: é uma alternativa para melhorar o negócio, porém deve ser administrado mais profissionalmente pelos revendedores (ASSOCIAÇÕES...,2002)

As associações de marcas e a Fenabrave têm agido no sentido de dar suporte às redes em termos de gerenciamento e de capacitação dos empresários do setor. Alguns dos projetos desenvolvidos pela Fenabrave são:

- A Certificação de Qualidade de Usados: tem como objetivo agregar valor à venda de carros usados nas revendas. Através de um padrão de revisão mecânica e eletro-eletrônica dos veículos usados comercializados pela concessionária, procura-se reduzir o número de retornos para a assistência técnica. Como resultado há uma redução de custos e evita-se o desgaste com os consumidores. A certificação traria um diferencial competitivo para a concessionária. Esse programa está sendo desenvolvido em parceria com o Instituto da Qualidade Automotiva (IQA) (FENABRAVE..., 2001);

- A Universidade do Concessionário do Futuro: universidade corporativa que tem como objetivos a formação e o aprimoramento de profissionais do setor de distribuição. Os cursos oferecidos englobam formação básica em varejo, atualização contínua com temas ligados à concessionária e ao mercado automotivo. Esse programa está sendo feito em parceira com o ISAE/FGV. (UNIVERSIDADE..., 2001);

- Criação de sistemas que viabilizem a implantação CRM nas concessionárias (CONTROLE..., 2001). A ampliação do uso da novas tecnologias da informação vem sendo estimulada não só na venda de carros novos, mas também para oferecer serviços e comercializar carros usados;

- O Portal TELA: portal exclusivo para os concessionários que disponibiliza dados de mercado e desempenho da rede;

- O Peça Genérica: prevê a compra de peças de reposição diretamente das indústrias de autopeças para a rede de concessionárias associadas através do portal TELA. O objetivo é eliminar os procedimentos burocráticos de logística praticados pelas montadoras na troca e venda dos componentes e reduzir o preço das peças. Segundo a Fenabrave, não só as concessionárias e consumidores ganhariam com isso, mas também as montadoras, pois com preços mais competitivos as concessionárias poderiam atrair os clientes que se afastam das rede autorizadas depois do prazo de garantia, o que, acredita-se, traz fidelidade à marca. (PROJETO..., 2002); 
- O Guia da Concessionária Enxuta: o projeto baseia-se principalmente nos estudos do ICDP e propõe uma nova forma de operar a concessionária, mais ágil, flexível e com custos menores (CONCESSIONÁRIA ..., 2002).

O impacto dessas ações na rede de concessionárias é ainda questão em aberto. A própria capacidade da Fenabrave para coordenar esses projetos é questionável. Segundo Arbix e Veiga (2001), os revendedores ressentem-se de lideranças capazes de coordenar a renovação profissional de seus negócios e de encabeçar negociações com as montadoras em favor da rede. Sobre isso, Arbix e Veiga (2001) advogam que o fortalecimento das entidades de categoria (no caso do Brasil, Fenabrave e associações de marcas) seria aspecto importante a ser considerado, pois cabe a elas o papel de promover a cooperação na rede. Essa cooperação, segundo os autores, é um elemento importante, sem o qual será difícil sustentar as inovações e necessárias ao setor. Às entidades de categorias caberiam também defender e valorizar o negócio da revenda e acumular forças para negociações mais equilibradas com as montadoras.

\subsubsection{3 - As mudanças em curso na distribuição de carros novos no Brasil.}

As principais mudanças registradas na distribuição de veículos novos no Brasil são a concentração no varejo e o comércio eletrônico de carros novos.

A redução do número de concessionárias e a concentração de capital no varejo de carros novos está ocorrendo no Brasil desde o final da década passada (tabela 2.6). O objetivo é, como nos Estados Unidos e Europa, obter ganhos de escala e redução de custos. Esse processo tem se dado através da compra de pequenos concessionários pelas grandes revendas (FUSÔES...,2000). Assim, observa-se o aparecimento de grandes revendas com várias lojas (filiais) espalhadas geograficamente. O resultado disso, é um aumento da área de atuação de certas concessionárias. Observa-se também o surgimento de grandes grupos que operam várias marcas. No entanto, não há dados disponíveis no Brasil de quantos grupos econômicos detêm a distribuição de carros novos no país. Assim como não existem estudos que comprovem que esses novos arranjos estão se revertendo em ganhos efetivos em termos de escala e de qualidade de serviços. 
Tabela 2.6- Número de pontos de venda das redes de distribuição.

\begin{tabular}{lcc}
\hline Rede & 2000 & 2003 \\
\hline Volkswagen & 676 & 392 \\
Chevrolet & 507 & 459 \\
Ford & 351 & 301 \\
Fiat & 458 & 408 \\
Peugeot & 59 & 80 \\
Reanult & 45 & 60 \\
Toyota & - & 89 \\
Honda & 24 & 55 \\
\hline
\end{tabular}

Fonte: Fenabrave

Segundo Hessel e Vilardaga, 2000, esse processo é estimulado pelas montadoras, no entanto, a forma de atuação das montadoras não é clara. O que se observa é que as montadoras estão pressionado os revendedores, que já se encontram em situação ruim e endividados com os bancos (muitas vezes das próprias montadoras), a entregarem seus negócios a preços baixos para outros investidores indicados por elas.

Se de um lado há estímulo, de outro há também um receio por parte das montadoras de que o surgimento de grandes revendedores aumente o poder de negociação dos revendedores (SALERNO, 1997, VILADARGA, 1999, ALMEIDA, 2000). Para evitar que isso ocorra, a Ford, a GM e a Volkswagen têm procurado limitar o crescimento das concessionárias (VILARDAGA, 1999; HESSEL; VILARDAGA, 2000).

Outros aspectos relacionados ao surgimento de grandes revendas e que têm preocupado as montadoras são: eventuais problemas administrativos em grandes revendedores que possam prejudicar a imagem ou comprometer a participação de uma marca no mercado (ALMEIDA, 2000); e o surgimento de grandes revendas que comercializam várias marcas (FUSÕES...,2000) o que também, segundo acredita-se, prejudicaria a imagem das marcas e poderia trazer uma deteriorização dos serviços a elas vinculado, elemento importante de lealdade ao fabricante do veículo (URDAN; ZUÑIDA, 2001). Aspectos esses também identificados no cenário americano. 
Outra inovação na distribuição é a consolidação do comércio eletrônico de carros novos no Brasil. Segundo a EConsulting Corp., em 2003, o varejo online correspondeu a 2,75\% do varejo total do país, e o comércio eletrônico de carros respondeu por cerca de $62 \%$ do valor total das compras realizadas pela Internet (INDICE...,2004). Entende-se por varejo online o volume vendido pelo varejo a partir da Web, não necessariamente por meio de transação ou pagamento pela Internet. Esse é o caso principalmente das montadoras de veículos.

O comércio eletrônico de carros trouxe dois elementos novos na distribuição de veículos no Brasil: 1) um novo intermediário, os sites de veículos independentes; 2) as vendas diretas de carros novos através dos sites das próprias montadoras.

Os modelos de sites de veículos independentes são os mais variados. O que predomina no Brasil é o site de serviço de informação. Os maiores sites brasileiros são o Webmotors e o Carsales. O Webmotors não vende diretamente o veículo, apenas age como intermediador para os interessados em anunciar e comprar. Além disso, fornece informações sobre veículos e serviços automotivos. No Carsales pode-se configurar, comparar e comprar o veículo. O site opera um sistema muiltmarcas por meio de um pool de concessionárias autorizadas. Ele localiza o carro escolhido, oferece opções de compra, encomenda o carro se necessário, fornece o preço, realiza a transação e entrega do carro. Ferreira (2003) avalia que, no Brasil, a Internet ainda está sendo sub-utilizada pelo segmento automotivo. A expectativa é que nos próximos anos o segmento automotivo possa conquistar mais consumidores com acesso à Internet.

De maior impacto sobre a distribuição de veículos no Brasil, são os sites de comércio eletrônico das próprias montadoras. Por meio dele concretizaram-se as possibilidades de vendas diretas da montadora ao consumidor. É uma ação mais direta das montadoras sobre a distribuição, encurtando o canal e reduzindo a distância entre o produtor e o consumidor. A Ford foi a pioneira no Brasil a utilizar site de comércio eletrônico. Era possível, através dele, obter informações sobre veículos, financiamento e iniciar as negociações, porém não era possível efetuar a compra propriamente dita. Esta tinha que ser feita por uma concessionária (VILARDAGA,1999). Foi a GM que inaugurou a venda direta de veículos pela a Internet, com o Celta (SILVA, 2000). Por esse sistema, o carro é faturado diretamente da montadora para o consumidor, porém a intermediação da compra é feita pela concessionária bem como a 
entrega do veículo e as atividades de pós venda. Por essas atividades, as revendas recebem uma comissão (SILVA, 2000).

A Ford e a Fiat remodelaram seus sites para comercializar o Ford Fiesta, o Palio Young e o Mille. Em 2001, a Renault cria o seu site de comércio eletrônico para a venda do Clio Yahoo! pela Internet. Em 2002 a Volkswagen inicia as vendas pela Internet com o Pólo, e em 2003 foi a vez da Peugeot com o modelo 206.

No início, esse novo canal de distribuição levantou no país uma série de especulações sobre o futuro das concessionárias. Posições mais radicais chegaram a falar no fim das mesmas. Outra possibilidade aventada foi uma mudança do papel das revendas, com as vendas sendo realizadas diretamente pelas montadoras, caberia às revendas principalmente a entrega do carro, bem como os serviços de manutenção e reparo, a compra e venda de carros usados e outros serviços complementares, como seguros (ALMEIDA, 2000). Ou seja, as revendas assumiriam um papel secundário na venda de veículos (ARBIX; VEIGA, 2001). A venda direta ao consumidor final é proibida no Brasil, a não ser nas situações especificadas na lei, como é o caso de frotas. O lançamento do Celta gerou um conflito de canal. Os distribuidores de veículos, através da Fenabrave e das associações de marcas, reagiram e negociaram regras para a comercialização de veículos online. Para regular o conflito, foi estabelecida uma comissão para as concessionárias pela entrega e revisão inicial do carro, um recurso que tem se mostrado eficiente para administrar os conflitos na situação de introdução de canais diretos, especialmente o comércio eletrônico (TSAY; AGRAWAL, 2004). Outras estratégias também têm sido usadas pelas montadoras como a segmentação por produto e o direcionamento da demanda gerada pelo novo canal para o distribuidor.

Embora o novo canal não se configure mais na ameaça à existência da rede de revendedores a ele atribuído no início (ASSOCIAÇÕES..., 2002) há que se considerar os conflitos que surgirão com o canal tradicional. É inegável também que ele traz impactos no sentido de estabelecer uma nova divisão do trabalho dentro do canal de distribuição de automóveis novos no país, reorientando os revendedores para outras atividades (ALMEIDA, 2000), além de modificar as relações fabricantes-revendedores, fabricante-consumidores finais e revendedores-consumidores finais. Sobre esses últimos aspectos, estima-se que atualmente no Brasil, 20\% da população consumidora de veículos utilizam sites automotivos para dar suporte à decisão de compra de um automóvel (FERREIRA, 2003). 
Quanto às vendas propriamente ditas pela Internet, elas variam de montadora para montadora: na Fiat ela representam cerca de $14 \%$, enquanto na GM estão em torno de $40 \%$ e na Volkswagen em $18 \%$. No entanto, ressalta-se que boa parte dessas vendas são concluídas nas concessionárias. Fatores como o comportamento do consumidor são apontados para justificar essa situação: os sites de comércio eletrônico podem ajudar os consumidores a coletar informações sobre os modelos disponíveis, mas eles podem preferir continuar comprando seus carros nas concessionárias tradicionais, pois podem ver o carro desejado, fazer um testdrive etc. Outro aspecto considerado pelos consumidores diz respeito à segurança. $\mathrm{O}$ valor de um carro é alto e os consumidores podem não se sentir seguros em comprar um carro que não estão vendo (MORAES, 2000).

A situação atual da distribuição de carros novos no Brasil é de indefinição. O aumento da concorrência e das incertezas deve levar as montadoras e revendedores a um período de inovação e experimentação para, depois, se escolherem os formatos mais eficientes. $\mathrm{O}$ resultado pode até ser uma combinação de várias soluções, com uma nova divisão do trabalho dentro do canal como propõem Narus e Anderson, (1996) e Wise e Baumgartner (1999). 


\section{O MÉTODO E OS PROCEDIMENTOS DE PESQUISA}

Este capítulo trata do método de pesquisa utilizado neste trabalho. Inicialmente apresenta-se o tipo de estudo realizado, um survey, complementado com entrevistas, e discutem-se alguns elementos desse tipo de estudo. Apresentam-se os detalhes e particularidades do trabalho de campo, incluindo o levantamento preliminar de dados, a formulação das proposições, o delineamento do survey, a determinação da amostra de empresas estudadas e o instrumento de pesquisa usado. Levantam-se as vantagens do método empregado e finalmente, apontam-se algumas limitações do trabalho.

\subsection{O tipo de estudo}

O tipo de pesquisa a ser desenvolvido depende do quanto se sabe a respeito do problema a ser investigado. Quando relativamente pouco se sabe sobre o fenômeno a ser estudado, recomenda-se uma pesquisa do tipo exploratória. De outro lado, quando o problema está definido, estudos descritivos ou casuais são indicados (SELLTIZ, et al, 1974). No entanto, é preciso ressaltar que nem sempre é possível uma separação clara entre os dois tipos de estudo, uma vez que existe um campo de sobreposição entre eles. Há ainda estudos que podem conter elementos de duas ou mais categorias acima descritas.

É o caso desta pesquisa, que contém elementos de estudo exploratório e descritivo. É exploratório em função da reduzida quantidade de informações sobre o fenômeno a ser investigado; é descritivo porque se pretende também identificar a ocorrência de certos eventos e descrever sua distribuição em uma dada população, bem como fazer comparações entre essas distribuições.

Os dados para este trabalho foram levantados principalmente de um survey. No entanto, outras fontes de evidências foram utilizadas como entrevistas e análise de publicações sobre o assunto.

O survey foi escolhido devido ao fato de ser um método de pesquisa em ciências sociais adequado para estudos exploratórios e descritivos (OPPENHEIM, 2001; KIDDER; JUDD, 1986). É utilizado quando se deseja responder questões sobre a incidência, a distribuição e a 
relação entre determinadas características da maneira como elas ocorrem em uma população (Kidder e Judd, 1986), bem como para verificar se a percepção dos fatos está ou não de acordo com a realidade (PINSONNEAULT; KRAEMER, 1993 apud FREITAS et al., $2000)^{20}$. Nos surveys os dados são coletados em um ponto no tempo, com base em uma amostra para descrever a população nesse determinado momento. $\mathrm{O}$ fato dos informantes responderem às mesmas questões permite que a incidência e a distribuição de determinadas características populacionais sejam estudadas, e que relações entre elas sejam exploradas. É portanto adequado aos objetivos desta pesquisa de verificar as inovações em termos de práticas das gestão e uso de tecnologias de informação, bem como de identificar a existência de outros formatos de varejo de automóveis novos no Brasil e a ocorrência de mudanças no padrão de relacionamento entre montadora e rede de concessionárias.

\subsection{A formulação das proposições}

Pesquisas exploratórias não têm o objetivo de testar hipóteses, no entanto, Yin (1994) considera necessário o estabelecimento a priori de proposições, que orientem o pesquisador dentro do tema a ser pesquisado.

Considerando tal necessidade, iniciou-se este estudo com um levantamento bibliográfico prévio sobre canais de distribuição e distribuição de veículos. Além disso, acompanharam-se as notícias sobre a distribuição de veículos publicadas em jornais e revistas da área. Fez-se também uma análise dos conteúdos dos sites das associações de marcas, da Fenabrave e do NADA. Isso permitiu observar e acompanhar alguns "movimentos" do setor, como os assuntos em pauta, as propostas para o setor etc.

Alguns pontos colocados pela literatura sobre canais de distribuição e distribuição de veículos pareceram importantes para abordar a questão da distribuição de veículos no Brasil. São eles:

- Especialização. Aspecto importante no projeto de canais de distribuição, diz respeito ao nível de serviço oferecido pelo canal (STERN; EL-ANSARY; COUGHLAN, 1996; NARUS; ANDERSON, 1996). Os membros do canal tendem a organizar suas atividades funcionais de forma a minimizar os custos totais do canal no que diz respeito aos níveis de serviços desejados. O que significa que cada membro do canal tende a se especializar nas

\footnotetext{
20 PINSONNEAULT, A.; KRAEMER, K. L. Survey research in management information systems: an assessement. Journal fo Management Information System, 1993
} 
funções que desempenham de forma mais eficiente, delegando as demais a terceiros, e a se organizar de forma a reduzir os custos totais da distribuição. Um dos pontos centrais dos argumentos de Mercer (1994) e Chanaron e Jullien (1999) sobre a falência do sistema atual de distribuição é justamente a constatação de falta de escala no nível de cada revenda que justifique a integração de funções no mesmo local. Assim, uma melhoria do sistema passaria necessariamente por uma reestruturação do negócio da revenda através da desagregação e especialização de suas funções. No Brasil, a situação da rede é ruim; a rentabilidade do negócio é baixa e também se constata o problema de escala. Há consenso sobre a necessidade de buscar um novo formato de negócio, com compartilhamento de recursos e formação de parcerias (NOVOS..., 2001; ARBIX; VEIGA, 2001; ASSOCIAÇÕES...,2002);

- Tendência de buscar relacionamentos mais cooperativos entre os membros do canal. Segundo Kumar (1996), Fites (1996) e Narus e Anderson (1996), o uso do poder não tem garantido mais vantagens competitivas. Vantagens competitivas sustentáveis podem ser obtidas através de formas mais cooperativas de relacionamento entre produtores e distribuidores. Elas reduzem o nível de conflito no canal, melhoram a coordenação entre seus membros e permitem que novas oportunidades de negócios sejam exploradas (ANDERSON; WEITZ, 1992). Redução do número de distribuidores, garantia de exclusividade de área de atuação e uso de sistemas logísticos e de sistemas de informação compartilhados são fatores que tendem a tornar os relacionamentos cooperativos mais factíveis. Buzzavo e Volpato (2001) apontaram a tendência de redução do número de revendas na Europa e a intenção de algumas montadoras de estabelecer relacionamentos mais próximos com poucos intermediários. Também nos Estados Unidos discutia-se a necessidade de se buscar formas mais cooperativas de relacionamento entre rede de distribuição e montadoras.

- Tendências no varejo. Entre as principais estão: uso de intensivo de tecnologias da informação para controle de estoques, controle de custos, comercialização de produtos e serviços e ampliação do mix de serviços oferecidos aos clientes como forma de obter vantagem competitiva (KOTLER, 2002; CHURCHILL; PETER, 2000). Este último item já se configurou como uma tendência entre as revendas norte-americanas. No Brasil, discutia-se, no início dos anos 2000, essa possibilidade (CRIATIVIDADE...,2001).

- Venda direta. A introdução de um novo canal de vendas de carros novos no Brasil e os conflitos potenciais advindos dessa introdução. 
Após esse levantamento bibliográfico preliminar, iniciou-se um trabalho de campo com uma série de entrevistas de caráter exploratório com concessionários e representantes do setor para averiguar a pertinência dos aspectos descritos acima para o caso brasileiro. Os primeiros entrevistados foram: o coordenador econômico da Fenabrave, o coordenador econômico da Assobrav e o assistente de diretoria da Associação Brasileira dos Concessionários Renault (ABRARE). Essas duas associações foram as primeiras a serem contatadas nessa fase da pesquisa devido aos seguintes motivos: a Assobrav é a mais antiga das associações de marcas e seus membros tiveram papel importante na regulamentação do setor no país, além disso, pelo fato dela representar os concessionários de uma das mais antigas e maiores montadoras instaladas no país; a Abrare por representar os concessionários de uma das novas montadoras instaladas no Brasil, que naquela época era a que mais crescia em termos de mercado. Dos concessionários foram entrevistados o gerente de vendas da concessionária Fiat, que comercializa cerca de 70 carros novos/mês, o gerente de vendas de uma concessionária Peugeot, que vende 60 carros novos/mês e o proprietário de uma concessionária GM, que vende 70 carros/mês. Com isso, procurourse ter uma visão das questões em pauta nas diferentes redes de distribuição existentes no país. Para a realização dessas entrevistas foram elaborados dois roteiros com questões abertas para orientar a coleta de dados, um para as associações e outro para as concessionárias (Anexo 1). O contato inicial com os entrevistados foi feito por telefone. Em 3 casos o entrevistado solicitou o envio prévio das questões a serem abordadas, o que foi feito por e mail. No entanto, tomou-se o cuidado de encaminhar, juntamente com o roteiro, uma carta esclarecendo que as questões eram apenas uma referência e que durante a entrevista outras questões poderiam ser feitas. Foi também entrevistado um consultor técnico de uma montadora, mas essa entrevista não foi inicialmente programada. O contato foi feito durante uma entrevista com o gerente de vendas de uma concessionária e não houve um roteiro previamente elaborado. A entrevista iniciourse abordando os problemas da rede de distribuição na visão da montadora e evoluiu para outros temas como o comércio eletrônico de carros novos, a relação da rede com a montadora e as novas exigências das montadoras para com os concessionários. No total foram 7 entrevistas com duração média de 1 hora, realizadas entre dezembro de 2001 e abril de 2002. Em cinco casos houve permissão para que a entrevista fosse gravada; nos outros dois foram feitas anotações.

Alguns dos principais resultados obtidos foram: 
- Relacionamento montadora-rede de distribuição. É ainda marcado pelo conflito. Há pressão por volume, mas outros aspectos começam a ganhar importância como a qualidade de atendimento e serviço. Há diferenças entre as montadoras, mas observourse uma certa flexibilização no sistema de cotas, abrindo espaço para uma maior participação do concessionário na determinação do mix de produtos. Os pontos de maior atrito são a margem e a falta de novos produtos. Alguns elementos considerados novos, pelos entrevistados, no relacionamento com a montadora são o maior suporte em treinamento, não só em mecânica, mas também em vendas e maior suporte em gestão. Há neste ponto também diferenças entre as montadoras. Todos os entrevistados declararam que as montadoras então dando um maior retorno em relação às pesquisas de opinião sobre o atendimento. Identificou-se também que, com diferentes graus, as montadoras começavam a exigir certas padronizações, quanto ao ambiente da loja e processos de atendimento. Aspecto esse mais visível nas novas redes.

- Gestão da concessionária. As concessionárias são em sua maioria pequenas e médias empresas de gestão familiar. Observou-se a preocupação das associações em capacitar os revendedores em técnicas de gestão e uso de tecnologias de informação. No entanto, as associações relataram que havia muita resistência por parte dos revendedores. Além disso, discutia-se na época, nas associações, a estruturação de programas que auxiliassem as concessionárias a melhorar a rentabilidade explorando de forma mais adequada outras atividades como oficina e venda de carros usados e incorporação de novos serviços. Havia uma experiência de uma concessionária que estava sendo acompanhada pela associação de marca. Ela estava fazendo contatos formais de parcerias com prestadores de serviços automotivos para terceirizar algumas atividades como funilaria e pintura, serviços rápidos e de geometria dos carros e injeção eletrônica para operar a oficina dentro da concessionária. Em duas concessionárias o processo de informatização era incipiente; na última, o processo estava bem avançado e eles começavam a operar o sistema de comércio eletrônico e estavam comprando um software de CRM. As três estavam em fase de estudo para a implantação de programa de qualidade. Uma concessionária estava desativando a funilaria e terceirizando completamente a atividade. Outra já tinha terceirizado a parte de geometria do carro e estava estudando a possibilidade de terceirizar os serviços de funilaria.

Considerando as entrevistas realizadas, que apresentam evidências de mudanças na gestão das revendas e no relacionamento entre montadora e concessionárias, e os pontos levantados na 
literatura foi possível formular as seguintes proposições que orientaram o trabalho empírico na fase seguinte da pesquisa.

P1: As concessionárias de automóveis novos no Brasil estão se reestruturando, buscando terceirizar algumas de suas funções ou compartilhar recursos a fim de recuperarem suas margens e rentabilidade.

P2: Está havendo uma mudança no padrão de elacionamento entre montadora e rede de distribuição no sentido de construir relacionamentos mais cooperativos.

P3: As concessionárias de automóveis novos no Brasil estão inovando através da adoção de novas práticas de gestão, da utilização das tecnologias da informação e ampliação dos serviços oferecidos aos clientes.

\subsection{O método de coleta de dados}

As entrevistas iniciais permitiram delimitar algumas questões a serem respondidas e definir as variáveis a serem medidas, possibilitando uma abordagem mais padronizada sobre o tema. Inicioutse então o delineamento de um survey que foi realizado junto às redes de concessionárias com o objetivo de levantar dados para a análise das mudanças que estão ocorrendo na distribuição de veículos no Brasil, bem como levantar o perfil da rede em relação ao formato do negócio, uso das tecnologias da informação e adoção de novas práticas de gestão.

Os dados foram coletados através de questionário estruturado enviado por e mail a 523 concessionárias dos estados de São Paulo, Rio de Janeiro e Paraná durante os meses de maio e junho de 2004. O retorno foi de 41 questionários (7,8\%). O uso de questionário estruturado apresenta diversas vantagens que foram particularmente relevantes para a consecução dessa pesquisa, pois permite: obter informações de um grande número de pessoas em um tempo relativamente curto; quantificar melhor as informações; tabular os dados com maior facilidade e rapidez que outros instrumentos, como por exemplo, a entrevista (SELLTIZ et al., 1974; KIDDER; JUDD, 1986). 
Decidiu-se pela realização do survey por e-mail devido a algumas vantagens apresentadas sobre os realizados pelo correio, tais como: menor custo, melhor taxa de retorno, melhor controle da amostra, menor quantidade de itens não respondidos, maior rapidez na aplicação, menor tempo de resposta, melhor controle sobre os não-respondentes (SIMSEK, 1999). Em geral, o grande problema do survey por e-mail é o não conhecimento da população a ser pesquisada, o que pode comprometer a extensão das conclusões para a população (problema de validade externa). Porém, no caso particular desta pesquisa, a população é conhecida. Os endereços eletrônicos das concessionárias foram obtidos principalmente através das associações de marcas. Nos casos em que a solicitação dos endereços eletrônicos foi negada, estes foram obtidos através dos sites das montadoras.

Um dos maiores problemas das pesquisas do tipo survey são as baixas taxas de retorno dos questionários. Quando uma população é pesquisada, as conclusões são referentes a essa população, assim, quando as taxas de retorno são muito baixas, deve-se fazer ressalvas nas conclusões, já que a parte correspondente aos que não responderam pode mudar os resultados (RICHARDSON, et. al, 1985; KIDDER; JUDD, 1986). Para aumentar a taxa de retorno, algumas ações foram executadas. Primeiro, encaminhou-se junto com o questionário uma carta explicando os objetivos da pesquisa, garantindo o sigilo das informações recebidas e assumindo um compromisso de retorno aos respondentes sobre os resultados obtidos (Anexo2). Segundo, os questionários foram endereçados aos proprietários e gerentes de vendas dos concessionários, pois segundo levantourse na fase inicial da pesquisa, eles têm as informações que se deseja saber. Terceiro, fez-se um acompanhamento da devolução dos questionários: após 15 dias da data de envio, um novo e mail contendo o questionário anexado foi enviado para as concessionárias solicitando o seu retorno.

Em alguns casos, após o recebimento do questionário, foram feitos contatos telefônicos com os respondentes para esclarecer dúvidas sobre o preenchimento.

Os dados dos questionários foram tratados através de técnicas de estatística descritiva, tais como gráficos, distribuição de freqüências e medidas associadas a essas distribuições, como médias, medianas, amplitude e desvio padrão. A apuração dos dados foi feita através do software Estatística. Os resultados obtidos estão no capítulo 4 desta tese. 
Uma dificuldade do uso do questionário é que as respostas ficam limitadas ao conteúdo do instrumento. Assim, após a realização do survey, foram feitas mais 4 entrevistas: uma com o diretor da Associação Brasileira dos Distribuidores Toyota (ABRADIT), outra com o proprietário de uma concessionária Peugeot de São Paulo, que comercializa cerca de 25 carros novos por/mês, outra com o gerente de vendas de uma concessionária Volkswagen do Paraná, que vende cerca de 150 carros novos por/mês (entrevista feita por telefone) e a última com o gerente de vendas de uma concessionária Toyota de São Paulo, que vende em média 30 carros/mês. O roteiro básico dessas entrevistas foi o próprio questionário. Com isso, pode-se aprofundar a compreensão e certos aspectos, especialmente no que diz respeito ao processo de terceirização de algumas atividades da revenda e da relação dos distribuidores com as montadoras.

\subsubsection{A amostra das empresas}

Foram selecionadas para fazer parte dessa pesquisa as concessionárias que representam as marcas Fiat, Ford, GM, Volkwagen, Peugeot, Renault e Toyota, dos Estados de São Paulo, Rio de Janeiro e Paraná. A tabela 3.1 abaixo apresenta a participação de cada uma das marcas nesse mercado.

Tabela 3.1 - Participação da marcas nos Estados de São Paulo, Rio de Janeiro e Paraná em maio de 2004.

Fiat

Ford

Toyota 
Nesses Estados, segundo dados da Fenabrave, são comercializados cerca de 51,5\% dos carros novos vendidos no país e estão concentradas 1/3 das concessionárias de automóveis do Brasil. Estão também localizadas nesses Estados as maiores revendedoras de automóveis novos do país. A tabela 3.2 abaixo apresenta a distribuição das 523 concessionárias por marca e por Estado. Trata-se portanto de uma amostra intencionalmente constituída, que pelas suas características deve ser representativa do que está ocorrendo no país.

Tabela 3.2 - Distribuição do número de concessionárias por Estado em unidades.

Marcas

\section{$\overline{\mathrm{GM}}$} 17

Fiat 15

Volkswagen 26

Ford 24

Renault 7

Toyota 5

Peugeot 6

O gráfico 3.1 abaixo apresenta a distribuição das 523 concessionárias por estado.

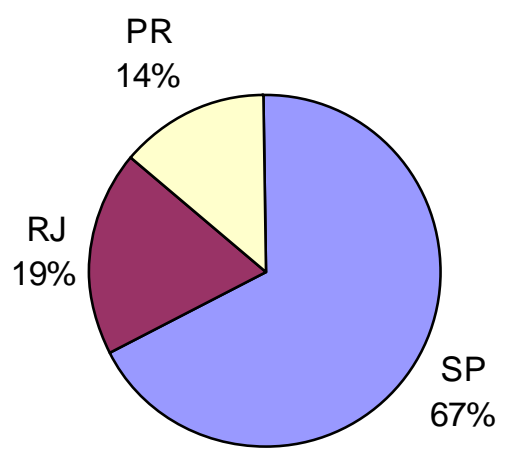

Gráfico 3.1 - Distribuição dos concessionários por Estado. 


\subsection{2 $\mathrm{O}$ instrumento de pesquisa}

O desenvolvimento do questionário ocorreu da seguinte forma: uma primeira versão foi elaborada e realizou-se, entre fevereiro e março de 2002, o primeiro pré-teste, que foi realizado da seguinte maneira: o questionário foi entregue ou para o gerente de vendas ou para o proprietário de 6 concessionárias de 6 marcas especificadas anteriormente. Para cada um, foram explicados os propósitos da pesquisa e foi solicitado que respondessem às questões sozinhos, como se tivessem recebido o questionário pelo correio. Depois de alguns dias, entrou-se em contato para obter o retorno do questionário e foi solicitada uma entrevista para que eles comentassem as questões e esclarecessem suas dúvidas. Dos 6, 3 responderam o questionário e concederam entrevistas para discutir as questões. Assim foi possível saber como eles entenderam as questões e suas dúvidas sobre os termos usados, o que possibilitou uma primeira avaliação e revisão do instrumento de pesquisa.

Com base nessas entrevistas, na análise das respostas e na continuação da revisão bibliográfica sobre o assunto, o questionário foi revisto e questões sobre a relação com as montadoras foram incluídas. Identificou-se também que as pessoas mais adequadas para responderem o questionário são os gerentes de vendas ou os proprietários das concessionárias. Um outro pré-teste foi realizado, dessa vez com 4 concessionárias de marcas diferentes. Somente dois questionários retornaram e os respondentes concederam entrevista por telefone. Com base nos comentários dos respondentes, o questionário foi novamente revisto e foi elabora a versão final (Anexo 2).

A realização desses pré-testes é uma fase importante e indispensável da pesquisa, pois ela tem o objetivo de reduzir os problemas de validade interna, que é uma das maiores críticas aos surveys realizados através de questionário, isto é, que existe a possibilidade das informações fornecidas pelos respondentes não corresponderem à realidade (KIDDER; JUDD, 1986). Ao contrário do que ocorre na situação de entrevista, onde o pesquisador pode, se recessário, discutir com o entrevistado a coerência de suas respostas, a natureza impessoal da relação entre pesquisador-informante, que caracteriza o questionário, dificulta a verificação da validade das descrições. Pode ocorrer também das pessoas atribuírem às perguntas sentido diferente daquele atribuído pelo pesquisador. (RICHARDSON, et al, 1985; KIDDER; JUDD, 
1986). Assim, a realização de testes antes da aplicação efetiva dos questionários deve reduzir o viés na apresentação das questões.

\subsubsection{O Questionário}

Com relação ao seu conteúdo, o questionário atual está dividido em 5 blocos: perfil das revendas, estrutura da concessionária, relação concessionária-montadora, inovações na revenda e sobre o negócio.

No Bloco 1 "Perfil das Revendas" são coletados dados sobre tamanho, volume de vendas e composição das revendas.

No Bloco 2 "Estrutura da Concessionária " procura-se identificar o formato da revenda e a terceirização de algumas de suas atividades ou funções, ou seja, venda de carros usados, serviços de funilaria, serviços de oficina mecânica e serviços rápidos. As questões deste bloco referem-se à proposição P1.

No Bloco3 "Relação Concessionária - Montadora” busca-se identificar como está a relação entre montadora e concessionária. As questões referem-se à proposição P2 e abordam os fatores que pesam nas negociações com as montadoras, como são negociadas as promoções, os tipos de suporte dados pelas montadoras, a estrutura de comunicação e as exigências das montadoras.

No Bloco 4 "Inovações m Revenda" busca-se ter uma visão do uso das TI e da adoção de novas práticas de gestão e da oferta de serviços. As questões referem-se à proposição P3. Os dados a serem levantados são sobre o uso das tecnologias da informação, a adoção de novas práticas de gestão, como programas de qualidade e programas de fidelização do cliente, além de levantar os tipos de serviços que estão sendo oferecidos.

No bloco 5 "Sobre o Negócio" procura-se levantar dados sobre a participação de cada atividade no lucro, os concorrentes e a estratégia da rede. 


\subsection{Análise dos Resultados}

As análises foram feitas com base nos dados obtidos pelos questionários e pelas entrevistas (aquelas realizadas durante a fase de coleta preliminar dos dados, e após o envio do questionário) e também pelas entrevistas realizadas durante a fase de pré-teste do questionário, dado que elas não ficaram restritas ao conteúdo do questionário e foram importantes para a compreensão da situação das revendas e da rede de distribuição como um todo.

O quadro 3.1 abaixo apresenta um resumo das entrevista realizadas e dos instrumentos de pesquisa utilizados desde a coleta inicial de dados para a formulação das proposições até as entrevistas realizadas após o envio do questionário.

Coleta inicial

\section{Fase da Pesquisa $\quad$ Instrumento}

- 1 entrevista Fenabrave Roteiro com questões abertas (Anexo 1)

- 2 entrevistas Ass. de Marcas Roteiro com questões abertas (Anexo 1)

- 3 entrevistas em concessionárias Roteiro com questões abertas (Anexo1)

Fase de Pré-teste do questionário

- 5 entrevistas em concessionários Entrevista diretiva

Fase pós-questionário

- 1 entrevista Ass. de Marcas Roteiro com questões abertas

- 3 entrevistas concessionárias Entrevistas diretivas

Quadro 3.1 - Resumo das entrevistas realizadas

\subsection{Limitações do estudo}

As maiores críticas aos survey realizados através de questionário são relativas à validade interna (KIDDER e JUDD, 1986), ou seja, existe a possibilidade de que as informações fornecidas pelos respondentes não correspondam à realidade. Ao contrário do que ocorre na situação de entrevista, onde o pesquisador pode, se necessário, discutir com o entrevistado a coerência de suas respostas, a natureza impessoal da relação entre pesquisador-informante que caracteriza o questionário dificulta a verificação da validade das descrições (SELLTIZ, et al, 1974). Pode ocorrer também das pessoas atribuírem às perguntas sentido diferente daquele atribuído pelo pesquisador. Acredita-se, contudo, que a realização de testes antes da aplicação efetiva dos questionários tenha reduzido o viés na apresentação das questões. 
Outra crítica diz respeito ao grau de profundidade com o qual um tema é tratado. Embora o emprego de questionários fechados permita uma melhor quantificação das informações, estas ficam limitadas ao conteúdo do instrumento. Assim, sentimentos ou interpretações dos respondentes a respeito dos fatos não podem ser explorados. Dessa forma, esses estudos não permitem que um fenômeno (individual, organizacional, social ou político) seja explorado com profundidade, como ocorre nos estudos de caso, onde uma situação particular é estudada procurando-se compreender como e porquê determinados fatos ocorreram e quais os significados a eles atribuídos (KIDDER e JUDD, 1986). Assim, no caso específico dessa pesquisa, aspectos como: os processos que levaram as concessionárias a tomarem certas ações; o impacto no negócio como um todo; a forma como certas iniciativas estão ocorrendo, como adoção de novas práticas de gestão e introdução de tecnologias de informação; e as dificuldades enfrentadas, não puderam ser elucidadas através desses estudos. Porém, essa falta de profundidade pode ser compensada pelo maior grau de generalização dos resultados.

Finalmente, existe a questão da representatividade da amostra. $\mathrm{O}$ processo de seleção da amostra afeta o grau com que os dados podem ser generalizados para a população. A seleção de empresas utilizadas neste trabalho não se caracteriza como uma amostra probabilística, que corresponde ao único tipo de abordagem que possibilita planos de amostragem representativos. Portanto, esse trabalho não permite que os resultados obtidos sejam estatisticamente generalizados para a população de concessionárias do país, e nem é essa a proposição geral. Assim, devem ser tomados os devidos cuidados na passagem particulargeral. Contudo, o método empregado e as características do levantamento permitem que sejam sugeridas inúmeras análises e conclusões a respeito do tema em estudo, como será visto no decorrer do trabalho. 


\section{ANÁLISE DA PESQUISA DE CAMPO}

Este capítulo apresenta os resultados da pesquisa de campo e está dividido em duas partes. $\mathrm{Na}$ primeira, com base nos dados coletados através de entrevistas com as associações de marcas e revendedores são apresentadas as descrições de 3 redes de distribuição de carros novos no Brasil. Na segunda são apresentados os resultados obtidos através do questionário enviado aos revendedores.

\subsection{Descrição das redes de distribuição}

Como dito anteriormente, as montadoras instaladas no Brasil disponibilizam seus produtos através de dois canais distintos: as redes de concessionárias e os sites de comércio eletrônico das montadoras. Há, no entanto, diferenças de funcionamento entre as redes quanto às formas de vendas no atacado, atribuição de cotas, peças de reposição e exigências quanto à padronização de aspectos como ambiente da loja, atendimento etc., como se apresenta a seguir.Essas descrições foram baseadas nas entrevistas com associações de marcas, concessionárias e na análise de documentos.

\section{a) Rede 1}

A rede se consolidou no Brasil na década de 1960 e já chegou a ter cerca de 800 pontos de vendas no país. No entanto, ela vem passando por um processo de enxugamento que se acelerou a partir do início dos anos 2000. Atualmente são cerca de 400 pontos de ve ndas entre matrizes, filiais e postos de assistência técnica. Estes últimos se constituem de pequenos showrooms com boxes para serviços rápidos de oficinas e venda de peças ligados a uma concessionária. Os postos de assistência técnica começaram a ser implantados no início dos anos 2000.

A relação com a montadora é regida por contrato de concessão renovado automaticamente a cada 2 anos. O contrato dispõe sobre a exploração de atividades de vendas de carros novos, vendas de carros usados, serviços de assistência técnica e peças de reposição. No mesmo showroom pode ser comercializada outra marca da montadora. 
A concessionária é periodicamente avaliada sobre saúde financeira. Aspectos como padronização da loja e processo de atendimento são secundários. Eles são recomendados, mas não há uma forte exigência da montadora ${ }^{21}$. Quanto aos treinamentos, eles estão restritos às técnicas de vendas, apresentação de novos produtos, e mecânicos. Há os que são gratuitos e outros que devem ser adquiridos pelas concessionárias.

Existe um sistema de troca de dados com a montadora, via satélite, através do qual são feitos pedidos de peças e veículos, programações de entregas, etc. O sistema teve ser adquirido pelo revendedor e existe uma taxa de manutenção mensal.

Há grande nível de conflito horizontal na rede devido principalmente às políticas agressivas de preço dos revendedores e às inovações de áreas. No entanto, a montadora está implantando uma política para garantir exclusividade territorial ao revendedor.

A montadora trabalha com um sistema de atribuição de cotas. As cotas são determinadas pela montadora em função do potencial de mercado de cada revendedor. O volume é fixo, porém, dependendo do tamanho do concessionário ele pode determinar o mix de produtos: concessionários que comercializam acima de 100 carros novos por mês têm opção de escolha de modelos, cor, opcionais e motorização. Já as revendas que comercializam menos de 100 unidades/mês têm apenas opção de cor, opcionais e motorização. Os volumes podem ser ajustados mensalmente pela montadora dependendo das condições de mercado, mas há um período de 3 meses no ano em que ele é fixo. Os concessionários fazem pedidos de veículos semanalmente para a montadora. Quanto à peças de reposição, as concessionárias são obrigadas a retirar mensalmente um volume mínimo estipulado pela montadora.

No atacado, a compra é feita à vista ou através de financiamento de floor plan, que não necessariamente precisa ser com o banco da montadora ${ }^{22}$. A concessionária tem normalmente prazo de 30 ou 60 dias, dependendo do modelo, para vender o carro. Ao final desse prazo, caso o carro não seja vendido, ele é faturado automaticamente para o concessionário para fins de revenda e a cota do revendedor é liberada.

\footnotetext{
${ }^{21}$ No entanto, sabe-se que está sendo formulada pela montadora uma política específica para isso.

${ }^{22}$ Esta sendo implantada atualmente a modalidade de vendas a prazo.
} 
A montadora também vende diretamente ao consumidor final através Internet. As vendas iniciadas pelo site são redirecionadas para a rede. Pelos serviços de revisão inicial e entrega, o concessionário recebe uma comissão. O comércio eletrônico é responsável por $18 \%$ do volume de vendas da montadora.

\section{b) Rede 2}

Até 1992, a montadora comercializava um único produto através da rede de uma outra marca. Com a abertura do mercado no início dos anos 1990, a montadora passou a trazer outros produtos de fora. Começou então um processo de reestruturação da rede de distribuição que terminou em 1997 com a formação de uma rede exclusiva da montadora. O processo iniciou com a ela verificando entre os antigos distribuidores quais se interessavam em representá-la. A exigência era uma concessionária exclusiva para a marca. Aqueles que não concordaram tiveram que ceder a concessão. Atualmente são 88 revendedores espalhados pelo país com aproximadamente 95 pontos de vendas. A montadora tem uma estratégia de expansão gradual da rede, procurando manter um número reduzido de revendedores e aumentando o número de filiais e implementando pontos de vendas mais enxutos - os open point-, pontos de vendas com pequeno showroom e serviços rápidos de oficina ${ }^{23}$. A idéia é evitar a duplicação desnecessária de ferramental e equipamentos de oficinas. A montadora monitora a ação do revendedor quanto às vendas fora da área de atuação no sentido de orientar os revendedores para que trabalhem para respeitar às áreas de atuação.

A relação com a montadora é regida por contratos de concessão com prazo indeterminado. $\mathrm{O}$ contrato dispõe sobre a exploração de atividades de vendas de carros novos, vendas de carros usados, serviços de assistência técnica e peças de reposição. É exigida exclusividade de marca.

A concessionária tem um padrão definido em termos de estética (tamanho mínimo, cores, disposição dos veículos, etc), processo de atendimento e pós-venda. A oficina também tem padrão de atendimento definido e tem que seguir a política de qualidade da montadora que determina o cumprimento do padrão 3S. No setor de peças de reposição existe até a recomendação sobre o posicionamento do ítem no estoque e das informações que elas devem

\footnotetext{
${ }^{23}$ Esse tipo de ponto de venda ainda está sendo formatado pela montadora.
} 
conter. Esses quesitos são avaliados periodicamente por consultores das áreas comercial e de pós-venda da montadora. A revenda é também avaliada periodicamente em termos de saúde financeira. Existe um sistema que pontua a revenda, e os quesitos de pós-venda têm grande peso na avaliação. Um dos reflexos diretos disso diz respeito à remuneração dos serviços de garantia: a montadora remunera os distribuidores nos serviços de garantia por valores variáveis de acordo com a pontuação da revenda. Outras recompensas são prêmios como viagens e diplomas. Para os quesitos considerados fora do padrão, são feitas recomendações pelos próprios consultores que atuam como conselheiros. Há forte ênfase em treinamentos que são oferecidos continuamente e gratuitamente pela fábrica. A montadora realiza onda de pesquisas de opinião sobre a qualidade do atendimento do revendedor junto ao consumidor final.

As revendas têm conexão on-line, via Internet, com a montadora. Através do sistema, são feitos pedidos de veículos e peças, programações de entregas, informes da montadora para rede, etc.

A montadora trabalha com um sistema de cotas, que são determinadas em função da capacidade de absorção de cada produto nas diferentes regiões do país, determinadas com base em pesquisas de mercado realizadas semestralmente pela montadora. O sistema tem certa flexibilidade e permite ajustes mensais de volume, mix de produtos e cor em função das condições de mercado. Há uma política de trabalhar com estoques reduzidos de carros e de peças de reposição na revenda. Quanto à reposição de peças, a rede trabalha com just-in-time. Há sistema logístico para entregas diárias de peças. Qualquer pedido de peças fora da média histórica da revenda tem que ser negociado com a montadora.

No atacado, a compra é feita à vista ou através de financiamento de floor plan, que não necessariamente precisa ser com o banco da montadora. A concessionária tem normalmente prazo de 30 dias para vender o carro. Ao final desse prazo, caso o carro não seja vendido, ele é faturado automaticamente para o concessionário para fins de revenda e a cota do revendedor é liberada.

Os consultores são o canal de comunicação entre o revendedor e a montadora, levando reivindicações dos revendedores para a montadora. Outro canal é a associação da marca que trata de assuntos gerais da rede como margem, promoções etc. 
Lançamentos de produtos e campanhas promocionais nacionais costumam ser apresentadas à rede com antecedência e os revendedores têm alguma influência sobre esta última.

Até o momento a montadora não vende diretamente para o consumidor final a não ser nos casos previstos por lei.

\section{c) Rede 3}

A montadora comercializa carros novos no Brasil através de dois canais de distribuição: de sua rede de concessionárias e diretamente através do seu site de comércio eletrônico.

A rede no Brasil começou a ser constituída no início da década de 90 . Atualmente são 89 matrizes com mais de 110 pontos de vendas. A montadora tem como estratégia manter um número reduzido de revendedores e aumentar o número de pontos de vendas através de filiais e de showroom.

A relação com os revendedores é regida por contratos de concessão com renovação automática. Os objetivos de vendas e a área de atuação da revenda são definidos pela montadora. É exigido exclusividade de marca e as concessionárias são obrigadas a seguir uma série de determinações:

- o standard da marca: define o padrão de loja como as cores das paredes, o lay-out, a colocação de banners, a identificação dos carros, condições de comercialização, identificação dos funcionários, uniformes, documentação, número de carros, test-drive, etc. Uma vez por mês as revendas são avaliadas pelo gerente regional de comercialização. A avaliação é feita por um sistema de pontuação. Dependendo da pontuação, a revenda recebe prêmios ou e penalizada. Entre os prêmios, estão valores em dinheiro sobre cada carro vendido para propaganda regional. Entre as penalidades estão o corte de verbas para propaganda e a indisponibilidade de produtos.

- padrão de pós-venda: diz respeito à recomendação do fabricante sobre os serviços de manutenção. A revenda é avaliada periodicamente pelo gerente regional de pós-venda. Existe também uma pontuação e recomendações como necessidade de reciclagem de mecânicos. Há premiações em dinheiro e outros tipos de prêmios como viagens. As sanções podem chegar ao rompimento do contrato de concessão. 
- políticas específicas como o preço fixo de peças de reposição; o custo fixo de revisão; a transparência com o consumidor na descrição dos serviços.

As metas de vendas de carros novos, serviços, peças e assessórios de cada revendedor são definidas no Plano Anual de Negócios, em função da participação no mercado. Esse plano é realizado com os revendedores, o gerente regional e o diretor comercial e de marketing da montadora. Há uma forte atuação do gerente regional no acompanhamento do cumprimento das metas. Para isso, as revendas contam com uma assessoria gratuita da montadora. Há forte ênfase em treinamentos que são gratuitos e abrangem áreas de gestão. A montadora monitora a atuação dos revendedores quanto às vendas fora de área no sentido de orientar-los para que respeitem as áreas de atuação.

No atacado, os carros são entregues para as revendas em consignação pelo prazo de 90 dias. Após esse prazo, se o carro não for vendido é faturado automaticamente para a concessionária. Tem-se a opção de compra à vista e atualmente está sendo implantada a compra através de financiamento de floor plan.

A montadora exige que o concessionário tenha uma certa porcentagem dos carros que ela vai comercializar em peças de reposição. É especificado no contrato o pacote de peças de uso contínuo que o revendedor deve ter. Partes de lataria, por exemplo, são consideradas demandas especiais e não precisam ser mantidas no estoque da concessionária. São solicitadas à fábrica quando necessário.

Há possibilidade, prevista em contrato, de terceirizar serviços. A objeção é feita para a oficina mecânica que só pode atender aos carros da marca.

A relação com a montadora se dá através de seu escritório comercial regional que tem departamento de garantia, de peças, pedidos em carteira e financeiro. Os contatos são feitos seguindo uma hierarquia, e qualquer contato feito fora dela não é bem recebido.

Nas promoções, os custos são divididos entre rede e montadora na proporção de $1 / 3$ para a rede e o restante para a montadora. Às vezes, há redução conjunta de margens. 
Nas vendas pela Internet, os carros são faturados diretamente para o consumidor. É feita à vista ou financiada e a entrega do carro ocorre em até 15 dias. A oferta de produtos é restrita aos carros mais populares. A participação do concessionário no processo é grande. O pedido do carro é feito pelo consumidor diretamente no site que emite uma intenção de compra. Com esse documento, o consumidor deve ir até uma concessionária, onde consultor de venda confere os dados, oficializa o pagamento da entrada e dá prosseguimento ao processo de compra.

\subsection{Resultados dos questionários}

Foram enviados 523 questionários para concessionários da rede Fiat, Ford, GM, Volkswagen, Renault, Peugeot e Toyota dos estados de São Paulo, Rio de Janeiro e Paraná. O retorno foi de 41 questionários, dando uma taxa de retorno de 7,8\%. Os respondentes foram: 18\% diretores, $28 \%$ titulares, $48 \%$ gerentes de vendas ou comerciais e $2 \%$ não se identificaram.

A seguir serão apresentados os resultados divididos em quatro blocos: o perfil das revendas que responderam ao questionário, o formato do negócio, a relação montadora-distribuidor, a inovação nas revendas, sobre o negócio.

\subsubsection{Perfil das revendas}

A maior parte das 41 revendas que responderam ao questionário é do estado de São Paulo (43\%). Em segundo lugar está o Paraná com 31\% e por último o Rio de Janeiro (26\%) conforme está mostrado no gráfico 4.1 . 


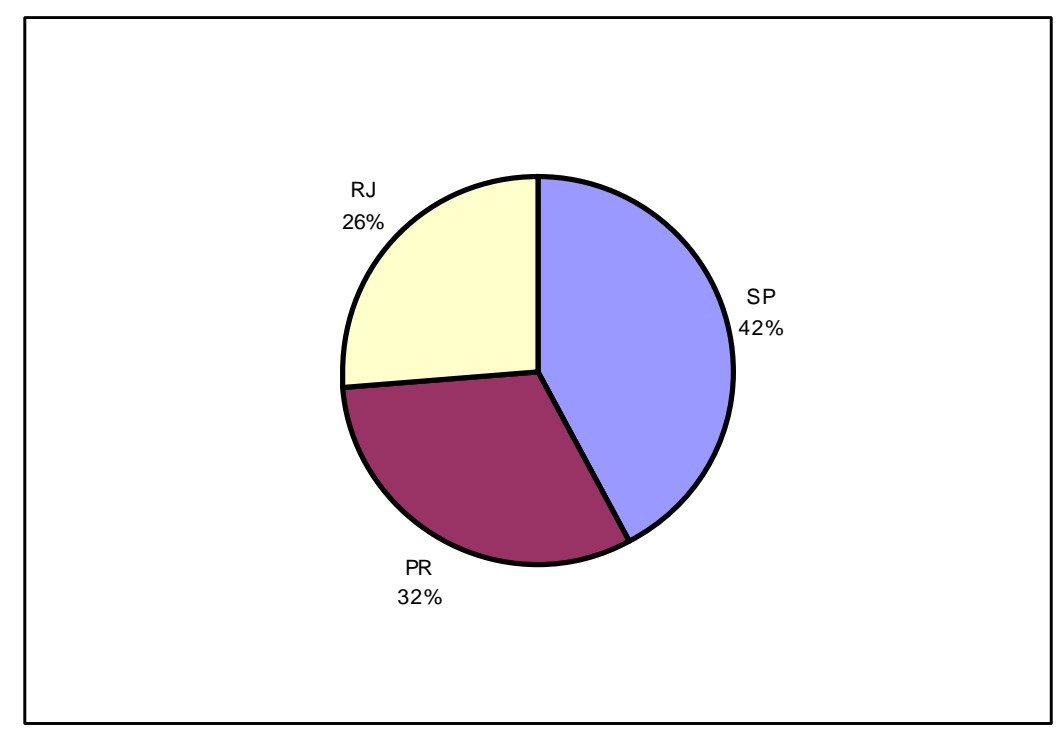

Gráfico 4.1 - Distribuição das revendas por estado.

Com relação às marcas, Volkswagen, Ford e Fiat tiveram a maior frequiência entre os respondentes e a Renault a menor (tabela 4.1).

Tabela 4.1 - Distribuição das concessionárias por marca.

\begin{tabular}{lc} 
Marcas & $(\%)$ \\
\hline Volkswagen & 33 \\
Ford & 26 \\
Fiat & 18 \\
GM & 5 \\
Toyota & 10 \\
Peugeot & 5 \\
Renault & 3 \\
\hline
\end{tabular}

Das 41 revendas, $89 \%$ são matrizes, sendo que 24\% delas possuem filiais. Em 29\% dos casos as revendas são controladas por um grupo econômico. Em 50\% desses casos, o grupo econômico controla revendas de outras marcas. Setenta e um por cento (71\%) possuem outros negócios relacionados com veículos, conforme mostra a tabela 4.2. 
Tabela 4.2 - Negócios associados.

Negócios associados

Garagem de usados

Locadora de veículos

Posto de gasolina

Peças e serviços

Outros

\section{(\%)}

40

31

5

3

8

Em média ${ }^{24}$, as revendas comercializam 40 carros/mês. Estima-se que, no Brasil, um volume razoável economicamente seria de 65 a 70 carros novos por mês (VILARGADA, 1999). Portanto, a maioria das revendas investigadas está abaixo desse valor (tabela 4.3). O perfil da amostra quanto ao número de carros novos vendidos por mês difere do perfil nacional apresentado no item 2.2.4. Há, na amostra, uma predominância de concessionárias médias e média grande.

Tabela 4.3 - Volume de carros novos comercializados por mês.

Vol. de vendas mensal (um)

Até 20 unidades

21 a 50 unidades

51 a 100 unidades

101 a 400 unidades 8

O número médio ${ }^{25}$ de atendimento na oficina é de 350/mês. A distribuição dos números de atendimentos encontra-se na tabela 4.4

\footnotetext{
${ }^{24}$ Como medida de centro da distribuição de freqüências utilizou-se a mediana ao invés da média, pois ela sofre menos a influência de valores extremos.

${ }^{25}$ Como medida de centro de distribuição utilizou-se também a mediana
} 
Tabela 4.4 - Número de atendimento na oficina por mês.

Número de atendimento na oficina $(\%)$

Até 200 22

$200-400$

$400-600$

$600-800$

8

$800-1000$

A maioria das revendas da amostra são pequenas e médias empresas. O número médio de funcionários é de 40. A distribuição referente ao número de funcionários está na tabela 4.5.

Tabela 4.5 - Porte das revenda quanto ao número de funcionários.

Número de funcionários

$10-49$

$50-99$

Acima 100
$(\%)$

59

31

10

A produtividade média (volume de vendas de carros novos por mês/número de funcionários) é de 1,0 , sendo que o valor mínimo é de 0,4 e o máximo de 2,3. Para $p<0,10$ não há evidência estatística de correlação entre o tamanho da revenda e a produtividade. No entanto, uma análise mais qualitativa do gráfico 4.2 sugere, no caso desta amostra de revendas, uma tendência das empresas maiores terem uma produtividade menor. 


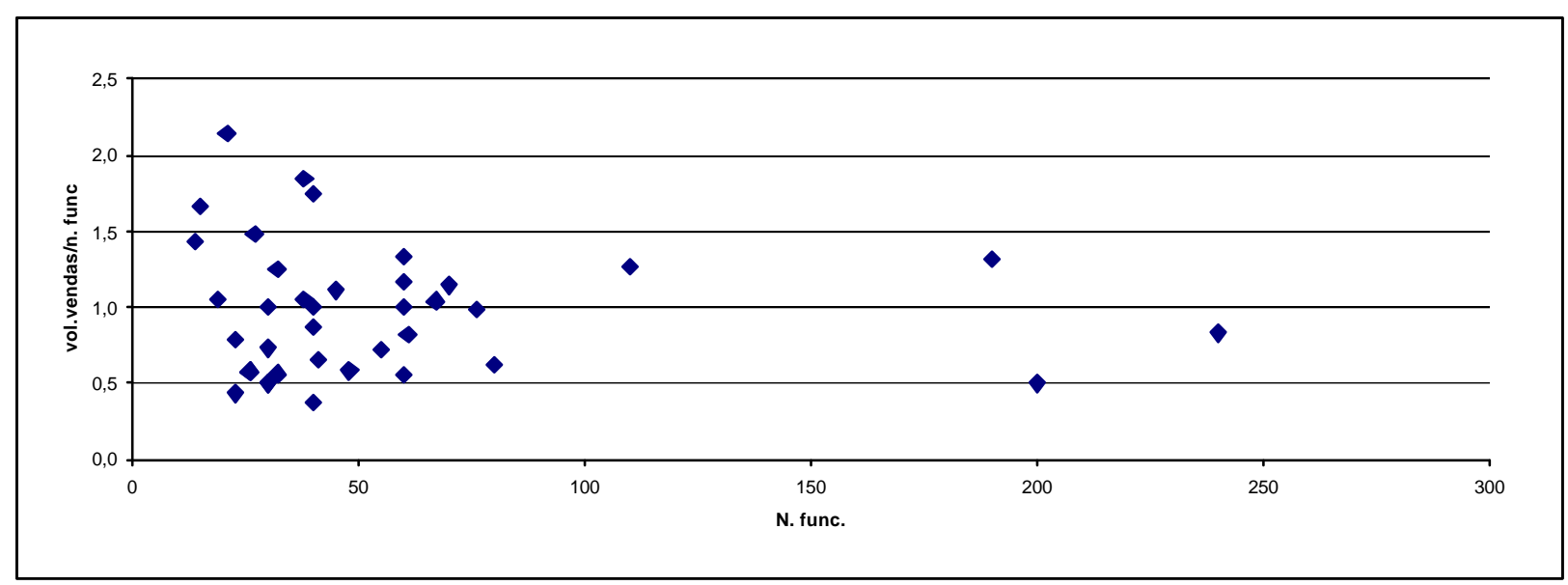

Gráfico 4.2 - Produtividade em função do tamanho da revenda.

No que diz respeito ao percentual de cada função da revenda na formação do lucro, há uma dispersão muito grande nos valores apresentados. Por exemplo, considerando a participação da venda de carros novos na formação do lucro, obteve-se respostas que vão de $10 \%$ a $70 \%$. O mesmo se verificou nos demais ítens. Tem-se todavia, que as revendas são bastante dependentes da venda de carros novos, ou seja, na média, cerca de $45 \%$ do lucro vem da venda de carros novos (tabela 4.6).

Tabela 4.6 - Origem do lucro das revendas.

Atividades

Vendas de carro novos

Vendas de carros usados

Peças de reposição

Oficina

$\mathrm{F} \& \mathrm{I}^{*}$

\section{Média (\%)}

45

20

18

10

15
Desvio padrão

17

13

8

7

14

* F\&I (Financing \& Insurance) refere-se aos ganhos com retorno do financiamento, venda de seguros, acessórios e outros serviços auxiliares. É considerado atualmente o quinto centro de resultados da concessionária.

Quanto à rentabilidade, 26\% das revendas tem rentabilidade entre 3,0 e 4,5. No geral, 60\% das revendas têm rentabilidade inferior a 4,5 (tabela 4.7). Não se verificou, na mostra estudada, evidência estatística de que haja correlação entre a rentabilidade e o tamanho da revenda para o nível de significância de $10 \%$. 
Tabela 4.7 - Rentabilidade do negócio.

\begin{tabular}{ll} 
Rentabilidade & $(\%)$ \\
\hline $0-1,5$ & 16 \\
$1,5-3,0$ & 26 \\
$3,0-4,5$ & 18 \\
$4,5-6,0$ & 13 \\
$6,0-7,5$ & 5 \\
Acima de 7,5 & 3 \\
\hline
\end{tabular}

\subsubsection{O Formato do Negócio}

A comercialização de carros usados é, conforme se levantou nas entrevistas realizadas nas associações de marcas, um dos pontos fracos das concessionárias. São poucas as que, na opinião dos entrevistados, sabem executar de forma lucrativa essa atividade ${ }^{26}$. No entanto eles acreditam que ela pode se tornar uma atividade rentável para a revenda, pois ela pode gerar serviços e compra de peças. Além disso, os compradores são potenciais consumidores de veículos novos após algum tempo. As montadoras em geral e a Fenabrave têm programas específicos para dar apoio ao concessionário nesse negócio. Tradicionalmente as revendas negociam os carros usados com o mesmo pessoal que negocia carros novos. Considerando a amostra estudada, em 50\% dos casos a comercialização de carros usados é feita dessa forma. Porém, numa parcela considerável (44\%) ela é feita na própria revenda com pessoal especializado em avaliação, compra e venda de usados sob uma gerência específica, o que já é uma mudança significativa, visto que o negócio de usados requer outra abordagem e tem características de venda diferentes do comércio de carros novos. Por exemplo, a atividade requer um cuidado maior que a venda de carros novos: existem problemas de que devem ser resolvidos no ato da negociação, como condições mecânicas e de conservação, problemas de documentação. Em um dos casos, ela é feita por empresa independente, especializada nesse tipo de negócio. Em outro caso, a comercialização de usados é feita pelo mesmo pessoal que comercializa carros novos, porém eles se reportam a um gerente de usados (tabela 4.8). Em contato direto, pós-questionário, com a revenda (através do respondente) esclareceu-se que os carros usados são comercializados no mesmo showroom de carros novos e pelos mesmos

\footnotetext{
${ }^{26}$ Ver também Fenabrave [...] (2001)
} 
vendedores, porém existe um gerente que cuida da comercialização. Os vendedores têm metas de vendas definidas mensalmente e recebem uma comissão, inferior à comissão paga pela venda de carro novo.

Tabela 4.8 - Comercialização de carros usados.

Formatos de negócio

Negociações feitas com o mesmo pessoal que comercializa carros novos

Negociações feitas por pessoal especializado da própria revenda, sob u ma gerência específica

Feita pela matriz

Feita por empresa especializada pertencente ao mesmo grupo econômico

Feita por empresa independente especializada em compra e venda de veículos usados

Feita pelo pessoal que comercializa carros novos que se reportam a uma gerência específica

$\mathrm{Na}$ amostra estudada, $66 \%$ dos serviços de funilaria são realizados integralmente nas revendas, porém, em 34\% buscam-se outras formas de executar os serviços. Numa das formas os serviços são realizados por terceiros (subcontratação de mão-de-obra), porém na própria concessionária, usando a estrutura existente. Em outra, os serviços são realizados por terceiros e há ainda o formato misto, no qual uma parte do serviço é realizada na revenda e a outra parte em empresa especializada (tabela 4.9).

Tabela 4.9 - Formatos de negócio.

\begin{tabular}{|c|c|c|c|}
\hline Formas de execução das funções & $\begin{array}{l}\text { Funilaria } \\
\qquad(\%)\end{array}$ & $\begin{array}{c}\text { Oficina } \\
\text { Mecânica } \\
(\%)\end{array}$ & $\begin{array}{c}\text { Serviços } \\
\text { Rápidos } \\
(\%)\end{array}$ \\
\hline Na concessionária, pelo pessoal da própria concessionária & 66 & 89 & 66 \\
\hline $\begin{array}{l}\text { Na concessionária, porém por empresa especializada que utiliza a } \\
\text { estrutura existente }\end{array}$ & 13 & - & 11 \\
\hline Feita pela matriz & - & - & - \\
\hline Em outra concessionária da mesma marca & - & - & - \\
\hline Em empresa especializada pertencente ao mesmo grupo econômico & 5 & - & 3 \\
\hline Em empresa independente especializada nesse tipo de negócio & 8 & 3 & 20 \\
\hline Serviço realizado na revenda e em empresa especializada & 8 & 8 & - \\
\hline
\end{tabular}

Nas entrevistas com os revendedores, levantou-se que a funilaria era um dos pontos deficientes da revenda em termos de custos e qualidade de serviços. Em primeiro lugar porque 
é difícil manter as atualizações em tecnologia e equipamentos- estamparia, estufas, pintura e pessoal-, necessários para oferecer serviços com custo e qualidade comparáveis às redes de funilarias independentes. Em segundo lugar, porque os serviços de funilaria são muito dependentes das seguradoras de veículos: elas pagam abaixo dos preços de mercado pelos serviços e pelas peças e ainda oferecem uma série de vantagens para o proprietário que levar o carro na oficina indicada por eles, como por exemplo, redução da franquia, carro reserva, parcelamento da franquia etc.

Os serviços rápidos (alinhamento, balanceamento, troca de pneus) também são considerados um dos aspectos importantes para as revendas. Eles são pouco explorados pelos revendedores e de maneira geral ficam abaixo das expectativas dos clientes em termos de qualidade, preço e rapidez (ver item 2.2.3). Em 66\% da amostra os serviços rápidos são realizados na própria revenda, porém em 34\% os serviços são terceirizados. Em alguns casos eles são realizados na própria concessionária por empresa de serviço automotivo especializada que utiliza a estrutura existente (terceiriza mão-de-obra); em outros, por empresa de serviço automotivo especializado seja independente ou pertencente ao mesmo grupo econômico (tabela 4.9).

Os principais motivos alegados pelos entrevistados foram a maior rapidez e a qualidade dos serviços oferecidos pelos centros automotivos. Além disso, as concessionárias não precisam investir em atualização de equipamentos e software.

Já os serviços mecânicos propriamente ditos, $89 \%$ das revendas amostradas executam-nos na própria revenda. Nos demais casos eles são realizados por empresa independente especializada nesse tipo de serviço ou de forma mista, com as revendas executando uma parte dos serviços e recorrendo a empresas especializadas independentes ou pertencentes ao mesmo grupo econômico para complementação (tabela 4.9).

Em 50\% dos casos, as empresas que têm algum tipo de terceirização dos serviços de oficina responderam que houve resistência da montadora à terceirização dessa atividade (tabela 4.10). Os outros $50 \%$ não responderam a questão referente à resistência da montadora. Dois respondentes, que não terceirizam essa atividade, informaram que pretendiam fazê-lo, mas desistiram devido à forte objeção da montadora. Esses respondentes terceirizam outros serviços. Para as outras atividades - funilaria, serviços rápidos e comercialização de usados-, as revendas que têm algum tipo de terceirização declararam que não houve resistência da 
montadora à terceirização (tabela 4.10). Isso sugere que as montadoras vêem os serviços de oficinas mecânica mais fortemente relacionados à marca que os demais.

$\mathrm{Na}$ amostra estudada, houve participação das montadoras do processo de terceirização das atividades em apenas $15 \%$ dos casos onde houve terceirização das atividades de funilaria (tabela 4.10). Esses dados sugerem que o processo de terceirização de certas atividades não se trata de uma ação coordenada das montadoras no sentido de aumentar a eficiência do canal como um todo, mas sim um movimento do próprio varejo.

Com relação à existência de contratos formais, a exceção da comercialização de carros usados e da funilaria, há pouca existência de contratos formais entre as concessionárias e os prestadores de serviços automotivos (tabela 4.10). Fato que pode resultar em uma menor padronização/qualidade dos serviços prestados, visto que não há garantias formais para que os serviços sejam executados dentro de certos padrões.

Tabela 4.10 - Aspectos gerais das terceirizações.

\begin{tabular}{lcccc}
\hline Aspectos & $\begin{array}{c}\text { Funilaria } \\
(\%)\end{array}$ & $\begin{array}{c}\text { Comer. de } \\
\text { carros usados } \\
(\%)\end{array}$ & $\begin{array}{c}\text { Oficina } \\
(\%)\end{array}$ & $\begin{array}{c}\text { Serviços } \\
\text { rápidos } \\
(\%)\end{array}$ \\
\hline $\begin{array}{l}\text { Existência de contrato formal entre revenda e } \\
\text { prestador de serviços }\end{array}$ & 38 & 100 & 25 & 26 \\
$\begin{array}{l}\text { Participação da montadora na terceirização } \\
\text { Resistência da montadora }\end{array}$ & 15 & - & - & - \\
\hline
\end{tabular}

Porém, todas as concessionárias que tercerizaram em algum grau as atividades acima declararam que obtiveram benefícios. Os principais foram: a redução de custos e a maior rapidez no atendimento (gráfico 4.3). 


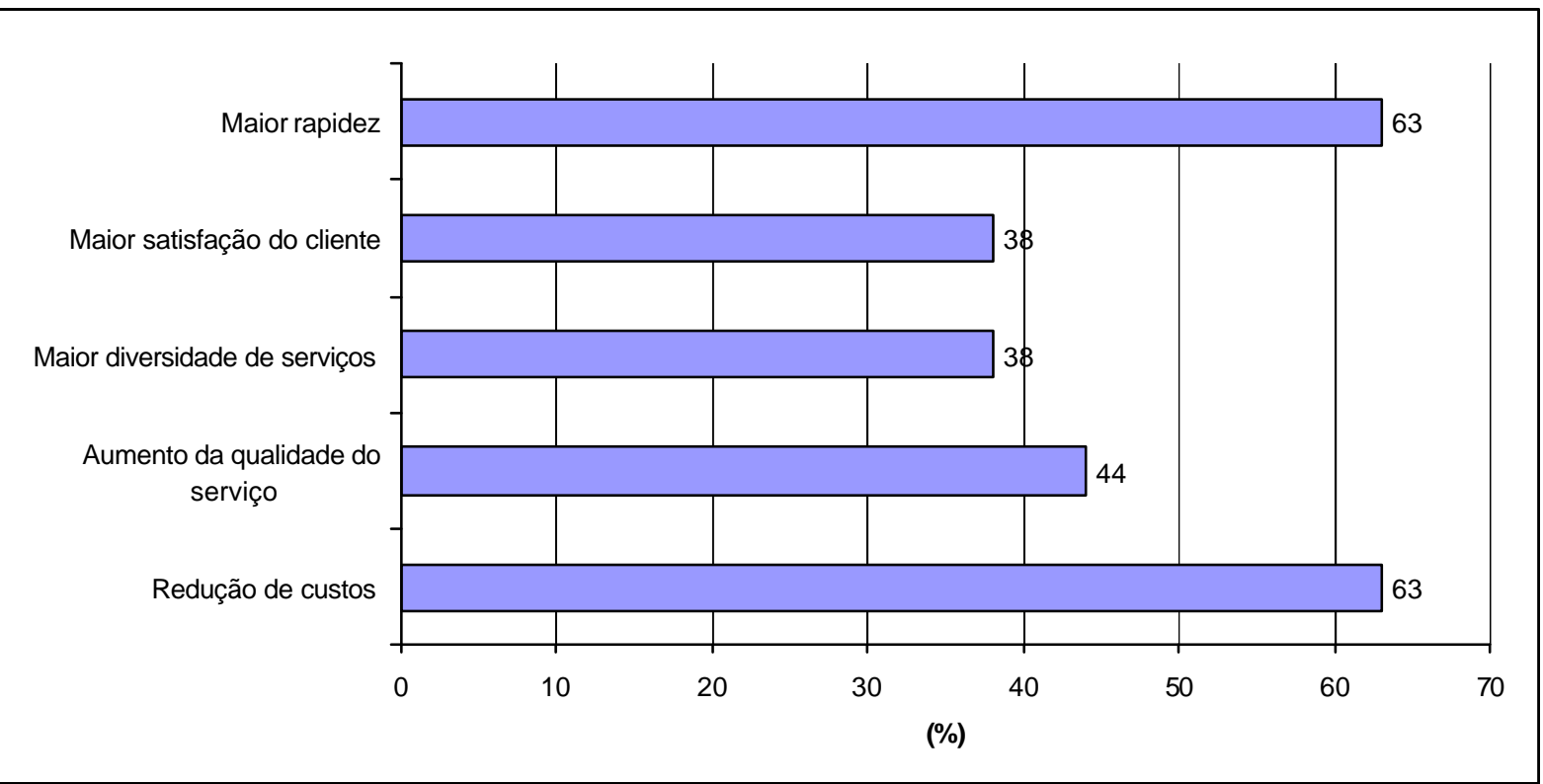

Gráfico 4.3 - Benefícios obtidos com a terceirização.

Em resumo, todas as revendas da amostra pesquisada possuem showroom organizado e setor de peças de reposição. No entanto, quando se consideram as demais funções comercialização de carros usados e especialmente as de assistência técnica e reparo-, há variações. Pode-se identificar 3 estratégias distintas: as revendas que mantém a estrutura clássica, com as funções agregadas em um só local; as revendas que terceirizam completamente certos serviços; as revendas que mantêm todas as funções agregadas, porém terceirizam parte dos serviços. No geral, $48 \%$ das revendas estudadas apresentarem algum grau de terceirização de seus serviços.

Os resultados sugerem que, ao propiciar a redução de custos e de prazo (gráfico 4.3), a terceirização acaba tendo impacto positivo sobre o negócio e sua lucratividade, por exemplo, a rapidez pode ser arma para ganhar participação no mercado. Ainda que a amostra não permita inferências estatísticas rigorosas, os dados sugerem que há correlação positiva entre a oficina e a rentabilidade: seriam mais rentáveis as concessionárias que exploram melhor os serviços de oficina ${ }^{27}$.

Os resultados apresentados no gráfico 4.3 também sugerem que para os casos onde existe algum grau de terceirização houve um aumento do nível de serviço no canal com uma maior

\footnotetext{
${ }^{27}$ Um teste estatístico, com nível de significância de $10 \%$ mostra coeficiente de correlação positivo de 0,39 .
} 
da rapidez na prestação do serviço (menor tempo de espera). Essa terceirização também pode estar provendo os consumidores com serviços complementares que não seriam normalmente oferecidos na situação de integração total das funções. No entanto, isso é uma hipótese que carece de investigação mais aprofundada.

Com base nesta amostra, pode-se analisar a proposição de Mercer (1994) e Chanaron e Jullien (1999) de que a desagregação de funções traria vantagens para distribuição de veículos. Um resultado importante é a alegada redução de custos e prazos (gráfico 4.3). Para uma avaliação mais geral algumas ressalvas devem ser feitas: em primeiro lugar a amostra é pequena, assim, uma ampliação da amostra poderá trazer à tona outras evidências; em segundo lugar, o processo de terceirização é recente e seus impactos sobre o negócio da revenda são ainda imprecisos; em terceiro lugar, a rentabilidade do negócio pode estar mais fortemente associada a outros fatores que não foram investigados neste trabalho como a definição de mix de produtos e serviços, a estratégia de marketing etc; quarto, a decisão de terceirizar depende do conhecimento dos custos de cada atividade e do impacto nos ganhos totais da revenda.

Neste ponto pode-se retomar a proposição P1 deste trabalho: as concessionárias de automóveis novos no Brasil estão se reestruturando, buscando terceirizar algumas de suas funções ou compartilhar recursos a fim de recuperarem suas margens e rentabilidade. Os resultados apresentados nas tabelas 4.8 e 4.9 e no gráfico 4.3 sustentam essa proposição. No entanto, em função da limitação da amostra não se pode dizer que há uma tendência em desintegrar as funções da revenda. $O$ que se observa são outros formatos de negócio coexistindo com o formato tradicional de concessionária.

\subsubsection{Relação concessionária - montadora}

$\mathrm{O}$ aspecto relacionamento entre fabricantes e distribuidores envolve uma série de fatores, como a interdependência dos agentes, a estrutura de comunicação, o suporte dado aos distribuidores, os incentivos e a familiaridade dos fornecedores com o negócio dos distribuidores. A adoção de posturas mais cooperativas é, segundo Bowersox e Cooper (1992), fundamental para que os objetivos de estímulo e atendimento da demanda sejam alcançados. 
Segundo Silva e Alcântara (2001), nas relações mais cooperativas entre fabricantes e distribuidores, as negociações começam a ser feiras em bases anuais e contam com a presença de dos níveis hierárquicos mais altos. Além de preço e volume são discutidas estratégias conjuntas de lançamento de produtos e serviços.

$\mathrm{Na}$ amostra de revendas estudada, 44\% declararam que as negociações contam com a presença de altos executivos das montadoras. A definição de metas conjuntas de vendas e de lançamento de produtos aparecem em menor proporção, $23 \%$ e $16 \%$ respectivamente, assim como a definição conjunta de serviços (21\%) (tabela 4.11).

Tabela 4.11 - Aspectos que envolvem a relação com a montadora.

\begin{tabular}{|c|c|c|}
\hline Aspectos & $\begin{array}{l}\operatorname{Sim} \\
(\%)\end{array}$ & $\begin{array}{l}\text { Não } \\
(\%)\end{array}$ \\
\hline Negociações contam com a presença de altos executivos da montadora & 44 & 66 \\
\hline Metas de vendas definidas pelo fabricante em conjunto com o revendedor & 23 & 77 \\
\hline $\begin{array}{l}\text { Estratégia de lançamento de novos produtos é definida pelo fabricante em conjunto } \\
\text { com o revendedor }\end{array}$ & 16 & 84 \\
\hline Serviços são definidos pelo fabricante em conjunto com o revendedor & 21 & 79 \\
\hline $\begin{array}{l}\text { A montadora dá suporte à revenda em áreas como gestão financeira, custos, gestão } \\
\text { de estoques, gestão da qualidade e vendas }\end{array}$ & 64 & 36 \\
\hline $\begin{array}{l}\text { A montadora dá retorno aos revendedores dos resultados das pesquisas de opinião } \\
\text { sobre o atendimento que realiza com os consumidores }\end{array}$ & 95 & 5 \\
\hline $\begin{array}{l}\text { Comparando com o passado recente, a montadora hoje é mais flexível quanto ao } \\
\text { sistema de quotas }\end{array}$ & 90 & 10 \\
\hline $\begin{array}{l}\text { Reuniões regionais com altos executivos das montadoras para serem divulgadas as } \\
\text { políticas e decisões sobre a distribuição }\end{array}$ & 72 & 2 \\
\hline Comitê de aconselhamento & 8 & 21 \\
\hline
\end{tabular}

O suporte aos distribuidores é outra questão central na construção de relacionamentos mais cooperativos entre distribuidores e fabricantes (ROSEMBLOON, 1999; FITES, 1996). Sobre esse aspecto, $64 \%$ das revendas declararam que estão recebendo suporte das montadoras em gestão financeira, custos, gestão de estoques, qualidade e vendas (tabela 4.9). Outros tipos de suporte como treinamento e apoio promocional também foram citados por parte significativa das revendas (gráfico 4.4). 
A estrutura de comunicação é outro elemento importante na construção da cooperação e da confiança entre os membros do canal de distribuição (ANDERSON; WEITZ, 1994; KUMAR, 1996). Essa estrutura não se refere somente ao grau de informatização e ao uso das tecnologias da informação, mas aos mecanismos que permitam a difusão das políticas e decisões sobre a distribuição e espaços onde os membros do canal possam recorrer para exporem suas necessidades e dificuldades como são os comitês de aconselhamento. Nesse sentido, $72 \%$ das revendas da amostra declararam que são realizadas reuniões para divulgação das políticas e decisões sobre distribuição. A maioria absoluta das revendas (95\%) alegou que recebe retorno das montadas das pesquisas sobre qualidade do atendimento da concessionária realizadas junto ao consumidor. Um fato que, segundo se levantou nas entrevistas com os revendedores, vem se intensificando nos últimos anos.

Quanto à existência de comitê de aconselhamento, houve um grande número de não respostas (56\%), e $21 \%$ diz não possuir um comitê de aconselhamento (tabela 4.11), sugerindo um desconhecimento desse mecanismo por parte dos respondentes. Nas entrevistas com os revendedores apurourse que, embora hoje eles recebam muito mais informação das montadoras no que se refere à distribuição e lançamento de novos produtos, eles são ainda pouco ouvidos por elas.

O sistema de atribuição de cotas, responsável por empurrar os carros para o revendedor, foi um dos pontos de maior pressão da montadora sobre os revendedores. No entanto, $90 \%$ das revendas responderam que hoje a montadora é mais flexível sobre esse aspecto.

Segundo pode-se levantar nas entrevistas realizadas com os concessionários, há diferenças na profundidade e na velocidade das mudanças sobre esse aspecto dependendo da montadora. Grosso modo, as principais mudanças relatadas são:

- antes o aspecto mais importante era o volume e os concessionários tinham pouco controle sobre o mix de produtos que recebiam. Atualmente ainda existe a pressão por volume, especialmente das montadoras mais antigas, mas já se fala em metas de vendas que são determinadas em função do market share tendo por base o número de emplacamentos de cada região. Dos 11 concessionários entrevistados, 8 declararam que hoje eles têm maior controle sobre o mix de produtos que recebem. Ainda ocorrem entregas de mix de produtos diferente do solicitado, mas em menor proporção que no passado recente. Dois revendedores que representam duas das montadoras mais antigas declararam que está 
havendo mudanças na área comercial das montadoras. Essas mudanças são lentas e estão ocorrendo desde o nível de diretoria até o de funcionários.

- alongamento do prazo de floor plan. Antes as montadoras trabalhavam em média com prazos de 30 a 60 dias. Atualmente os prazos chegam a 120 dias e há casos em que se estendem até 180 dias;

- redução da prática das vendas casadas.

Segundo se levantou nas entrevistas com os concessionários, atualmente, as grandes áreas de atritos entre montadoras e distribuidores são margem e e/ou a falta de produtos novos.

A venda de carros novos depende da qualidade e da disponibilidade de serviços ao consumidor. Uma das características inerentes aos serviços é a variabilidade: os serviços dependem fortemente de quem fornece, de onde e de quando são oferecidos (SASSER; OLSEN; WYCKOFF, 1978; GIANESI; CORRÊA, 1994). E, conforme aponta Carlzon (1993), cada contado do cliente com o prestador de serviço é importante para a formação da imagem da marca. Para reduzir a variabilidade as empresas que dependem dos serviços para vender seus produtos utilizam uma série de estratégias como treinamento de pessoal, padronização do processo de execução dos serviços e monitoramento da satisfação do cliente.

O sistema de concessionárias existente no Brasil se assemelha muito ao sistema de franquias de marcas e produtos de segunda geração. Esse sistema é uma alternativa a integração vertical (WILLIAMSON, 1996). Nos casos das franquias de segunda geração, há o licenciamento do uso da marca e a obrigatoriedade de exclusividade na comercialização de produtos, porém, a forma de gerenciamento do negócio é de responsabilidade do franqueado, havendo portanto grande variação na forma de atendimento e gestão (RIZZI, 1996).

Os resultados da tabela 4.12 mostram que as montadoras no Brasil, seguindo uma tendência já observada no mercado americano desde meados da década passada (MERCER, 1994; HOFFMEISTER, 1995), têm imposto uma série de ações, como a padronização da aparência da loja, processo de vendas, atendimento na oficina e treinamento como forma de reduzir a variabilidade, controlar a qualidade dos serviços e melhorar o atendimento da rede de distribuição. 
Tabela 4.12 - Exigências das montadoras.

\section{Exigências}

$(\%)$

Padronização da aparência da loja

Padronização do processo de venda

62

Padronização do atendimento na oficina

95

Certificação da oficina

51

Certificação da concessionária

64

Treinamento de pessoal

95

Padrão de qualidade de atendimento

95

Uso de software específico para envio de dados à montadora

74

Adoção de programas específicos (certificação de usados, promoções, etc)

49

Os resultados apresentados na tabela 4.12 sugerem que o formato de varejo de carros novos no Brasil está se aproximando do modelo de franquia de negócio formatado. Nesse modelo, além da concessão dos direitos de utilização da marca, o franqueador transfere o modelo de negócio empregado, chegando a detalhes operacionais (RIZZI, 1996). É portanto um modelo mais rígido que o de segunda geração. O que se busca neste tipo de franquia é que certos aspectos diretamente relacionados à imagem da marca, como o ambiente e os produtos e serviços, respeitem uma certa padronização. Assim, esses dados indicam que as montadoras estão buscando estratégias para fortalecimento da marca.

Das entrevistas com os concessionários levantoutse que a exigência de padronização, sobretudo do processo de vendas e do atendimento na oficina, é maior entre as montadoras novas. No entanto, todos os entrevistados declararam que hoje as montadoras estão muito mais exigentes com a qualidade dos serviços e do atendimento que no passado recente.

Sobre as formas de obter cooperação, as montadoras estão utilizando motivações positivas como apoio promocional, prêmios, bônus e verbas para propaganda. Apenas $10 \%$ dos respondentes afirmaram sofre sanções negativas como ameaça de rescisão contratual (gráfico 4.4). 


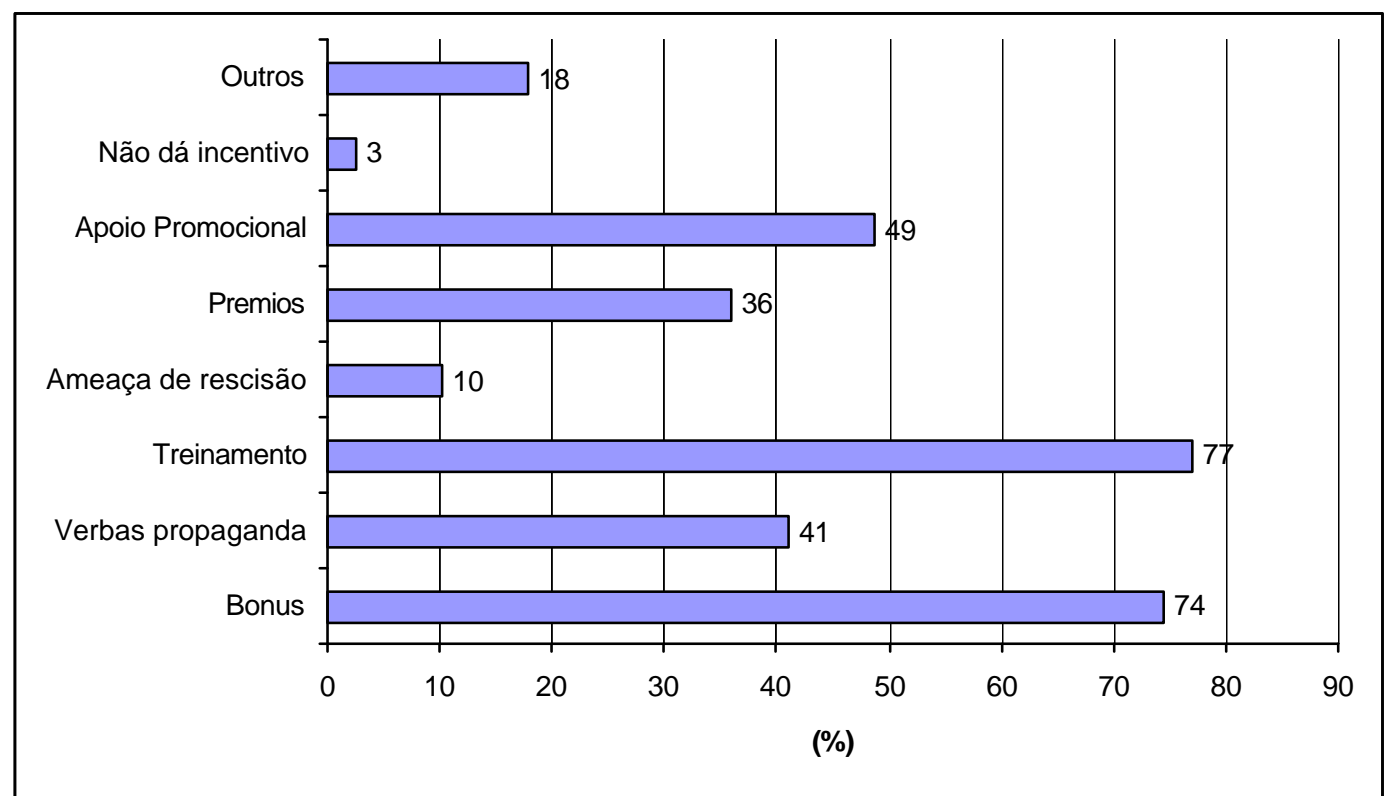

Gráfico 4.4 - Incentivo para promover as exigências da montadora.

Outros dados levantados nas entrevistas com os concessionários sobre a relação com a montadora são:

- quase todas as montadoras começam a estabelecer ações no sentido de monitorar a atuação dos revendedores fora das suas respectivas áreas de atuação no sentido de garantir uma certa exclusividade territorial aos seus revendedores;

- há uma tendência de redução do número de revendas por parte das montadoras mais antigas; e, no caso das montadoras novas uma tendência de expansão gradual da rede, mantendo um número reduzido de concessionárias;

- a existência de operação no atacado de menor risco para o concessionário, como a consignação (ver item 4.1);

A redução do número de distribuidores acompanhada de ações que garantam exclusividade territorial é, segundo Kumar (1996), indício de mudança no sentido de um relacionamento mais cooperativo. Essas ações seriam uma forma de aumentar o retorno dos distribuidores: menor número de concessionários tendo áreas exclusivas de atuação podem gerar volumes de vendas maiores e/ou mais adequados.

Pode-se, neste ponto, analisar a proposição P2: está havendo uma mudança no padrão de relacionamento entre montadora e rede de distribuição no sentido de construir relacionamentos mais cooperativos. Embora incipiente, já se pode observar a presença de elementos que são referência para a construção de relacionamentos mais cooperativos, como a 
presença de altos executivos nas negociações entre montadora e distribuidores; suporte da montadora aos revendedores em áreas como gestão financeira, vendas, gestão de estoques, etc., ênfase em treinamento, e mudanças em um dos pontos de maior atrito entre montadoras e revendedores que é o sistema de atribuição de cotas (tabela 4.11). Observa-se também ações para melhorar o desempenho da rede (tabela 4.12). Existe portando, evidências de que está se desenhando uma postura mais cooperativa entre montadoras e revendedores. No entanto, algumas ressalvas devem ser feitas: 1) o processo se encontra no início de seu desenvolvimento e parece que as novas montadoras estão à frente nesse processo; 2) existem diferenças entre as montadoras quanto a profundidade dessa mudança. Ela parace ser maior entre as mvas montadoras; e 3) o processo de mudança é lento. Existem aspectos culturais e econômicos a serem considerados e, como em todo o processo de mudança, a resistência é grande.

\subsubsection{Inovação nas revendas}

Os resultados a seguir referem-se à utilização das tecnologias da informação e de novas práticas de gestão pelas revendas.

Os sistemas de comércio-eletrônico permitem, através de um contato direto e interativo, saber sobre as necessidades dos clientes e seus padrões de comportamento: é possível registrar os eventos do relacionamento como os pedidos de informação sobre produtos e serviços, serviços ou produtos requeridos etc., que são aspectos importantes para os programas de marketing de relacionamento. É possível também estabelecer um outro canal de vendas, melhorando o nível de serviço ao cliente, como a disponibilidade 24 horas, a redução do tempo de espera etc. (O’ CONNEL, 2000; BARRENECHEA, 2001).

Das revendas que responderam ao questionário, $85 \%$ utiliza comércio eletrônico com os clientes. Das 6 revendas que ainda não têm comércio eletrônico, 4 declararam que já há previsão para a sua implantação. Entre os principais serviços oferecidos estão a busca de carros novos, as informações sobre financiamento e o agendamento de revisões (tabela 4.13). 
Tabela 4.13- Serviços oferecidos pelos sites das revendas na Internet.

Serviços

$(\%)$

Busca de carros novos

Busca de carros usados

Informações sobre financiamento

Agendamento de revisões

56

Disponibilidade de peças de reposição

44

Páginas de entretenimento

Outros 3

O uso das tecnologias da informação pode propiciar às empresas um melhor controle e interação das atividades, além de suprir os gestores com informação para a tomada de decisão (STAIR, 1998). A maioria das empresas faz uso de banco de dados e e-mail interno. Já o uso de sistemas integrados de gestão (ERP) é pouco disseminado entre as revendas (gráfico 4.5). Mais da metade das revendas (56\%) tem Intranet. Já a Extranet é utilizada por $33 \%$ das revendas.

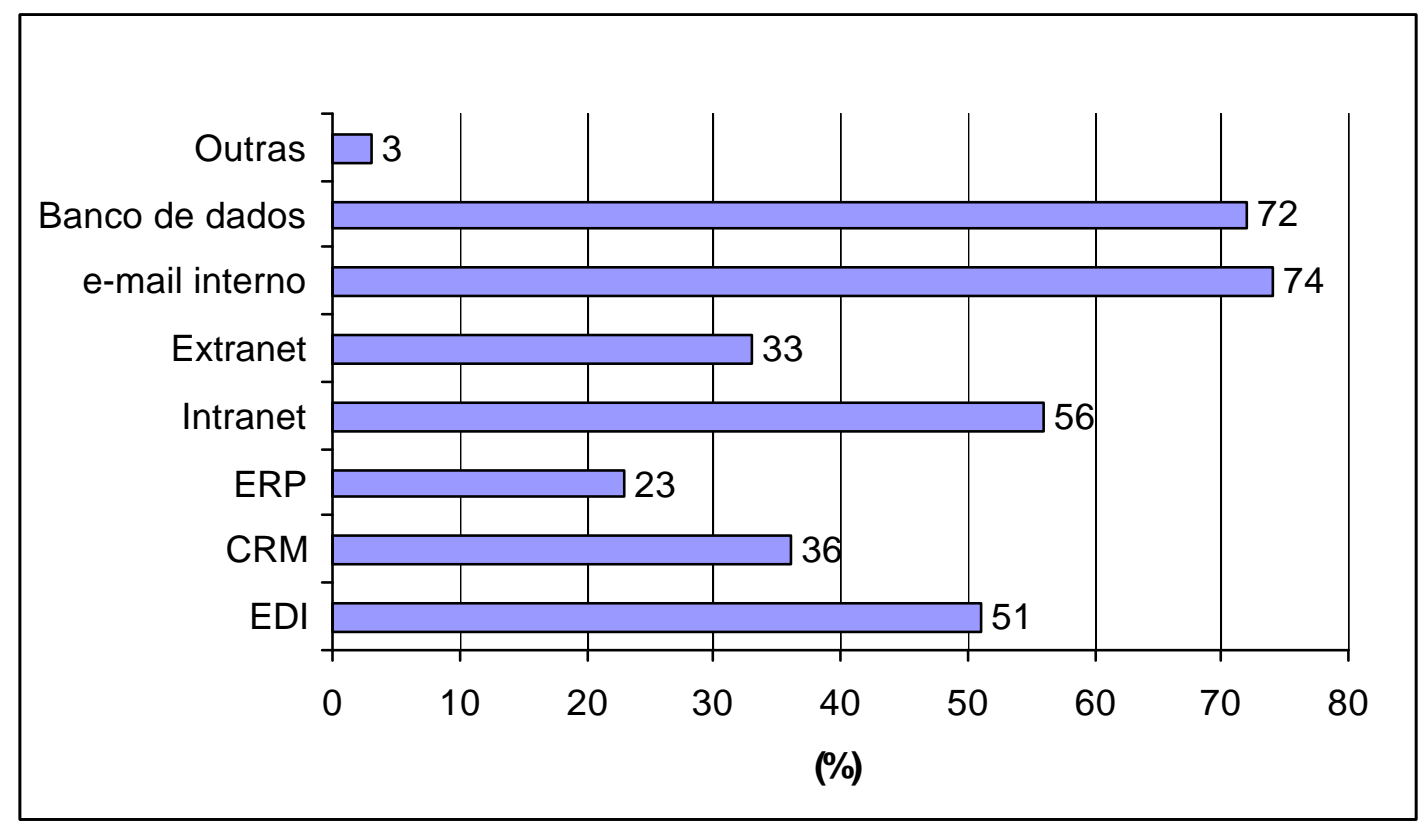

Gráfico 4.5 - Tecnologias da informação utlizadas pelas revendas. 
Entre as tecnologias da informação que podem trazer melhorias na coordenação entre os agentes do canal, principalmente no que diz respeito a adaptações às mudanças do mercado, o Electronic Data Interchange (EDI), que permite a troca de informações entre produtores, atacadistas e varejistas, é o mais utilizado. O CRM, que possibilta a gestão do relacionamento com o cliente aparece em menor proporção. (gráfico 4.5).

De forma geral, as concessionárias já informatizaram ou estão em processo de informatização de alguns de seus principais processos (tabela 4.14). A aplicação de sistemas informatizados em estoques está presente na maioria absoluta das revendas, refletindo a preocupação constantemente citada pelos concessionários da necessidade de melhor controle sobre peças de reposição, dado o volume de itens e o dinheiro empatado. Outras aplicações que aparecem na maior parte das revendas são em compras e em processamento de pedidos/serviços. De outro lado, nota-se que a maioria das revendas não possui ainda informatizado o processo de obtenção de informação sobre as necessidades dos clientes.

Tabela 4.14 - Grau de informatização dos processos nas revendas.

\begin{tabular}{lccc}
\hline Processos & $\begin{array}{c}\text { Total } \\
\text { Infor. } \\
(\%)\end{array}$ & $\begin{array}{c}\text { Em } \\
\text { processo } \\
(\%)\end{array}$ & $\begin{array}{c}\text { Nuda } \\
(\%)\end{array}$ \\
\hline Administração de estoques & 90 & 4 & 5 \\
Solicitação de compras & 69 & 15 & 15 \\
Recebimento de mercadorias & 69 & 15 & 15 \\
Emissão de documentos de compras & 82 & 10 & 8 \\
Envio de pagamento & 82 & 8 & 10 \\
Planejamento de serviços & 62 & 15 & 15 \\
Controle de serviços & 79 & 13 & 8 \\
Solicitação de serviços & 79 & 15 & 6 \\
Obtenção de informação sobre as necessidades dos clientes & 44 & 30 & 26 \\
Emissão de documentos de vendas & 82 & 10 & 8 \\
\hline
\end{tabular}

Em termos de práticas de gestão nota-se que as revendas estão se movendo no sentido de adotarem programas considerados relevantes dentro das novas práticas de gestão. A maioria já implantou ou está em processo de adoção de programas de qualidade, satisfação do cliente e 
de indicadores de desempenho. Porém, é relativamente baixa a parcela de revendas que possuem implantados programas de fidelização (tabela 4.15).

Tabela 4.15- Adoção de novas praticas de gestão.

\begin{tabular}{lccc}
\hline Práticas & $\begin{array}{c}\text { Implantado } \\
(\%)\end{array}$ & $\begin{array}{c}\text { Em } \\
\text { implantação Previsão } \\
(\%)\end{array}$ & $\begin{array}{c}\text { Sem } \\
(\%)\end{array}$ \\
\hline Programa de qualidade & 50 & 28 & 23 \\
Programa de satisfação do cliente & 67 & 18 & 14 \\
Programa de fidelização & 36 & 30 & 34 \\
Programa de capacitação de recursos humanos & 36 & 32 & 32 \\
Implantação de indicadores de desempenho & 56 & 18 & 26 \\
\hline
\end{tabular}

A qualidade do serviço, da pré-venda ao pós venda, é um aspecto importante para os canais de distribuição (STERN; EL-ANSARY; COUGHLAN, 1996). Os intermediários devem procurar superar constantemente as expectativas dos clientes. Daí a importância da implantação dos programas de qualidade e de satisfação dos clientes nas empresas que, com suas abordagens, ferramentas e técnicas, desenvolvam o compromisso com qualidade em toda a organização (REICHHELD; SASSER, 1990). Com relação às revendas, a satisfação do cliente especialmente com os serviços de pós- venda é um dos fatores de fidelização não só à loja, mas também à marca, como apontado por Urdan e Zuñiga (2001). Na amostra de revendas estudadas, $50 \%$ já tem implantado programas de qualidade e $67 \%$ já implantaram programas de satisfação de clientes (tabela 4.15).

Para acompanhar e avaliar os impactos de suas iniciativas e redirecionar suas ações, as empresas necessitam de um conjunto de indicadores de desempenho que lhes permitam gerenciar seus principais processos. Segundo Kaplan e Norton (1996), esse conjunto de indicadores não deve ficar restrito apenas aos indicadores de eficiência econômica, como por exemplo, o retorno sobre o investimento, ou a performance interna da organização como qualidade, tempo de resposta, etc, mas deve abranger também a relação com os clientes, como o nível de satisfação, o índice de retenção, market share, e a capacidade de aprendizado da empresa, como a qualificação dos empregados, o nível de motivação, o nível de comunicação e informação etc. Das revendas pesquisadas, $56 \%$ implantaram algum conjunto de indicadores de desempenho (tabela 4.15). 
Com o surgimento de novas marcas, a fidelidade à marca está diminuindo, pois os consumidores estão mais dispostos a experimentar novas marcas, assim, aumenta a importância das características do ponto de venda no processo de compra. Segundo Fournier, Dobscha e Mick (1998) uma redução da taxa de perdas de clientes inferior a 5\% pode resultar em um incremento nos lucros de até 85\%. Nesse sentido, a adoção de programas de fidelização aparece como um aspecto importante. Porém, uma parcela significativa das revendas ainda não se moveu nesse sentido. Apenas 36\% das revendas pesquisadas possuem programas de fidelização (tabela 4.15). Tais programas são um dos pilares do marketing de relacionamento, que tem por objetivo a busca de um relacionamento constante e eficiente entre a empresa e seus clientes. Eles se apoiam no conhecimento do perfil e das necessidades dos clientes, na comunicação contínua e no uso de banco de dados.

O sucesso na introdução de novas tecnologias e de programas da qualidade e de fidelização depende do nível de qualificação do pessoal. Muitas vezes é necessário desenvolver novas habilidades, novos comportamentos e atitudes ou promover uma mudança do perfil dos recursos humanos envolvidos (KAPLAN; NORTON, 1996). No caso específico de empresas prestadoras de serviços, como é o caso das concessionárias, a presença contínua do cliente (consumidor) no processo de produção de serviço torna a capacitação dos recursos humanos um aspecto ainda mais relevante (KELLOGG; NIE, 1995). No entanto, apenas 36\% das revendas têm um programa de capacitação de recursos humanos implantado.

Todas as revendas pesquisadas vêm experimentando outras formas de vendas para atingir diferentes segmentos de clientes e aumentar o volume de vendas. Visitas externas e feirões são amplamente usados pelos revendedores, conforme mostra o gráfico 4.6 abaixo. 


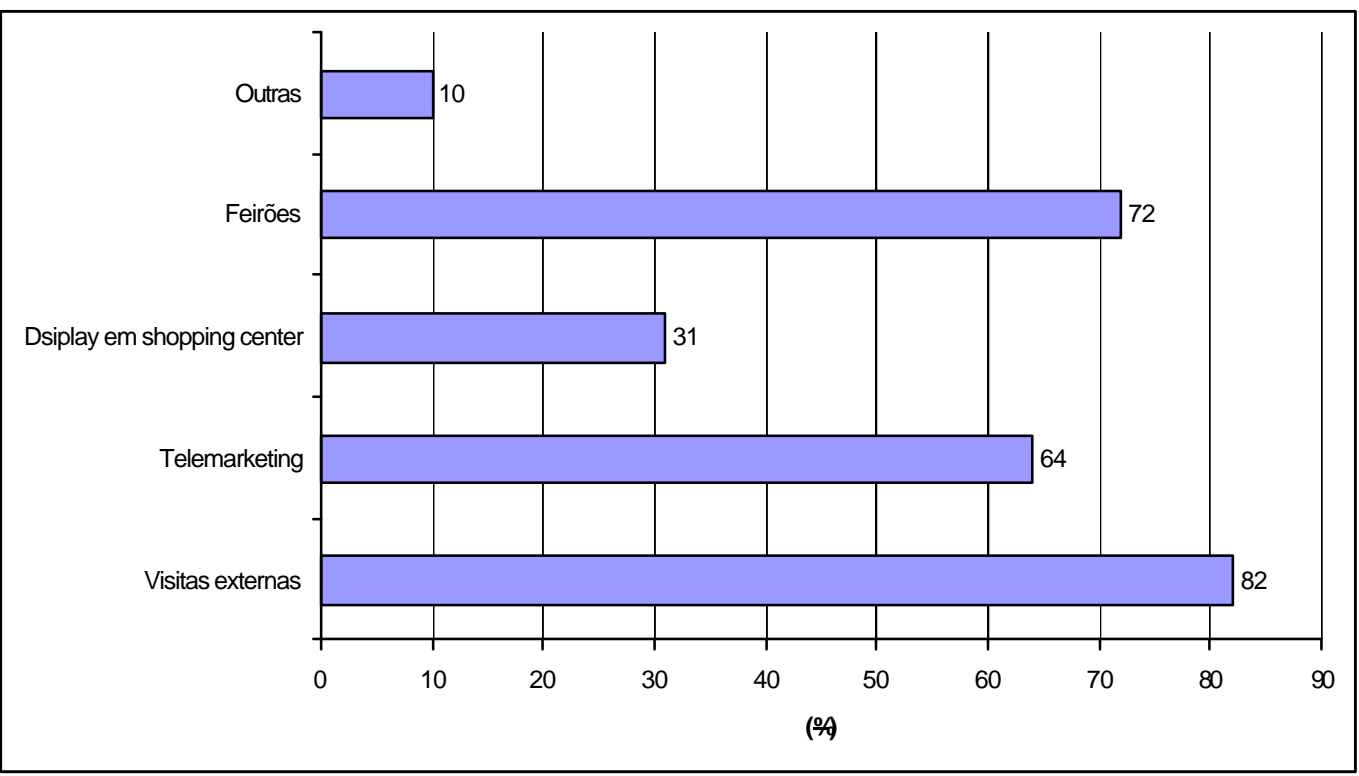

Gráfico 4.6 - Formas alternativas de vendas.

O mix de serviços é uma das ferramentas-chave para diferenciar uma loja da outra. (KOTLER, 2000). Segundo Rocha e Veloso (1999), especial atenção deve ser dada aos serviços de pós-venda, pois são estes que no médio prazo criam a verdadeira imagem da empresa e por isso são importantes para a fidelização dos clientes. Acredita-se que os serviços relacionados terão grande importância na recuperação da rentabilidade do negócio e na fidelização dos clientes das revendas (CRIATIVIDADE...,2001). Seguindo uma tendência já observada nas revendas americanas e européias ${ }^{28}$, as revendas estão oferecendo um mix de serviços auxiliares de pós-venda. No geral, alguns serviços como venda de seguros, licenciamento, financiamento, instalação de acessórios e embelezamento estão presentes em quase a totalidade da revendas. Outros serviços, mais relacionados com o ambiente e da loja, como boutique e lojas de conveniência já começam a aparecer. Verifica-se também uma tendência entre as empresas pesquisadas de terceirizar financiamento, venda de seguros e licenciamento e de manter certos serviços de pós-venda como instalação de acessórios e assistência técnica com atendimento domiciliar (tabela 4. 16).

\footnotetext{
${ }^{28}$ Ver $<$ http://www.dealeronline.com.br/ed37/print/capa/ capa.htm
} 
Tabela 4.16 - Serviços oferecidos pelas revendas.

\begin{tabular}{llc} 
Serviços & $(\%)$ & $\%$ terceirizado \\
\hline Financiamento & 97 & 77 \\
Vendas de seguro & 97 & 79 \\
Licenciamento & 92 & 87 \\
Lojas de conveniência & 41 & 18 \\
Instalação de acessórios & 97 & 23 \\
Assistência técnica com atendimento domiciliar & 77 & 13 \\
Embelezamento (espelhamento, cristalização, etc) & 85 & 56 \\
Boutique & 46 & 8 \\
\hline
\end{tabular}

Cerca de $34 \%$ das revendas alegaram que pretendem implantar novos serviços. Nesses casos foram citados basicamente serviços de pós-venda: serviços rápidos, agendamento de serviços, instalação de acessórios e embelezamento.

Com base nesses resultados, pode-se analisar a proposição P3 deste trabalho: as concessionárias de automóveis no Brasil estão inovando através da adoção de novas práticas de gestão, da utilização das tecnologias da informação e da ampliação dos serviços oferecidos aos clientes. Dos resultados obtidos tem-se: 1) a maior parte das revendas se move no sentido de adotar programas como os de qualidade e de satisfação do cliente e indicadores de desempenho, que são elementos importantes para a melhora da performance da organização (tabela 4.15); 2) a maior parte das revendas da amostra faz uso de tecnologias da informação que dão apoio ao monitoramento, à realização das negociações e à ampliação da comunicação interna (processos informatizados, banco de dados, Intranet etc). Tem também uma certa infraestrutra que possibilita maior integração com seus fornecedores e o desenvolvimento de relacionamento com os clientes (comércio eletrônico, EDI). Ou seja, nestes aspectos, pode-se dizer que elas estão seguindo uma tendência já observada em outros seguimentos de varejo (tabelas 4.13 e 4.14 ).

Assim, a princípio, pode-se dizer que esses resultados sustentam a proposição P3. Contuto, algumas ressalvas devem ser feitas. Para que a adoção de novas tecnologias e de programas 
como o de qualidade seja bem sucessida é importante que eles estejam alinhados às estratégias da empresa. No entanto, os resultados sugerem que existem problemas de estratégia e de gestão e que essas iniciativas não estão no momento devidamente articuldas. Por exemplo, parece que são poucos os que têm percepção das vantagens que podem obter utilizando as informações sobre a demanda de seus produtos e serviços. A maioria das revendas tem infraestrutura de tecnologia de informação para coletar e armazenar essas informações de seus clientes (sistemas de comércio eletrônico e banco de dados), porém poucas desenvolvem programas de fidelização. Além de preço e qualidade dos produtos, os consumidores fazem seus julgamentos com relação ao mix e à qualidade dos serviços oferecidos pelas empresas. No entando, metade das revendas ainda não possui programas de qualidade implantados.

Outro aspecto que chama a atenção é que o uso efetivo dessas tecnologias e a aplicação bem sucedida de programas como os de qualidade dependem, em grande parte, da habilidade e motivação dos envolvidos. Todavia, são poucas as revendas que têm programas de capaciatação já implantados. Assim, a forma como as tecnologias da informação estão sendo utilizadas, as novas prátivas de gestão que estão sendo adotadas e os impactos dessas iniciativas sobre a revenda necessitam de investigação mais aprofundada.

\subsubsection{Sobre o negócio}

As redes de concessionárias estão enfrentando um mercado cada vez mais competitivo com a entrada de franquias nacionais e estrangeiras de prestação de serviços automotivos como os centros automotivos e as redes de funilarias e outros canais de venda como os sites de comércio eletrônico. Procura-se, a seguir, ter uma visão das preocupações das revendas sobre esses aspectos.

Centros automotivos, oficinas independentes e mercado independente de reposição são comumente citados como os principais concorrentes das redes de concessionárias. Na percepção dos concessionários, as oficinas independentes são os principais concorrentes, enquanto que os sites de vendas pela Internet são os que oferecem menos concorrência (gráfico 4.7). 


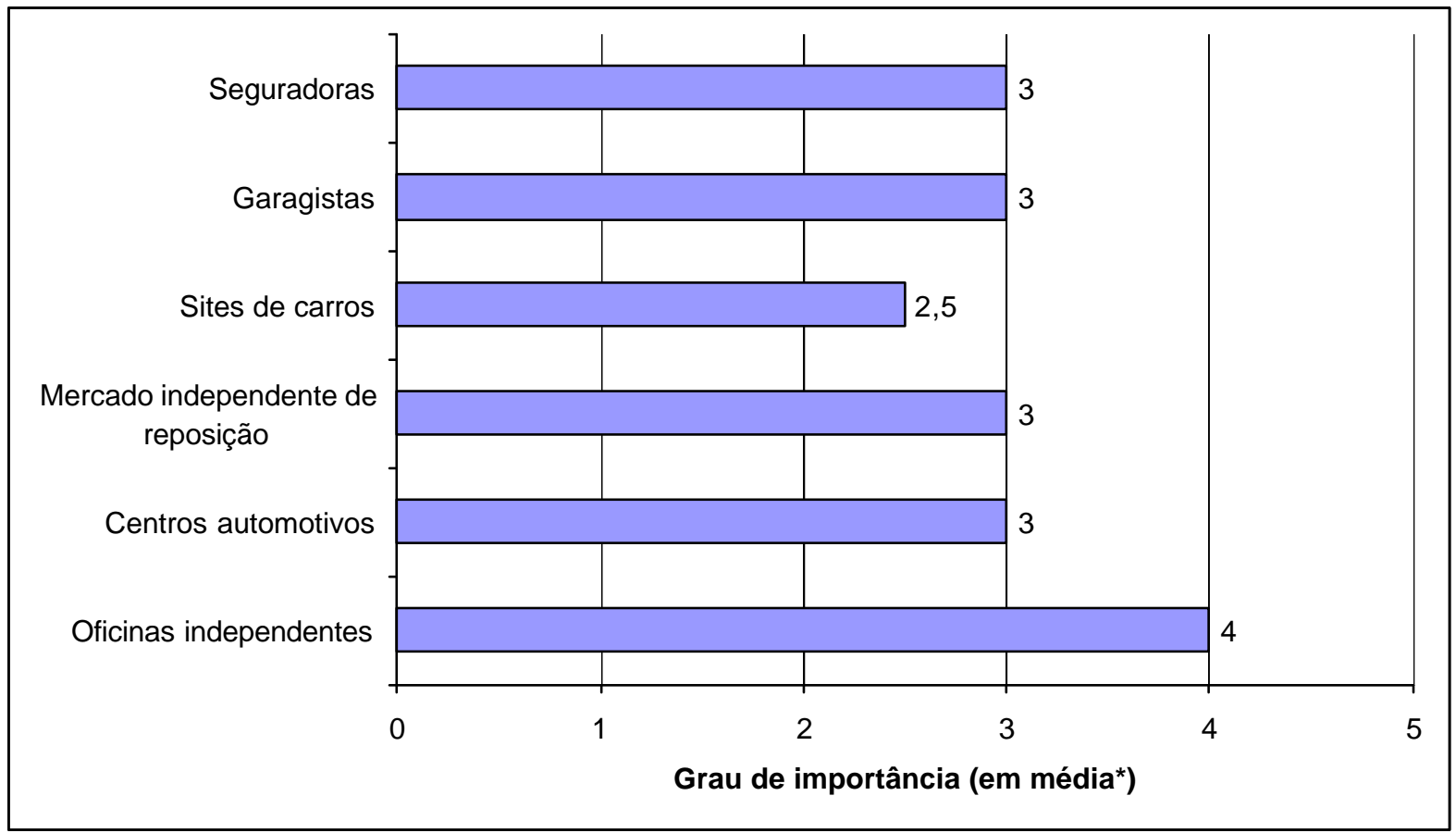

Gráfico 4.7 - Principais concorrentes das redes de concessionárias.

*Avaliação obtida segundo uma escala com valor máximo de 5, onde: 5 é extremamente importante e 1 sem importância.

As oficinas independentes preocupam no momento os concessionários visto que eles perdem boa parte de seus clientes para elas após o termino da garantia dos veículos. Na avaliação dos próprios concessionários, isso ocorre devido principalmente aos altos preços da rede de concessionárias e à demora no atendimento. Os concessionários entrevistados alegam que os preços mais altos dos seus serviços se devem a: necessidades de atualizações constantes de equipamentos, software e de treinamento de pessoal; do mix de serviços auxiliares, como recepção, leva-e-traz, carros reservas etc.; e de exigências burocráticas e de estrutura física determinadas pela montadora para a operação da revenda. Outros motivos apontados são as práticas antigas de gestão, cultura dos concessionários e a pouca importância da atividade para a revenda até pouco tempo atrás, uma vez que a comercialização de carros novos mantinha o negócio.

Outro concorrente importante é o mercado independente de reposição (gráfico 4.7). O alto preço das peças originais é o fator principal que faz o consumidor migrar para mercado independente. Sobre esse ponto, os concessionários entrevistados, sobretudo os que representam as montadoras mais antigas, alegaram que as montadoras têm reduzido sistematicamente os preços das peças de reposição para os concessionários e têm alterado uma 
prática muito comum no passado de empurrar para os concessionários peças caras e de pouco uso que ficavam em seus estoques. Isso, somado ao uso de sistemas informatizados de gestão de estoques, tem contribuído para que a rede tenha preços competitivos nos itens de maior giro como embreagem, pastilhas de freios, amortecedores, escapamentos etc.

Considerando o total, as oficinas autorizadas e pontos de vendas de peças de todas as montadoras são cerca de 2000. Eles estão em total desvantagem numérica quando confrontados com os independentes: são cerca de 26 mil varejistas e cerca de 145 mil oficinas independentes ${ }^{29}$.

As montadoras têm se utilizado de 3 estratégias principais: investido na melhoria do atendimento no pós-venda, melhorados seus sistemas logísticos investindo em novos centros de distribuição de peças e fazendo campanhas promocionais como foi o Desafio Preço Justo da Ford, em que se pôde adquirir peças a preços equivalentes ao do mercado independente, e com o valor fixo de mão-de-obra. O que tem ocorrido nesses casos é que as montadoras entram com a redução do preço da peça e a concessionária com a redução do valor da mão-deobra. Outras ações são o estabelecimento de condições especiais para compras à vista, a prazo e financiada, implementação de programas de fidelização e de políticas como o custo fixo de revisão da Peugeot e extensão do tempo de garantia.

Do lado das concessionárias, pode-se observar o estabelecimento de políticas mais agressivas de comercialização de peças com promoções e condições especiais para aplicadores, ou políticas de comercialização conjunta de peças mais serviços nas oficinas, com kits de peças mais mão-de-obra. Apesar disso, hoje ainda as oficinas atendem praticamente os veículos no período de garantia e aqueles casos que não encontram solução na rede independente de oficinas. E mesmo assim, segundo os revendedores entrevistados ${ }^{30}$, a evasão dos proprietários de carros no período de garantia é grande.

Os revendedores acreditam que as constantes mudanças tecnológicas dos veículos e as dificuldades de acesso dos reparadores independentes às informações técnicas das montadoras

\footnotetext{
${ }^{29}$ Dados fornecidos pela Associação Nacional dos Distribuidores de Autopeças (ANDAP), referentes ao ano de 2002.

${ }^{30}$ Somente dois revendedores entrevistados deram números: de 30 a $35 \%$ dos proprietários de carros novos não retornam nem para a primeira revisão nas concessionárias.
} 
e a falta de acesso aos equipamentos de diagnose específicos vão acabar diminuindo a pressão das oficinas independentes, especialmente das pequenas, sobre a rede de concessionárias.

No entanto, o setor independente está se reestruturando também. Muitos varejistas de autopeças estão ampliando seus negócios e oferecendo serviços de reparos; existem reparadores independentes se organizando em grupos para compra de equipamentos. Há também no mercado brasileiro, empresas fabricantes de equipamento de diagnose que abrangem vários modelos, desde que não muito novos. Os próprios reparadores independentes estão se organizando no sentido de reivindicarem à Secretaria do Direito Econômico o acesso às informações técnicas das montadoras (ROSA, 2004), seguindo o caminho dos reparadores independentes americanos e europeus que já conseguiram alguns avanços nesse aspecto (ALVARENGA, 2003).

Os centros automotivos são apontados como fortes concorrentes das redes de distribuição. Eles estão aumentando a sua participação no mercado de serviços (PERSPECTIVAS...,2001). Novamente preço, rapidez e qualidade dos serviços são os principais motivos apontados pelos concessionários entrevistados para os centros automotivos estarem ganhando espaço no mercado com os serviços rápidos de balanceamento, alinhamento, ajuste de freios etc.(gráfico 4.7).

As seguradoras de veículos também são encaradas como fortes concorrentes da rede. Segundo alegam os concessionários, a quase totalidade dos carros são assegurados e as seguradoras têm as suas oficinas credenciadas e preferenciais. Elas têm uma política de preços bem definida para serviços de reparo e funilaria e oferecem vantagens aos seus clientes para aceitarem suas indicações.

Embora a comercialização de usados seja apontada como uma maneira das concessionárias recuperarem sua rentabilidade, e a maioria absoluta das revendas participantes da pesquisa explorarem essa atividade, sendo uma boa parte com vendedores e gerência específica para isso (ver tabela 4.1), o que se levantou nas entrevistas realizadas com os concessionários foi que: 1) de maneira geral os revendedores ainda não vêem a atividade como parte do negócio. Ela é necessária para que a venda do carro novo ocorra; 2) existe uma relação ambígua entre garagistas e concessionárias: a rede é fornecedora dos garagistas tanto m que se refere aos 
carros usados como aos carros novos. Os garagistas servem a rede nos momentos em que o revendedor, necessitando de giro, "queima" ou vende na "boca" o carro $0 \mathrm{Km}$.

Os sites de vendas de carros pela Internet são, na opinião dos respondentes, os que oferecem menor concorrência à rede. No Brasil, o formato de comércio eletrônico que está prevalecendo é o de prestador de serviços de informação, onde o consumidor pode comparar modelos e preços. Segundo os concessionários, o que está ocorrendo é que uma parcela considerável dos compradores (de 30 a $60 \%$ dos consumidores, segundo declarações dos revendedores) está consultando os sites para tomada de preço, tanto de carro novo como de usado, e para fazer simulação de financiamento e chegam nas concessionárias já com as informações. Segundo eles, isso tem reduzido muito a margem de negociação do revendedor local e alterado algumas práticas antigas de vendas.

Especificamente quanto às vendas diretas das montadoras pela Internet, a maioria das revendas se posicionou de forma positiva, alegando que é um bom negócio para elas e que não tem afetado de forma significativa o negócio da revenda. Há, no entanto, uma parcela considerável que acredita que no futuro as vendas diretas pela internet poderão mudar o papel da revenda na distribuição de veículos (tabela 4.17). No momento a participação dos revendedores no processo é grande e em quase todos os casos o negócio só se consolida na concessionária. A compra de um carro novo, envolve na maioria das vezes a negociação do carro usado, negociação de prazo de pagamento e financiamento que são atividades desempenhadas pelos revendedores. Além disso, a fórmula usada para reduzir o conflito entre montadoras e rede parece ter sido eficiente, que é o pagamento de uma comissão ao revendedor pela entrega do veículo (com a revisão) e o redirecionamento da demanda para o canal tradicional. Esses mecanismos têm sido apontados na literatura como fundamentais para regular o conflito advindo da introdução de canais diretos de distribuição pelos produtores (TSAY; AGRAWAL, 2004).

Há ainda fatores culturais de hábitos de compra do consumidor. Segundo pode-se levantar nas entrevistas com os concessionários, um aspecto importante é o tempo de espera: os consumidores não estão dispostos a esperar pelo produto. A exceção é o Celta, que é vendido pela Internet à pronta entrega. Outro aspecto importante é o que os concessionários designam por "fator confiança": o consumidor quer saber quem está vendendo o carro para ele e a quem 
deve reclamar quando for o caso. Além disso, um carro é um bem caro e o consumidor que ver o produto antes da compra.

Tabela 4.17- Visão dos concessionários sobre o comércio eletrônico de carros das montadoras.

Item

Uma ameaça à sobrevivência de rede

Uma prática que não tem afetado o negócio da revenda

Um bom negócio para a revenda hoje

Uma prática que pode alterar o papel da revenda na distribuição

Qualidade dos serviços e custos são variáveis importantes no gerenciamento dos serviços de assistência técnica (KOTLER, 2000); e estes estão se tornando importante na disputa por vantagens competitivas. A melhoria da qualidade dos serviços e a redução de custos estão entre as prioridades das revendas pesquisadas (gráfico 4.8).

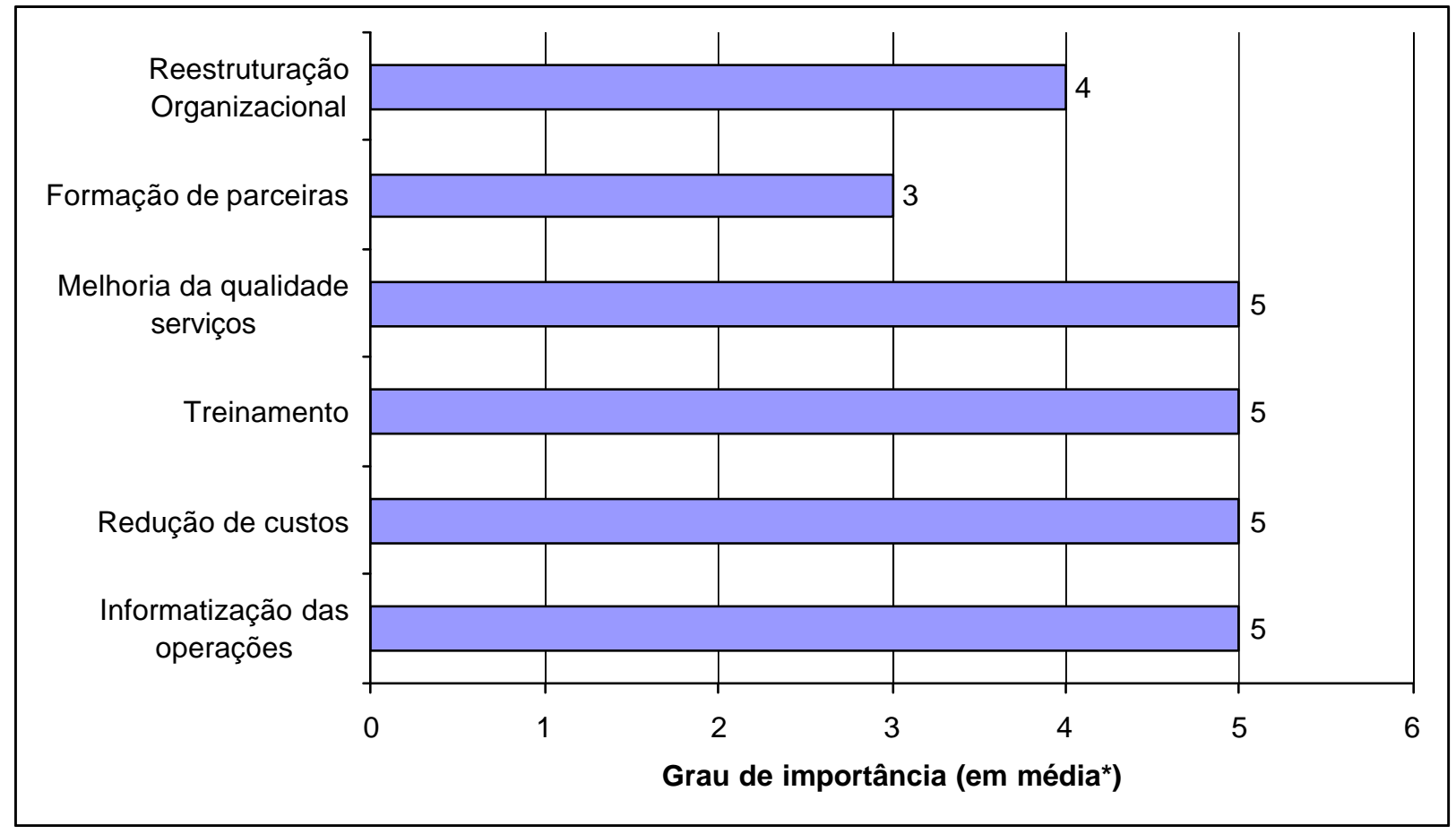

Gráfico 4.8 - Prioridades das revendas.

*Avaliação obtida segundo uma escala com valor máximo de 5, onde: 5 é extremamente importante e 1 sem importância. 
Outras prioridades são o treinamento e a informatização das operações. No geral, a estrutura das revendas é grande e a produtividade é baixa, em média tem-se um carro novo vendido por funcionário (ver item 4.2.1). Ganhos de escala podem ser alcançados com uso efetivo das tecnologias da informação e da capacitação dos funcionários.

A formação de parcerias que, segundo Narus e Anderson (1996), é importante para aumentar o nível de serviço e atender melhor o consumidor não foi considerado prioritário, sugerindo que os concessionários não a vêm como algo estratégico e importante para a redução de custos e melhoria do atendimento.

Com margens sendo achatadas na venda de carros novos, as concessionárias estão tendo que se dedicar a atividades dos serviços, peças de reposição e venda de carros usados. Qualidade dos serviços e nível de serviços, como o tempo de espera são variáveis importantes para a competitividade das concessionárias. Contudo, apesar das iniciativas de adoção de programas de qualidade, satisfação etc. parece que as revendas ainda não conseguem justificar seus preços através dos serviços oferecidos e têm dificuldade de manter o consumidor mesmo por um período de tempo que teoricamente teriam vantagens sobre os outros prestadores de serviços automotivos, devido por exemplo às dificuldades destes no acesso às tecnologias de diagnose, que seria o período de garantia dos veículos.

Conforme o proposto, neste capítulo foram apresentadas as análises dos resultados obtidos através das entrevistas com as associações de marcas e revendedores e do questionários enviado aos revendedores. Os dados corroboram as proposições desta pesquisa e permitem certas considerações que se encontram no capítulo seguinte.

\section{CONCLUSÃO}


Esse trabalho teve por objetivo analisar as mudanças que estão ocorrendo nos canais de distribuição de carros novos no Brasil, especificamente no que concerne à formação de novos formatos de negócio no varejo de automóveis novos e à relação com as montadoras.

O sistema de distribuição de carros novos baseado em redes de revendedores exclusivos de cada marca/montadora entrou na pauta da indústria automotiva na última década, devido ao aumento da concorrência e a ineficiência do sistema em atender as expectativas dos consumidores em termos de qualidade de serviços e preços.

Entre as propostas para um aumento da eficiência do setor, abordadas na literatura sobre distribuição de veículos nos Estados Unidos e Europa, pode-se destacar: a melhoria da imagem dos revendedores junto ao consumidor final; a melhoria no relacionamento entre revendedores e montadoras; e uma maior especialização dos revendedores através da desagregação de suas funções.

No Brasil, várias discussões sobre reestruturação das redes de distribuição e do formato de negócio da revenda estão em andamento desde o início dos anos 2000. A realização de um levantamento preliminar de dados junto a concessionárias brasileiras e a associações representativas do setor trouxe evidências de mudanças na forma como as concessionárias estão operando suas funções. A partir do quadro teórico que engloba canais de distribuição e distribuição de veículos e das observações iniciais de campo formularam-se três proposições que orientaram a pesquisa:

P1: As concessionárias de automóveis novos no Brasil estão se reestruturando, buscando terceirizar algumas de suas funções ou compartilhar recursos a fim de recuperarem suas margens e rentabilidade.

Existe uma tendência atual de especialização dos agentes dos canais de distribuição. A formação de parcerias entre distribuidores e outros prestadores de serviços especializados tende a aumentar a oferta de serviços nos canais distribuição. A literatura sobre distribuição de veículos sugere que uma especialização das revendas através da desagregação de suas funções traria vantagens em termos de ganhos de escala. 
Essa proposição pode ser confirmada pelos resultados apresentados na seção 4.2.2 deste trabalho, onde foram apresentas os serviços terceirizados pelas concessionárias e os resultados obtidos em termos de redução de custo, rapidez e melhoria da qualidade.

P2: Está havendo uma mudança no padrão de relacionamento entre montadora e rede de distribuição no sentido de construir relacionamentos mais cooperativos.

A literatura sobre canais de distribuição aponta que para cumprir os objetivos de satisfação e geração da demanda, um aspecto importante é o desenvolvimento de posturas mais cooperativas e de resolução rápida de conflitos entre distribuidores e produtores.

Essa proposição pode ser comprovada pelos resultados apresentados na seção 4.2.3, porém há ressalvas a serem feitas: há diferenças qualitativas entre as redes. A mudança é incipiente e é mais evidente nas montadoras novas. Aparecem elementos que são comumente citados na literatura como referência na construção de posturas mais colaborativas de relacionamento, como ênfase em treinamento, exclusividade territorial, redução do número de distribuidores.

P3: As concessionárias de automóveis novos no Brasil estão inovando através da adoção de novas práticas de gestão, da utilização de tecnologias da informação e ampliação dos serviços oferecidos aos clientes.

A literatura aponta uma tendência do varejo em geral de uso das tecnologias da informação para melhorar a produtividade e a oferta de serviços aos clientes.

Essa proposição pode ser comprovada pelos resultados da seção 4.2.4. Tem-se que a concessionárias estão fazendo uso de comércio eletrônico e informatizando seus principais processos bem como adotando programas de qualidade, satisfação e indicadores de desempenho e ampliando seus serviços aos clientes.

Dessa forma, podem-se elencar as seguintes conclusões: 
Levantou-se que, no Brasil, estão ocorrendo terceirizações nas atividades de assistência técnica e reparo, especialmente em funilaria e serviços rápidos (alinhamento, balanceamento, etc).

Essas terceirizações estão se refletindo em ganhos de qualidade, rapidez e redução de custos para os revendedores, aspectos que são importantes para manter posição competitiva no mercado. Pode-se, a princípio, dizer que esses resultados, pelo menos no que diz respeito aos aspectos investigados, se alinham com o que sugere a literatura quanto aos benefícios de uma desagregação das funções da revenda.

No entanto, esse fato caracteriza-se mais numa reação das revendas no sentido de adequarem a produção de serviços à demanda do que propriamente numa estratégia pró-ativa de negócio. A terceirização tem se dado pelos seguintes motivos: a) a maior especialização dos prestadores de serviço com melhor preço e qualidade e b) a ação das seguradoras de veículos que oferecem vantagens aos seus clientes que autorizam os serviços em reparadores independentes indicados por elas.

Trata-se, enfim, de um movimento do próprio varejo, que a princípio não está sob o controle das montadoras. A interferência delas no processo foi baixa e, à exceção dos serviços de oficina mecânica, não se alegou resistência declarada das montadoras.

Não se pode afirmar, ainda, que há uma grande difusão de terceirização, havendo a coexistência de dois formatos de negocio: o mais tradicional e esse mais "enxuto". No entanto, uma focalização das revendas nos serviços especializados de mecânica poderia ser benéfica: mais focalizadas na atividade, as revendas poderiam direcionar seus esforços e aumentar sua participação nesse mercado dominado atualmente pelas oficinas independentes. Poder-se-iam obter melhoria da qualidade dos serviços, com aumento da confiabilidade; maior rapidez na entrega dos serviços e redução de custos.

$\checkmark$ O sistema de redes de concessionárias está migrando para o modelo de franquia de negócio formatado, com padronização do atendimento, do processo de venda etc, seguindo uma tendência já observada no setor nos Estados Unidos. 
Isso indica: 1) uma ação das montadoras no sentido de melhorar o atendimento na rede; 2) um aumento de controle sobre a distribuição de produtos e serviços.

O potencial de conflito é grande uma vez que os revendedores foram empreendedores independentes com visão própria do negócio durante décadas e, conseqüentemente, deve haver uma resistência relativa à essa imposição de procedimentos próprios do sistema de franquia de negócios formatado.

Por outro lado, seguindo uma tendência observada nos Estados Unidos e na Europa, as montadoras estão buscando restringir o número de revendedores e, ao mesmo tempo, agindo no sentido de orientar seus revendedores a respeitarem as áreas de atuação. Em alguns casos existem políticas sendo definidas pelas montadoras para garantir exclusividade territorial, fato este que deve ter efeito na lucratividade das revendas e reduzir o nível de conflito horizontal nas redes de distribuição.

Observa-se também que as montadoras estão dando suporte em áreas de gestão e investindo em treinamento da rede. Já existem redes no Brasil em que a ênfase em treinamento é grande. É provável que isso se intensifique na medida que o sistema de concessionárias se aproxime do de franquias de negócio formatado, pois é característico desse sistema a assistência técnica e operacional contínuas.

Além disso, está havendo mudanças num dos pontos de maior atrito entre revendedores e montadoras que é o sistema de cotas: o sistema está mais flexível e as concessionárias estão recebendo os produtos em maior conformidade com o solicitado.

Ainda com relação à aproximação das redes ao modelo de franquia de negócio formatado, a marca é o principal ativo específico em questão. Assim, as exigências das montadoras na padronização de certos processos têm por objetivo o fortalecimento da marca. O princípio é que a falta de padronização dos elementos que estão mais diretamente associados à imagem da marca pode acarretar em sua depreciação e prejuízos para toda a rede.

O sistema é uma alternativa à integração vertical, porém mais rígida que o formato de franquia de segunda geração, que ainda caracteriza os canais de distribuição de veículos 
novos no Brasil. Para garantir essa padronização, é necessário um eficiente gerenciamento a jusante.

As montadoras passaram a controlar aspectos, como processo de vendas, atendimento etc, que a priori não estavam sob seu controle, no sentido de garantir que certos serviços sejam fornecidos de forma regular em termos de qualidade.

As estratégias de coordenação e controle das atividades de distribuição que estão sendo utilizados pelas montadoras não se constituíram em objeto de estudo desta tese e são aspectos a serem elucidados em outros estudos. Porém, é de se esperar que as montadoras estejam utilizando mecanismos de coordenação diferenciados: mais rígidos para os serviços que elas julguem mais diretamente associados à marca., e outros, mais tênues, para os demais. É o caso por exemplo da resistência das montadoras quanto a uma terceirização dos serviços de oficina.

No caso das terceirizações, esse fato pode até vir a alterar a forma como as concessionárias estão coordenando as atividades com os prestadores de serviço, como por exemplo, a adoção de contratos formais que garantam o padrão de qualidade exigido, ou as próprias montadoras podem assumir a coordenação dessas atividades, credenciando prestadores de serviços para a rede. Porém, trata-se de uma hipótese que carece de investigação mais detalhada.

O que fica evidente é que as montadoras estão começando a entender que seus produtos incluem serviços, e que estes são importantes para a imagem de suas marcas e as montadoras estão tomando a iniciativa de direcionar suas redes para os serviços.

Ressalta-se, no entanto, que há diferenças grandes entre as montadoras quando à padronização dos processos de produção de serviços. Ela é mais evidente entre as novas marcas; no entanto, as grandes montadoras também começam a agir nesse sentido.

$\checkmark$ Observou-se, de modo geral, o uso de sistemas de comércio eletrônico e a informatização de boa parte dos principais processos da revenda, seguindo uma tendência já apontada na literatura. Ressalva seja feita ao processo de obtenção de informação sobre as necessidades dos clientes, o que sugere que há pouca informação sistematizada e 
disponível sobre elas, aspecto que deve limitar a abrangência dos programas de qualidade, satisfação e fidelização nas revendas.

$\checkmark$ Verificou-se a ampliação do mix de serviços oferecidos aos clientes pelas revendas.

Essa é uma tendência observada entre as revendas americanas e européias. Os dados levantados evidenciam um certo padrão nas revendas pesquisadas, como licenciamento, vendas de seguro, instalação de acessórios. Uma das características dos serviços é que eles são facilmente imitados e, portanto, perdem logo seu caráter de novidade e efeito de diferenciação. Assim, é preciso esforço das revendas em inovar continuamente esse aspecto.

Quanto às práticas de gestão, ocorre a adoção de programas de qualidade, satisfação dos clientes e indicadores de desempenho.

No entanto, ainda estão dando pouca atenção aos programas de fidelização e de capacitação dos recursos humanos. Os primeiros são ferramentas importantes para as revendas estabelecerem um processo de marketing de relacionamento eficiente que permita explorar o potencial de seus clientes. Os segundos são relevantes porque a capacitação dos recursos humanos é a base para a adoção bem sucedida de novas tecnologias e práticas de gestão e também porque as revendas são empresas prestadoras de serviços e é inerente a esses sistemas a presença do consumidor no processo de produção de serviços, o que requer que habilidades e competências específicas sejam adquiridas: saber lidar com o atendimento é questão importante para satisfação dos clientes.

Falta assim, uma visão mais estratégica de serviços para os revendedores e capacidade de gestão para alinhar devidamente essas várias iniciativas (tecnologia, programa de qualidade etc).

Por exemplo, dever-se-ia usar a infraestrutura em tecnologias de informação, como CRM, sistemas de comércio eletrônico entre outros, para estabelecer um relacionamento mais próximo com os seus clientes desenvolvendo programas de fidelização e novos serviços que atendam e criem novas demandas. 
Seria possível também desenvolver estratégias mais agressivas de serviços e políticas de comercialização de peças para aumentar a participação das concessionárias em mercados hoje no Brasil dominados por outros atores, como as oficinas independentes. Comparativamente com as concessionárias americanas e européias, onde peças e serviços representam a maior fonte de ganhos das revendas, no Brasil os ganhos com essas atividades é baixo.

Uma variável importante dentro das análises sobre mudanças na distribuição de veículos é a legislação que regula as relações entre montadoras e distribuidores. No Brasil, não há até o momento previsão de mudanças na legislação, como a que está ocorrendo na Europa, obrigando as montadoras a reverem suas regras de distribuição. Aqui, a legislação é bastante favorável às montadoras, porém ela garante alguns direitos aos distribuidores. Mudanças mais drásticas, como a venda de carros novos através de canais de menor custo como supermercados, locadoras etc. precisam ser acordadas entre as entidades de representativas dos distribuidores e montadoras, como foi o caso das vendas diretas pela Internet. No entanto, ela permite muitas ações das montadoras sobre as redes de distribuição, como é o caso do aumento da exigência e de controle que as montadoras estão impondo sobre as redes e sobre seus processos de produção de serviço.

Alguns pontos levantados nesta pesquisa podem servir para reflexões das concessionárias e de suas entidades de representação quanto ao formato do negócio, tão discutido no início dessa década, e sobre as necessidades de preparação dos concessionários para se ajustarem às novas condições de competição do mercado brasileiro.

De um modo geral, os resultados encontrados validam as tendências já apontadas na literatura sobre canais de distribuição e distribuição de veículos. Por outro lado, as contribuições que esta pesquisa oferece à literatura referem-se aos efetivos ganhos que uma especialização da revenda pode trazer em termos de custos e qualidade para a melhoria do sistema atual de distribuição, baseado em redes de franquias/concessionárias exclusivas. Merece ser realçado também a migração do sistema atual para um modelo que se aproxima ao que se denomina franquia de negócio formatado, fato que já ocorreu em outros setores como o de alimentos. E por fim, destaca-se uma sistematização da literatura sobre distribuição de veículos. 


\subsection{Sugestões para pesquisas posteriores}

Devido à natureza do método escolhido, um survey complementado com entrevistas, não foi possível investigar em profundidade certos fenômenos, como o processo de formação de novos arranjos de negócio e de adoção de novas práticas de gestão, ou como conhecer os detalhes da relação com as montadoras.

Ainda existem questões que merecem pesquisas específicas e podem ser esclarecidas em trabalhos futuros partindo dos seguintes pontos:

$\checkmark$ as reais dimensões do abrandamento do sistema de cotas e seus reflexos no canal e na produção;

$\checkmark$ as mudanças nas práticas de gestão do canal;

$\checkmark$ o uso das novas tecnologias de informação no canal de distribuição;

$\checkmark$ uma análise mais qualitativa das mudanças no relacionamento, explicitando em que níveis elas estão ocorrendo e como elas estão se processando.

Seria interessante a condução de estudos de caso considerando o par montadora/rede, abordando os aspectos acima citados. Outros aportes teóricos poderiam ser usados para tratar o tema como os fundamentos da nova economia institucional, focalizando a questão dos contratos e os mecanismos de coordenação. 


\section{REFERÊNCIAS BIBLIOGRÁFICAS}

ALBERTIN, A. L. Comércio eletrônico: aspectos e contribuições de sua aplicação. 2 ed. São Paulo : Atlas, 2000. 242 p.

ALCÂNTARA, R. L. C. A gestão estratégica dos canais de distribuição: um exame da evolução e do atual estágio do relacionamento entre o atacado de entrega e a indústria. 1997. Tese (Doutorado) - Fundação Getúlio Vargas, São Paulo, 1997.

ALMEIDA, P. H. Futuro do marketing de distribuição na indústria automobilística. Nexos Econômicos, v. II, n. I, p. 143- 152, out., 2000.

ALVARENGA, S. O acesso dos reparadores às montadoras. AE SetorialAutomotivo. Agencia Estado, junho, 2003.

ANDERSON, E.; DAY, G.S.; RANGAN, V.K. Strategic channel design. Sloan Management Review, v. 38, n. 4, p. 59-69, summer, 1997.

ANDERSON, E.; WEITZ, B. The use of pledges to build and sustain commitment in distribution channels. Journal of Marketing Research, v. 29, n. 1, p. 18-34, Fev. 1992.

ANSERSON, E. The salesperson as outside agent or employee: a transactional cost analysis. Marketing Science, v. 4, 234-253, 1985.

ARBIX, G.; VEIGA, J. P. C A distribuição de veículos sobre fogo cruzado: em busca de um novo equilíbrio de poder no setor automotivo. Artigos e Estudos. Disponível em: <http://www.fenabrave.org.br>. Acesso em 22. out. 2001.

ASSOCIAÇÕES de marcas apontam tendências para o setor. Dealer On-Line, n. 34, jan. 2002: no ar desde set. 2000. Disponível em: 〈http://www.dealeronline.com.br〉. Acesso em: 26 jan. 2002.

BARRENECHEA, M. J. e- Business ou fora do negócio: a estratégia da Oracle para lucrar na nova economia. São Paulo : Makron Books, 2001.

BARRETO FILHO, J. E. P. Resistir à tentação. Disponível em: 〈http://fenabrave.org.br/localizar.asp> Acesso em: 16 abr. 2002a.

Ford vende suas concessionárias. Disponível em: <http://fenabrave.org.br/localizar.asp> Acesso em: 15 jan. 2002b.

BLOCK exemption: novas regras do setor de distribuição europeu começam em outubro. Disponívelem: <http:// www.fenabrave.org.br/localizar.asp> Acesso em: 01 jun. 2002.

BOHMAN, E.; ROSENBERG, J.; STENBRIK, P. Overhauling european auto distribution. The Mckinsey Quarterly, n. 1, p. 134-142, 2003.

BOWERSOX, D. J.; COOPER, M.B. Strategic marketing channel management. New York: McCraw-Hill, 1992. 
BRADSHER, K. Car dealers learn to tame the web. The New York Times. New York, 18 dez. 2000. Business/Financial. Section C, p.16.

BRASIL. Lei n. 6.729, de 28 de novembro de 1979. Dispõe sobre a concessão comercial entre produtores e distribuidores de veículos automotores de via terrestre.

BUZZAVO, L.; VOLPATO, G. Car distribution in Europe: between vertical agreements and customer satisfaction. COCKEAS RESEARCH NETWORK, Berlin meeting, nov. 2001.

CARLZON, J. A hora da verdade. 9 ed. Rio de Janeiro : Cop. 1993. 120 p.

CHANARON, J. J.; JULLIEN, B. The production, and repair of automobiles: new relationships and new competencies. In : LUNG, Y. et al. Coping with variety: flexible productive systems for product variety in the auto industry. Hampshire : Ashpate, 1999. p. 335-363.

CHURCHILL, G.; PETER, J. P. Marketing: criando valor para os clientes. São Paulo : Saraiva, 2000.

CONCESSIONÁRIA enxuta: guia prático. São Paulo: Fenabrave, 2002

CONTROLE: um aliado para a sobrevivência das concessionárias. Dealer On-Line, n. 29, abr. 2001 : no ar desde set. 2000. Disponível em: 〈http://www.dealeronline.com.br〉. Acesso em: 12 nov. 2001.

CRIATIVIDADE e serviços diferenciados garantem a fidelização dos clientes. Dealer on Line, n. 29, abr. 2001: no ar desde set. 2000. Disponível em: <http://www.dealeronline.com.br>. Acesso em: 10 maio 2001.

DIAS, S. R. Estratégia e canais de distribuição. São Paulo : Atlas, 1993.

DONEY, P. M; CANNON, J. P. An examination of the nature of trust in buyer-seller relationships. Journal of Marketing. v. 61, n. 2, p. 35-51, Apr 1997.

EALEY, L. A.; BERMÚDEZ, L. T. The automotive industry: a 30,000 mile checkup. The Mckinsey Quarterly, n. 1, p. 72-79, 2000.

FENABRAVE inicia certificação de qualidade de usados. Disponível em: <http://www.fenabrave.org.br/localizar.asp>. Acesso em: 04 mar 2001.

FERREIRA, E. J. Publicação eletrônica [entrevista]. Disponível em 〈http://www.camarae.net/interna.asp?tipo=3\&valor=34\&pag=2> . Acesso em: 20 nov 2003.

FITES, D. Make your dealers your partners. Harvard Business Review, v. 74, n. 2, p. 84-95, Mar./Apr., 1996.

FOURNIER; DOBSCHA, S.; MICK, D. Preventing the premature death of relationship marketing. Harvard Business Review, v. 76, n. 1, p. 42-51, Jan./Feb. 1998. 
FREITAS, H. et al. O método de pesquisa survey. Revista de Administração, v. 35, n. 3, p. 105-112, jul./set.. 2000.

FUSÕES começam a criar as revendas gigantes. O Globo, Rio de Janeiro, 26 mar. 2000. Caderno de Economia.

GIANESI, I. N., CORRÊA, H. L. Administração estratégica de serviços. São Paulo : Atlas, 1994.

GRÖNROOS, C. Marketing: gerenciamento e serviços. 4 ed. Rio de Janeiro : Campus, 1995.

HANDFIELD, R.B.; NICHOLS, Jr., E.L. Introduction to supply chain management. New Jersey : Prentice-Hall, 1999. 183p.

HATZFELD, N. Changes in distribution; reconstructing the downstream domain of the automobile industry. La Lettre du Gerpisa, n. 121, p. 3-4, mars 1998.

HESKETT, J.L.; SASSER, W.E; SCHLESINGER, L.A. The service profit chain: how leading companies link profit and growth to loyalty, satisfaction and value. New York: The Free Press, 1997.

HESSEL, R.; VILARDAGA, V. Grande reviravolta no varejo de automóveis. Gazeta Mercantil, São Paulo, 22 jun.2000. Caderno C, p. 1.

HIRSH, E. R. et al. Changing channels in the automotive industry: the future of automotive marketing and distribution. Booz-Allen \& Hamilton Business + Strategy, first quarter, 1999. Disponível em: <http://www.bah.com>. Acesso em: 04 fev.2004.

HOFFMEISTER, M. Multi-franchising in US car distribution. International Car Distribution Programme, 1995. (Research Paper 13/95).

ÍNDICE de varejo totaliza $\mathrm{R} \$ 5,2$ bilhões no Brasil em 2003. Disponível em: <http://econsultingcorp.com.br/vol/index_2003.htm〉. Acesso em 2 fev. 2004.

INFORMATIVO FENABRAVE, v. 2, n. 35, jan. 2004. Disponível em: $<$ http://www.tela.com.br/dadosmercado/index.asp?codItem=1\&ws=f $>$. Acesso em: 15 jan. 2004.

INFORMATIVO FENABRAVE, v.1, n. 8, jan. 2003. Disponível em: $<$ http://www.tela.com.br/dadosmercado/index.asp?codItem=1\&ws=f $>$. Acesso em: 15 jan. 2004.

KAPLAN, R.; NORTON, D.P. The balanced scorecard: translating strategy into action. Boston : Harvard Business School Press, 1996. 322 p.

KELLOGG, D.L.; NIE, W. A framework for strategic service management. Journal of Operations Management, v.13, p.323-337, 1995.

KIDDER, L.H.; JUDD, C. M. Research methods in social relations. 5. ed. New York : Holt, Rinehart and Winston, CBS College Publishing, 1986. 
KNUPFER, S. M.; RICHMOND, R. K,; ARK, J. D. V. Making the most of US auto distribution. The Mckinsey Quarterly, n. 1, p. 142-147, 2003.

KOTLER, P. Administração de marketing: análise, planejamento, implementação e controle. São Paulo : Atlas, 1996.

Administração de marketing : a edição do novo milênio. 10 ed. São Paulo : Prentice Hall, 2000. 764 p.

KUMAR, N. The power of trust in manufacturer-retailer relationships. Harvard Business Review, v. 74, n. 6, p. 92-106, nov./dec. 1996.

LAFONTAINE, F. Agency theory and franchising: some empirical results. Rand Journal of economics, v. 23, n. 2, 1992.

LAS CASAS, L. A. Marketing de varejo. 3 ed. São Paulo: Atlas, 2004.

LAZZARINI, S. G. Estudos de caso: aplicabilidade e limitações do método para fins de pesquisa. Economia \& Empresa. São Paulo, v. 2, n. 4, p. 12-26, out./dez. 1995.

MAIA, H. Distribuidores versus montadoras. Gazeta Mercantil, São Paulo, 17 a 19 nov. 2000. Caderno A, p. 2.

MARUCA, R., F. Retailing: confronting the challenges that face bricks-and-mortar stores. Harvard Business Review, v. 77, n. 4, p. 159-168, Jul./Aug. 1999.

MENDEZ, M.; LEHNISCH, J. P. Como fazer da franquia um bom negócio. São Paulo : Nobel, 1991.

MERCER, G. Unbundled distribution: the next competitive weapon? In : THRIVING on change in the automotive industry. London : Mckinsey \& Company, Inc., 1994. p. 149-77. (The Economist Intelligence Unit Motor Business Series).

The automotive retailing revolution: new dawn or end game? In: SUCCEEDING in the nest automotive century. London : Mckinsey \& Company, Inc., 1999. p. 131-149. (The Economist Intelligence Unit Motor Business Series).

A new way to sell cars. The Mckinsey Quarterly, n. 1, p. 132-4, 2003.

MORAES, S. Consumidor prefere concessionárias à web. Gazeta Mercantil, São Paulo, 30 ago. 2000. Caderno C, p. 1.

MORGAN, R. M; HUNT, S.D. The commitment-trust theory of relationship marketing. Journal of Marketing, v. 58, n. 3, Jul 1994.

NADA data 2003: economic impact of America's new-car and new truck dealers. NADA' S AutoExec 2003. (Relatório). Disponível em: 
〈http://www.nada.org/Content/NavigationMenu/Newsroom/NADAData/NADA_Data.htm> Acesso em: 10 dez. 2003.

NARUS, J.; ANDERSON, J. C. Rethinking distribution: adaptive channels. Harvard Business Review, v. 74, n. 4, p. 112-120, Jul./Aug., 1996.

NEVES, M. F. Um modelo para planejamento de canais de distribuição no setor de alimento. 1999. Tese (Doutorado) - Faculdade de Economia, Administração e Contabilidade da USP, São Paulo, 1999.

NEVES, M. F.; ZUURBIER, P.; CAMPOMAR, M. C. A model for the distribution channels planning process. The Journal of Business \& Industrial Marketing, v. 16, n. 6/7, p. 518539, 2001.

NISHIMURA, K. G.; MORITA, M. Information technology and automotive distribution: a comparative study of Japan and the USA. Int. J. Automotive Technology an Management, v. 2, n.2, p. 206-235, 2002.

NOVOS formatos de estruturação da rede: entre fusões e operações consolidadas. Dealer OnLine, n. 31, ago. 2001 : no ar desde set. 2000. Disponível em: <http://www.dealeronline.com.br $>$. Acesso em: 05 set. 2001.

O'CONNEL, B. B2B.com cashing on the business-to-business e-commerce bonanza. Holbrook : Adams Media Corp., 2000.

OLIVEIRA, L. O medo do e-commerce. Gazeta Mercantil, São Paulo, 22 ago. 2000. Caderno C, p. 8.

OPPENHEIM, A. N. Questionnaire design, interviewing and attitude measurement. New York : Continuum, 2001.

PERSPECTIVAS para o setor de autopeças para os próximos anos. Autopeças, v. XI, n. 80, p. 63- 64, Abril 2001.

PORTER, M. E. Strategy and the internet. Harvard Business Review, v. 79 n. 2 p. 63-78 mar./apr. 2001.

PÓS-VENDAS: um canal para aumentar a rentabilidade. Disponível em: <http://www.fenabrave.org.br/localizar.asp> . Acesso em: 05 ago. 2001.

PROJETO Peça Genérica é lançado na Rede Vida. Disponível em: <http://www.fenabrave.org.br/localizar.asp> . Acesso em: 08 nov 2002.

REICHHELD, F.; SASSER, W. E. Zero defections: quality comes to services. Harvard Business Review, v. 68, n. 5, p. 42-51, Sept./Oct. 1990.

RICHARDSON, R. J. et al. Pesquisa social: métodos e técnicas. São Paulo : Atlas, 1985. 
RIZZI, P. M. Franchising: como adquirir uma franquia. São Paulo : SEBRAE-SP, 1996. (Manual prático)

ROCHA, T.; VELOSO, A. A hora da recompensa: como obter sucesso através dos programas de fidelização. São Paulo : Cobra Editora, 1999. 184 p.

ROSA, T. Jeitinho nunca mais. Mais Automotive, v. 7, maio, 2004.

ROSEMBLOON, B. Marketing channels. 6 ed. New York : Dryden Press, 1999. 688 p.

SALERNO, M. S. A indústria automobilística na virada do século. In: ARBIX, G. ; ZILBOVICIUS, M., eds.. De JK a FHC, a reinvenção dos carros. São Paulo : Scritta, 1997.

SAPPINGTON, D. E. M. Incentives in principal -agent relationships. Journal of Economic Perspectives, p. 45-66, Spring, 1991.

SASSER, W. E.; OLSEN, R. P.; WYCKOFF, D. D. Management of service operation. Allyn and Bacon, 1978.

SELLTIZ, C. et al. Métodos de pesquisa nas relações sociais. São Paulo : Editora Pedagógica e Universitária Ltda, 1974.

SILVA, A. L; ALCÂNTARA, R. C. Mudanças nos relacionamentos e estratégias para melhor coordenação da cadeia de suprimentos. Revista de Administração, v. 36, n. 3, p. 49-58, jul./set. 2001.

SILVA, C. Carros são vendidos pela internet a preço menor. O Estado de São Paulo, São Paulo, 19 set. 2000 , Caderno B, p.7.

SIMSEK, Z. Sample surveys via electronic mail: a comprehensive perspective. Revista de Administração de Empresas, v. 39, n. 1, p. 77-83, jan,/mar. 1999.

STAIR, R. Princípios de sistemas de informação: uma abordagem gerencial. Rio de Janeiro: Livros Técnicos e Científicos, 1998. 451 p.

STERN, L. W.; EL-ANSARY, A; COUGHLAN, A. T. Marketing channels. 5 ed. New Jersey : Prentice Hall, 1996.

UNIVERSIDADE do concessionário do futuro oferece ensino corporativo para profissionais da rede. Disponível em: 〈http://www2.fenabrave.org.br/notivias/docs/48.htm〉 Acesso em: 11 set. 2001.

URDAN, A. T.; ZUÑIGA, M. K. H. Satisfação com assistência e lealdade ao fabricante no ramo automobilístico. Revista de Administração de Empresas, v. 41, n. 3, p. 31-41, jul./set. 2001.

VILARGADA, V. O contra-ataque da Ford para recuperar o mercado. Gazeta Mercantil, São Paulo, 10 mar. 1999. Caderno C, p. 6. 
VISÃO do setor de distribuição europeu depois da adoção da nova regulamentação. Disponível em: <http://www.fenabrave.org.br/noticias/1259.htm>. Acesso em: 29. set 2003.

WILLIAMSON, O. Mechanisms of Governance. New York : Oxford University Press, 1996.

WISE, R.; BOUMGARTNER, P. Go downstream: the new profit imperative in manufacturing. Harvard Business Review, v. 77, n. 5, p. 133-141, Sep./Oct., 1999.

WOMACK, J. P.;JONES, D. T.; ROOS, D. A máquina de mudou o mundo. 11 ed. Rio de Janeiro : Campus, 1992.

YIN, R. K. Case study research: design and methods. 2.ed. Newbury Park : Sage Publications, 1994.

ZEITHAML, V.; PARASURAMAN, A. BERRY, L. Delivering quality service: balancing customer perception and expectations. New York: The Free Press, 1990.

ZILBER, S. N. Fatores críticos para o desempenho e implantação de e-business por empresas tradicionais. 2002. Tese (Doutorado) Faculdade de Economia, Administração e Contabilidade, Universidade de São Paulo, São Paulo, 2002.

\section{Sites pesquisados}

FENABRAVE. Disponível em: $<\underline{\text { http://www.fenabrave.org.br }>}$

DEALER ON LINE. Disponível em: $<\underline{\text { http://www.dealeronline.com.br }>}$

NADA. Disponível em: < http://www.nada.org> 


\section{ANEXO 1 - Roteiros de entrevistas}

\section{A) Roteiro de Entrevista - FENABRAVE e Associações de Marcas}

- Sobre a FENABRAVE a as Associações de Marcas

1) Como é composta a FENABRAVE?

2) Como são constituídas as Associações de Marcas?

3) Como se processam as negociações com as montadoras?

4) O que compete a Fenabrave e o que compete às Associações de Marcas?

- Sobre a situação das redes de concessionárias

5) Qual é efetivamente o negócio da revenda? No que ela ganha: vendas de carros novos, vendas de carros usados, serviços de manutenção, reposição de peças?

6) Qual é atualmente a função básica da rede de concessionárias: criar ou suprir a demanda?

7) Em termos de desempenho, o que é efetivamente cobrado das concessionárias?

8) Na sua opinião, o que influencia mais na "fidelidade" dos clientes: preço, rapidez de atendimento, qualidade do serviço, nível de serviço?

9) Fala-se em mudanças na estrutura de distribuição de veículos novos. Quais são as principias mudanças que estão ocorrendo na distribuição de veículos no Brasil (concentração no varejo, multimarcas, expansão dos canais, especialização dos serviços no canal)? (Quais são os principais fatores que estão pressionando para que haja mudança?

10) Em relação à estrutura de distribuição, pode-se dizer que existam diferenças entre as montadoras estabelecidas há décadas no país e as que estão se instalando agora?

11) Existem diferenças contratuais significativas entre as montadoras e suas redes de concessionárias? Há diferenças substanciais entre nos contratos das montadoras estabelecidas há décadas no país e as que estão se instalando agora?

12) Estão ocorrendo modificações nas atividades administrativas e/ou operacionais na rede? Quais? De quem tem partido essas alterações? Existiram, ou vão existir , investimentos em recursos físicos e de pessoal? Quais são os principais concorrentes das redes de concessionárias? Qual o impacto de cada um deles no canal? As montadoras também são vistas atualmente como concorrentes?

13) Qual é a principal estratégia adotada pelas redes de concessionárias?

14) Qual tem sido a principal estratégia adotadas pelas montadoras?

15) Houve alteração na forma de relacionamento da rede de concessionárias com as montadoras?

16) Como efetivamente têm se processado as vendas de carros novos pela Internet (B2C)? Qual tem sido efetivamente o papel das concessionárias nesse processo?

17) Quais seriam os impactos da adoção de tecnologias da informação no canal de distribuição (desde o uso da tecnologia para a previsão de demanda até o B2C)? Seriam positivos ou negativos? Por quê?

18) No Brasil existe lei específica que rege as relações entre montadoras e revendedores. Quais são os limites dessa lei? Quais pontos beneficiam a rede de revendas? Quais pontos são favoráveis às montadoras 
19) Há algum movimento por parte dos revendedores (ou montadoras) no sentido de uma revisão dessa lei, em função das alterações de mercado, da entrada de novas tecnologias, mudança de comportamento do consumidor, etc?

20) Na sua opinião, quais são as questões fundamentais em relação à distribuição de veículos novos no Brasil?

21) Nesse contexto, é possível a sobrevivência das revendas enquanto membros do canal de distribuição? Como?

22) Como os revendedores têm se mobilizado (atuado, organizado) diante desse novo cenário? Qual tem sido o papel da FENABRAVE e das Associações de Marcas?

- Custos

23) Como são compostos os custos de distribuição?

24) Quanto dos custos totais do veículo corresponde o custo de distribuição? 


\section{B) Roteiro de Entrevista - Concessionárias}

- Características gerais

1) Dados Gerais:

- Nome da empresa

- Número de lojas atualmente. Há perspectiva de aumentar do número de lojas num futuro próximo?

- Número de funcionários

- Área de geográfica de atuação

- Número de carros novos comercializados por mês

- Número de atendimento na oficina

- Negócios associados (locação, garagem)

- Possui certificação? Quais

2) Contratos:

- Período de vigência contratual

- Quais fatores podem levar à rescisão contratual?

- É permitido que proprietários de concessionárias possuam também concessionárias de outras marcas?

3) Como se realiza o processo de seleção e treinamento dos revendedores?

- Exige experiência no ramo, formação profissional, capital disponível, dedicação exclusiva

- Quem arca com os custos de instalação (área, construção, equipamentos, publicidade)

- Quais os treinamentos dados os concessionários pela montadora no início do negócio?

- Há critério para estabelecer limites de atuação? Como são determinados?

- Funcionamento da concessionária

4) Quais atividades são desempenhadas pela concessionária? Venda de carros novos, compra e venda de carros usados, reposição de peças, assistência técnica, financiamento de veículos?

- Caso essas funções não sejam desempenhadas pela própria revenda, como elas são executadas?

- Por parceiras? Essas parceiras são regidas por contratos formais? Qual o período de vigência desses contratos? Quais os fatores que podem levar a uma quebra contratual? Já houve alguma quebra?

- Esses contratos são estabelecidos pela revenda ou pela montadora? Quais os critérios de seleção?

5) Como se dá o processo de venda de carros novos? Há carros para pronta entrega? É possível vendas diretas da montadora para o cliente final? Como elas ocorrem? Se não, há intenção da montadora em implantá-la num futuro próximo?

6) Como ocorre o processo de compra de carros novos? A montadora impõe cotas para os concessionários? São necessários altos investimentos em estoques? Qual é o tempo mínimo de pedidos? Como os valores são negociados?

7) Como funciona a oficina? Atende somente carro da marca ou é multimarcas? A funilaria é também mulitmarcas?

Que tipos de certificações são exigidas? (ASE, IQAINMETRO) 
8) A montadora impõe uma quota de peças de reposição que a revenda deve comprar da própria montadora?

- Estratégia e Ambiente

9) Rentabilidade: qual é efetivamente o negócio da revenda? No que ela ganha: vendas de carros novos ou serviços? É possível ter uma avaliação da rentabilidade de cada função desempenhada pela revenda?

10) O objetivo é atender a demanda ou criar demanda? Quais as ações que estão sendo tomadas?

11) Quais são os principais concorrentes? Quais são os potenciais concorrentes? A montadora é vista como um dos principais concorrentes? Carro novos na boca?

12) Qual é a estratégia competitiva da rede de concessionárias? Buscar novos serviços, por exemplo?

- Os serviços são desenvolvidos pela revenda ou pela montadora?

13) Qual é a estratégia competitiva da montadora? Grandes revendas ou pequenas revendas? Tem intenção de atuar em frentes tradicionalmente reservadas aos revendedores? Há preocupação com a padronização do atendimento da rede, na aparência da loja, na padronização dos processos e serviços?

14) Para reduzir custos, a revenda pretende fazer parte de alguma cooperativa

- Avaliação

15) Em termos de desempenho, o que é efetivamente cobrado das concessionárias?

16) Como vocês medem o nível de serviço recebido da montadora e o fornecido pela concessionária?

17) Quais dos seguintes fatores é mais importante para a fidelização do cliente: preço, disponibilidade do produto, rapidez na entrega, qualidade de produtos, outros atributos)

18) Sobre disponibilidade de produtos qual tem sido a estratégia: atender a demanda do cliente, ou criar demanda? Como isso é feito?

- Sobre o uso de novas tecnologias

19) A concessionária faz uso intensivo de tecnologias de informação? Em que áreas elas são mais utilizadas (compras, vendas, logística, financeiro, etc)? A revenda tem site? Que tipos de serviços ela vai oferecer no site?Quais são os principais impactos do uso da tecnologia no canal de distribuição?

20) A montadora tem imposto a adoção da tecnologia?

21) Os investimentos em tecnologia são realizados somente pela empresa ou junto com a montadora?

- Mudanças que ocorreram ou estão ocorrendo na distribuição

22) Quais são os fatores que estão afetando o negócio da concessionária ?

23)Está havendo mudança na forma de relacionamento entre a concessionária e a montadora? Como? Em que aspectos? Quais os objetivos dessa mudança? Como você classificaria essa forma de relacionamento?

24) Houve alterações em atividades administrativas e/ou operacionais? Quais? Como? Quem disponibilizará os recursos necessários (físicos e de pessoal) para essas alterações: montadora e/ou revenda? 
25)As atividades de marketing realizadas para criar demanda são realizadas sozinhas ou em conjunto com a montadora?

26)A revenda tem aderido aos programas desenvolvidos pela Fenabrave como a certificação de usados, Universidade do concessionários, implantação do CRM? Qual é a sua avaliação sobre esses programas?

27) A montadora tem imposto programas à revenda? Quais?

- Estrutura

28) Como está estruturada a distribuição (Regionais, escritórios, centros de distribuição)

- Custos

29) Como são compostos os custos de distribuição? 


\section{ANEXO 2 - Questionário \\ Pesquisa sobre a Reestruturação dos Canais de Distribuição de Veículos Novos no Brasil}

Prezado(a) Senhor(a):

Como aluna do doutorado da Escola Politécnica/USP, desenvolvo uma tese de doutorado pesquisando a distribuição de veículos novos no Brasil, cujo objetivo é compreender melhor esse setor. Especificamente procura-se identificar as inovações que estão ocorrendo em termos de formação de parcerias, relacionamento com as montadoras, adoção das tecnologias da informação além de outras práticas de gestão.

A fim de dar continuidade a esse trabalho e coletar os dados necessários, elaborourse o questionário em anexo, que está sendo enviado à uma amostra de concessionárias das redes de distribuição das principais montadoras do país. Sua empresa foi selecionada para fazer parte desta pesquisa. Assim, diante da necessidade da colaboração de sua empresa para o levantamento de dados da pesquisa, solicitamos a sua atenção e colaboração para o preenchimento do referido questionário.

O preenchimento deve ser feito no próprio documento e o retorno do questionário deverá ser por e-mail. Com a análise do conjunto das respostas pretendemos ter uma visão das ações realizadas pelas concessionárias no sentido de superarem os problemas devidos às novas condições de mercado.

Esclarecemos que se trata de uma pesquisa científica. Dessa forma, os dados obtidos serão tratados de forma agregada. Não serão divulgados o no me do respondente, nem a razão social da empresa e não serão feitas associações de informações que permitam a identificação da empresa. Informamos também que, concluída a pesquisa, estaremos disponibilizando os resultados a todos os participantes.

Colocamo-nos à disposição para discutir a pesquisa e esclarecer quaisquer dúvidas que possam existir. As dúvidas poderão ser esclarecidas com Márcia pelo telefone (16) 3307-5188 ou pelo e-mail: $\underline{\text { mgrande @ terra.com.br }}$

Agradecemos antecipadamente sua colaboração.

Cordialmente,

Márcia Mazzeo Grande

Doutoranda da Escola Politécnica/USP 


\section{QUESTIONÁRIO}

\section{Bloco 1: Perfil das revendas}

1. A concessionária é:

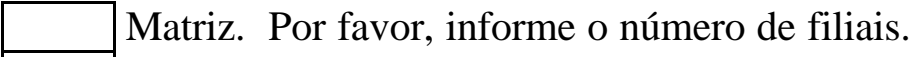
Filial.

2. A empresa é controlada por algum grupo econômico?

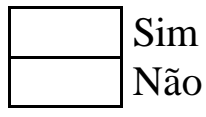

3. Se SIM, o grupo controla revendas de diferentes marcas?

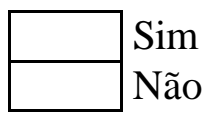

4. Se SIM, especificar:

Marca 1

Marca 2

Marca 3

Marca 4

Número de lojas

Número de lojas

Número de lojas

Número de lojas

5. A empresa possui negócios associados?

\begin{tabular}{|l|l}
\hline & Locação de veículos \\
& Garagem de usados \\
& Outros. Quais
\end{tabular}

6. Por favor, informe:

a) Número de carros novos vendidos por mês

b) Número de atendimento mensais na oficina da revenda:

c) Número dos funcionários da revenda: 


\section{Bloco 2: Estrutura da concessionária}

7. A sua revenda possui um showroom organizado?

$\operatorname{Sim} \square$ Não

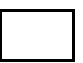

8. Com relação à comercialização de carros usados (Por favor, marque quantas alternativas forem necessárias):

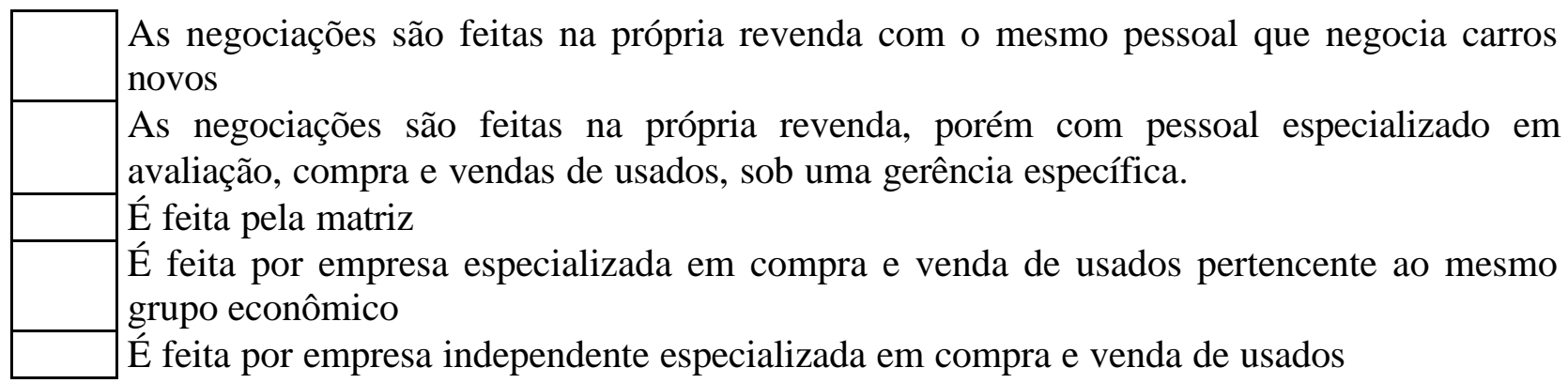

9. Os serviços de funilaria são executados (Por favor, marque quantas alternativas forem necessárias):

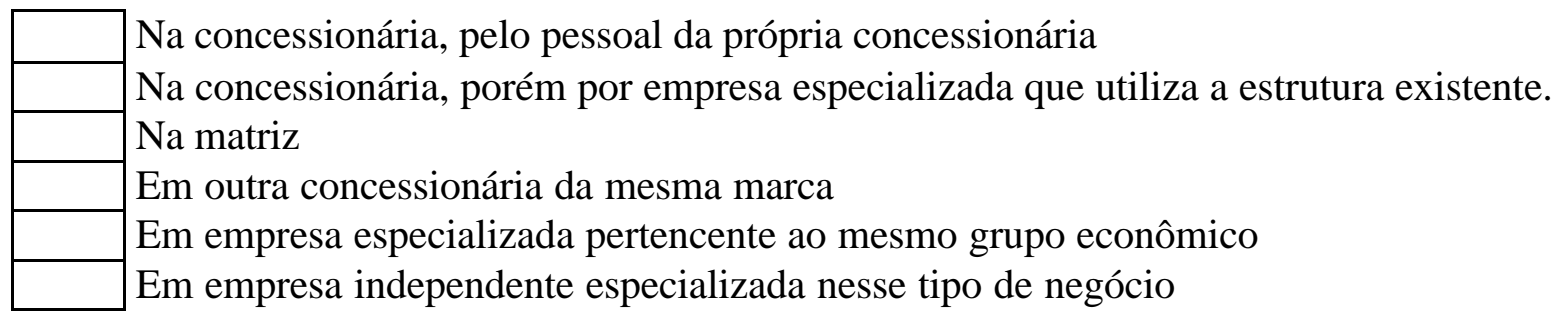

10. Os serviços de oficina mecânica são executados (Por favor, marque quantas alternativas forem necessárias):

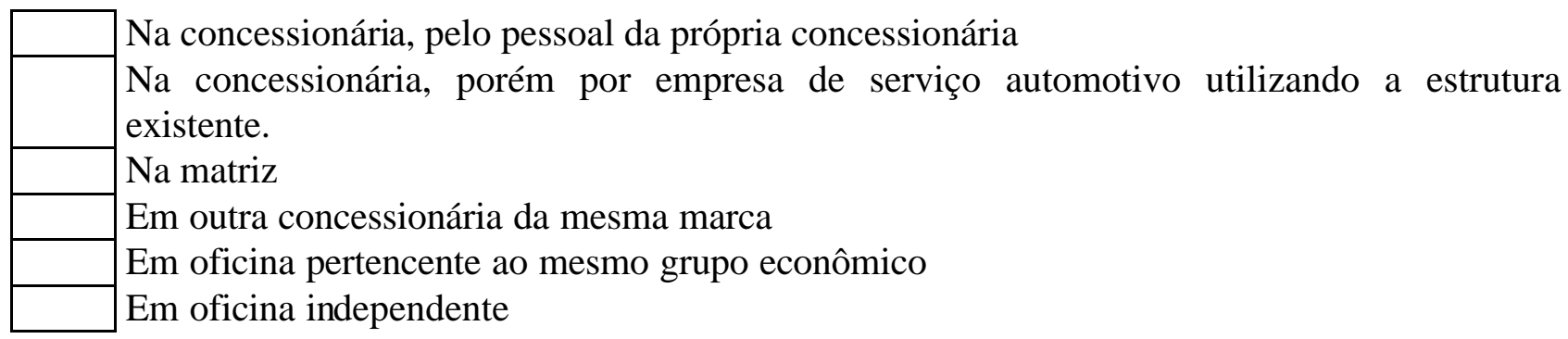

11. Os serviços rápidos (alinhamento, balanceamento, troca de pneus) são executados (Por favor, marque quantas alternativas forem necessárias):

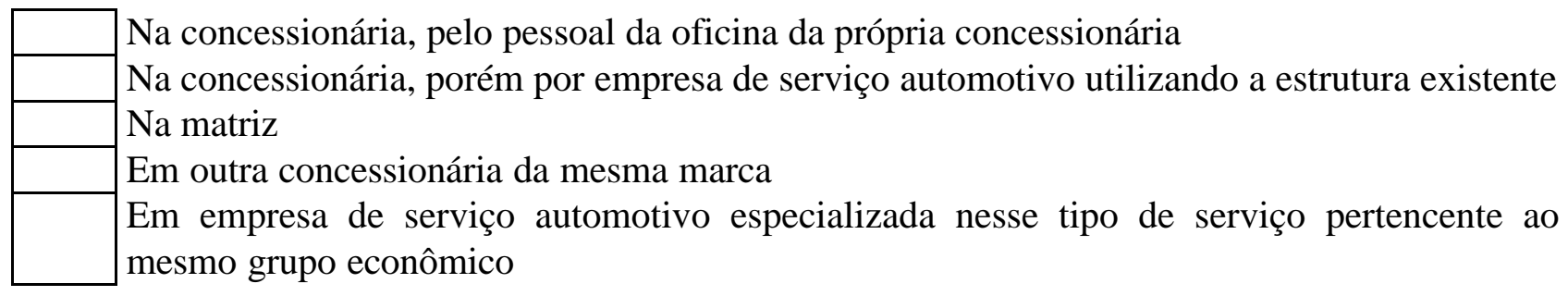


Em empresa de serviço automotivo independente especializada nesse tipo de serviço

12. Responda aos itens $a, b, c$ e $d$ abaixo somente se a sua revenda possui parceiras em pelo menos um dos itens acima: comercialização de carros usados, funilaria, oficina mecânica e serviços rápidos.

a) Em quais terceirizações existem contratos formais regendo a operação? (Por favor marque quantas alternativas forem necessárias)

\begin{tabular}{|l|l}
\hline & Comercialização de carros usados \\
\hline & Oficina mecânica \\
& Funilaria \\
\hline & Serviços rápidos. \\
& Nenhuma
\end{tabular}

b)A montadora participou da formação de quais terceirizações? (Por favor, marque quantas alternativas forem necessárias)

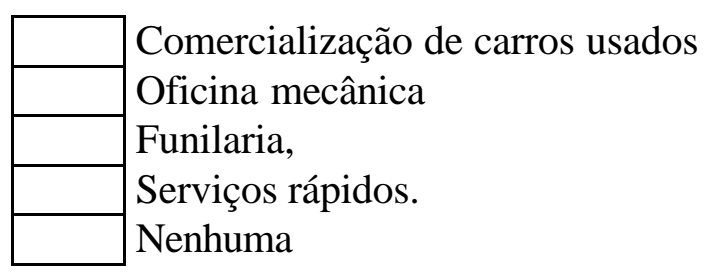

c) Houve resistência da montadora à formação de quais terceirizações? (Por favor marque quantas alternativas forem necessárias):

\begin{tabular}{|l|l}
\hline & Comercialização de carros usados \\
\hline & Oficina mecânica \\
& Funilaria, \\
\hline & Serviços rápidos. \\
Nenhuma
\end{tabular}

d) Indique qual o principal benefício conseguido com a(s) terceirizações(s).

\begin{tabular}{|l|l|}
\hline & Redução de custos \\
\hline & Aumento da qualidade dos serviços \\
\hline & Maior diversificação de serviços \\
\hline & Maior satisfação do cliente \\
\hline & Maior rapidez \\
\hline & Outro. Especifique. \\
\hline
\end{tabular}


14. Se NÃO, as peças são (Por favor, marque quantas alternativas forem necessárias):

Solicitadas a matriz

Solicitadas a um centro de distribuição de peças que serve a várias concessionárias da mesma marca

Solicitadas à outra concessionária da rede

Solicitadas à montadora

\section{Bloco 3: Relação concessionária -montadora.}

15. Indique a ocorrência ou não dos fatores abaixo na relação com a montadora. (Por favor, utiliza o seguinte código: 1 para sim; 2 para em implantação; 3 para não).

a) Reuniões regionais com revendedores e altos executivos das montadoras para serem divulgadas as políticas e decisões sobre a distribuição

b) Comitê de aconselhamento dos revendedores (ou outro mecanismo) onde representantes dos revendedores e executivos chave da montadora se reúnem para discutir os problemas das revendas.

c) Programa específico da montadora para a formação de sucessores das revendas

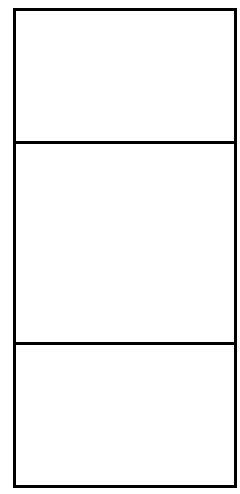


16. Responda sim ou não para as questões abaixo
a) As negociações com as montadoras contam com a presença de altos executivos da montadora
b) As metas de vendas e desempenho específico da revenda são definidos pelo fabricante em conjunto com o revendedor
c) A estratégia de lançamento de novos produtos é definida pelo fabricante em conjunto com os revendedores
d) Os serviços a serem oferecidos são definidos em conjunto pela montadora e pelo revendedor
e) A montadora dá suporte à revenda em áreas como gestão financeira, custos, gestão de estoque, gestão da qualidade, vendas
f) A montadora dá retorno aos revendedores dos resultados das pesquisas de opinião sobre o atendimento que realiza com os consumidores
g) Comparado ao passado recente, a montadora hoje é mais flexível quanto ao sistema de quotas disponibilizando um mix de produtos mais adequado ao mercado local
h) A concessionária pretende continuar representando a montadora no futuro próximo

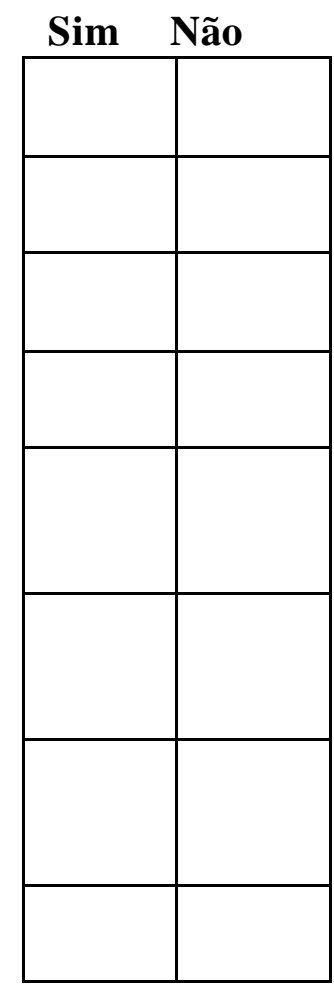

17. A montadora tem exigido (Por favor, responda sim ou não):

a) Padronização da aparência da loja

b) Padronização do processo de venda

c) Padronização do atendimento na oficina

d) Certificação da oficina (ASE, IQA, outras)

e) Certificação da concessionária

f) Treinamento de pessoal

g) Padrão de qualidade de atendimento

h) Uso de software específico para envio de dados do revendedor para a montadora

g) Adoção de programas específicos (certificação de usados, promoções, etc)

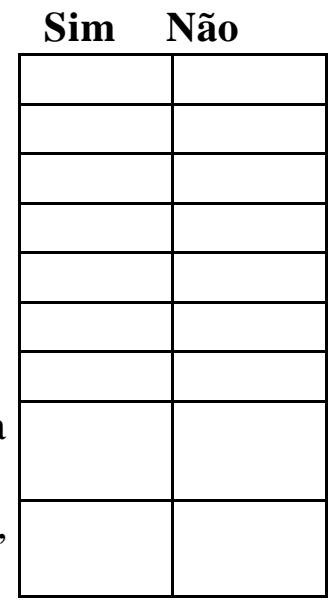

18. Que tipo de incentivo a montadora tem oferecido para a adoção dos itens acima?(Por favor, marque quantos itens forem necessários).

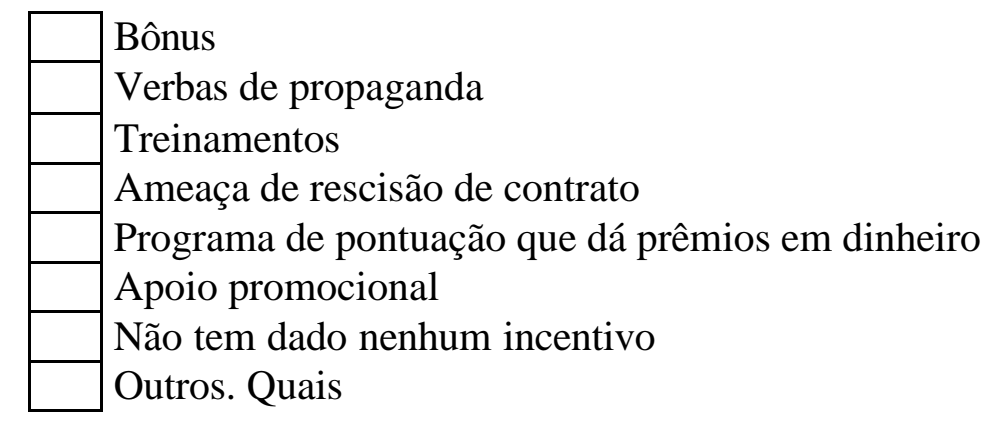




\section{Bloco 4: Inovações nas revendas}

19. A revenda utiliza comércio-eletronico com clientes?

Sim

Não

20. Se Não, há previsão de utilização?

\begin{tabular}{|l|l}
\hline Sim \\
\hline
\end{tabular}

21. Se SIM, que tipos de serviços são oferecidos? (Por favor, marque quantas alternativas forem necessárias).

Busca de carros novos

Busca de carros usados

Informações sobre financiamentos

Agendamento de revisões

Disponibilidade de peças de reposição

Páginas de entretenimento

Vitrine (site de informação sobre os produtos)

Outros. Quais?

22. A revenda utiliza: (Por favor, marque quantas alternativas forem necessárias).

EDI (Troca Eletrônica de Dados)

CRM - Gerenciamento de relacionamento com o cliente (software)

ERP - Sistema integrado de gerenciamento Empresarial

Intranet

Extranet

E-mail interno

Banco de dados

Outras. Quais?

23. Indique o estágio de informatização dos processos abaixo: (Por favor, utiliza o seguinte código: 1 para totalmente informatizado, 2 para em processo de informatização e 3 para nada mudou).

Administração de estoques

Solicitação de compras

Recebimento de mercadorias 
Emissão de documentos de compras

Envio de pagamento

Planejamento de serviços

Controle de serviços

Solicitação de serviços

Obtenção de informações sobre as necessidades dos clientes

Emissão de documento de venda

24. Indique a fase de adoção dos itens abaixo. (Por favor, coloque 1 para totalmente implantado; 2 para em implantação; 3 para sem previsão).

a) Programa de qualidade

b) Programa de satisfação do cliente

c) Programa de fidelização do cliente

d) Programa de capacitação de recursos humanos

e) Implantação de indicadores de desempenho como tempo de espera, retrabalho na oficina

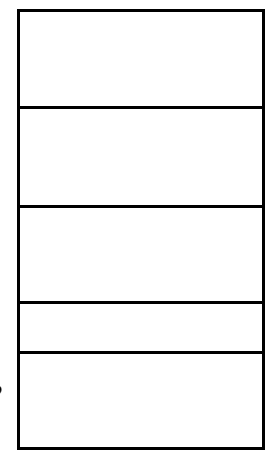

25. Quais formas alternativas de vendas de carros novos a revenda utiliza? (Por favor, marque quantas forem necessárias)

\begin{tabular}{|l|}
\hline \\
\hline \\
\hline
\end{tabular}

Visitas externas

Tele -marketing

Display em shopping center

Feirões

Não utiliza outras formas de venda

Outras. Quais?

26. Assinale os serviços que a concessionária oferece e indique se é ou não terceirizado

\begin{tabular}{|l|l|c|c|}
\hline \multicolumn{2}{|l|}{ Serviço } & \multicolumn{2}{l|}{ É terceirizado? } \\
\multicolumn{2}{|l|}{ Sim } & Sim \\
\hline & Financiamento & & \\
\hline & Seguros & & \\
\hline
\end{tabular}




\begin{tabular}{|l|l|l|l|}
\hline & Licenciamento & & \\
\hline & Lojas de conveniência & & \\
\hline & Garantia estendida & & \\
\hline & Instalação de acessórios & & \\
\hline & Assistência técnica com atendimento mecânico domiciliar & & \\
\hline & Abastecimento cristalização, & & \\
\hline & $\begin{array}{l}\text { Embelezamento } \\
\text { impermeabilização, etc) }\end{array}$ & \\
\hline & Boutique espelhamento, & & \\
\hline & Supermercado de peças & & \\
\hline & Outros. Quais? & & \\
\hline
\end{tabular}

27. A revenda pretende implantar novos serviços?

Não

Sim. Quais

\section{Bloco 5: Sobre o negócio}

28. Quais os principais concorrentes da rede de concessionárias? (Por favor, utilize uma escala de 1 a 5: 1 para concorrência fraca; 5 para concorrência forte)
a) Oficinas independentes
b) Centros automotivos
c) Mercado independente de reposição
d) Sites de venda de carros na Internet
e) Garagistas
f) Seguradoras
g) Montadoras
h) Outros. Quais?

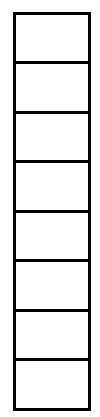

29. Como a revenda vê a venda direta das montadoras pela Internet?

Uma ameaça à sobrevivência da rede de concessionárias no curto prazo
Uma prática que não tem afetado de forma significativa o negócio da revenda
Um bom negócio para a revenda hoje, pois a revenda não investe em estoque e ganha uma
comissão pela entrega do veículo
Uma prática que no futuro poder vir a alterar profundamente o papel da revenda na
distribuição de veículos
Ainda é cedo para fazer uma avaliação sobre a questão
Não se aplica

30. Qual o grau de importância dos aspectos abaixo para a revenda na atualidade? (Por favor, utilize uma escala de 1 a 5: 1 para sem importância; 5 para muito importante.)

Informatização das operações 


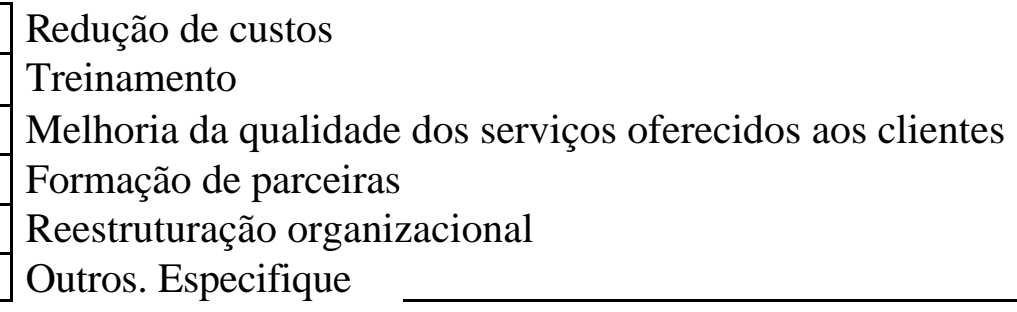

31. Por favor, informe:

a) a participação de cada uma das atividades da revenda na formação do lucro.

\begin{tabular}{|l|l|}
\hline Atividades & \% na formação do lucro \\
\hline 1. Vendas de carros novos & \\
\hline 2. Vendas de carros usados & \\
\hline 3. Peças de reposição & \\
\hline 4. Oficina & \\
\hline 5. F \& I & \\
\hline 6. Outros serviços & \\
\hline
\end{tabular}

b) A rentabilidade do negócio:

\begin{tabular}{|l|l|}
\hline & 0 a 1,5 \\
\hline & 1,5 a 3 \\
\hline 3 a 4,5 \\
\hline 4,5 a 6 \\
\hline 6 a 7,5 \\
\hline Acima de 7,5 \\
\hline
\end{tabular}

AGRADECEMOS SUA COLABORAÇÃO!

\begin{tabular}{|c|c|}
\hline Empresa: & \\
\hline Nome: & \\
\hline Cargo: & \\
\hline Tel. Contato & E-mail: \\
\hline
\end{tabular}

